University of Nebraska - Lincoln

DigitalCommons@University of Nebraska - Lincoln

Agronomy \& Horticulture -- Faculty Publications

Agronomy and Horticulture Department

$1-1943$

\title{
Resurvey of Grasses, Forbs, and Underground Plant Parts at the End of the Great Drought
}

\author{
J. E. Weaver \\ University of Nebraska-Lincoln \\ F. W. Albertson \\ Fort Hays Kansas State College
}

Follow this and additional works at: https://digitalcommons.unl.edu/agronomyfacpub

Part of the Plant Sciences Commons

Weaver, J. E. and Albertson, F. W., "Resurvey of Grasses, Forbs, and Underground Plant Parts at the End of the Great Drought" (1943). Agronomy \& Horticulture -- Faculty Publications. 478.

https://digitalcommons.unl.edu/agronomyfacpub/478

This Article is brought to you for free and open access by the Agronomy and Horticulture Department at DigitalCommons@University of Nebraska - Lincoln. It has been accepted for inclusion in Agronomy \& Horticulture -Faculty Publications by an authorized administrator of DigitalCommons@University of Nebraska - Lincoln. 


\author{
J. E. WeAver \\ University of Nebraska \\ AND \\ F. W. Albertson \\ Fort Hays Kansas State College
}




\section{TABLE OF CONTENTS}

INTRODUCTION

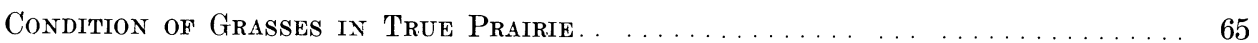

Andropogon scoparius $\ldots \ldots \ldots \ldots \ldots$

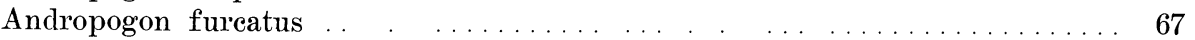

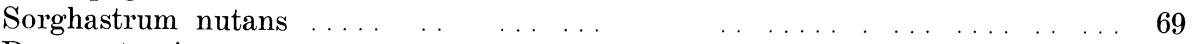

Poa pratensis ....... . . . . . . . . . . . . . . . . . . 69

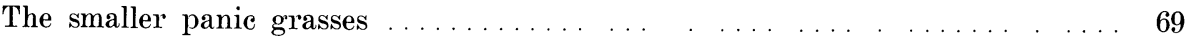

Stipa spartea .................................. 70

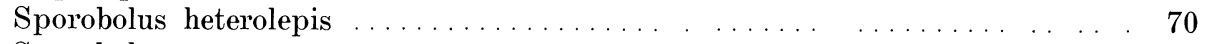

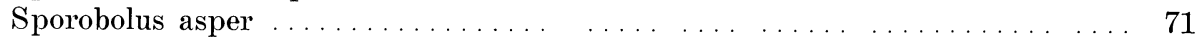

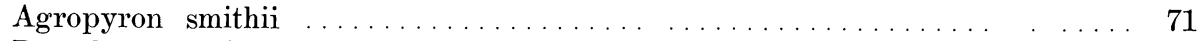

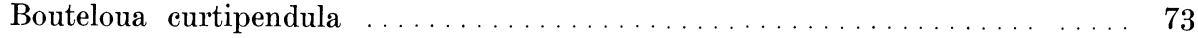

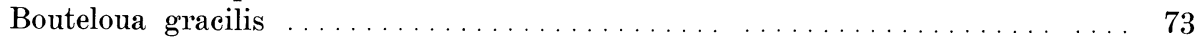

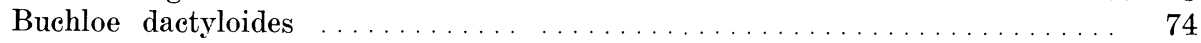

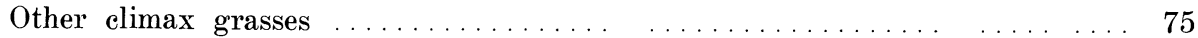

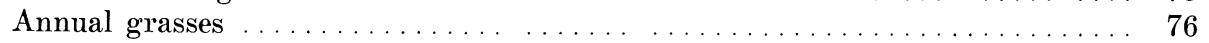

Studies on the composition of plant cover $\ldots \ldots \ldots \ldots \ldots \ldots \ldots$

Condition of Grasses in Mixed Prairie $\ldots \ldots \ldots \ldots \ldots \ldots \ldots \ldots \ldots$

Andropogon scoparius $\ldots \ldots \ldots \ldots \ldots \ldots \ldots \ldots \ldots$

Andropogon furcatus $\ldots \ldots \ldots \ldots \ldots \ldots \ldots \ldots \ldots \ldots \ldots$

Bouteloua curtipendula $\ldots \ldots \ldots \ldots \ldots$

Aristida purpurea and $\mathrm{A}$. longiseta $\ldots \ldots \ldots \ldots \ldots \ldots \ldots \ldots \ldots$

Bouteloua gracilis $\ldots \ldots \ldots \ldots \ldots \ldots \ldots \ldots \ldots \ldots$

Buchloe dactyloides $\ldots \ldots \ldots \ldots \ldots$

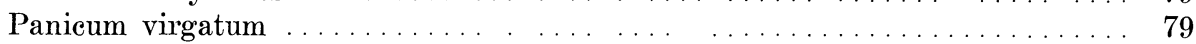

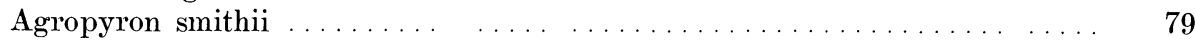

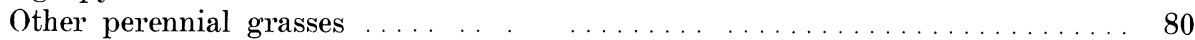

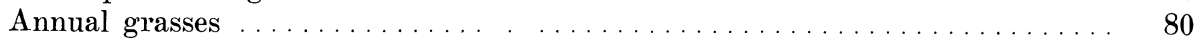

Studies on the composition of plant cover .. $\ldots \ldots \ldots \ldots \ldots \ldots \ldots \ldots$

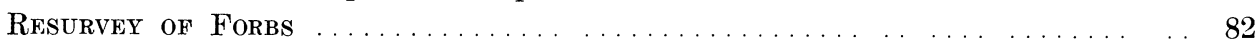

Nature and causes of losses $\ldots \ldots \ldots \ldots \ldots \ldots \ldots \ldots \ldots \ldots$

Comparative number of long-lived species $\ldots \ldots \ldots \ldots \ldots \ldots$

Relative size before and during drought . . . . . . . . . . . . . . . . . 84

Decrease in numbers $\ldots \ldots \ldots \ldots \ldots \ldots \ldots \ldots \ldots \ldots \ldots$

Abundance in $1940 \ldots \ldots \ldots \ldots \ldots \ldots \ldots \ldots \ldots \ldots \ldots \ldots \ldots \ldots$

Abundance in sampling areas $\ldots \ldots \ldots \ldots \ldots \ldots \ldots \ldots \ldots \ldots$

Predrought and post-drought distribution $\ldots \ldots \ldots \ldots \ldots \ldots \ldots \ldots \ldots \ldots$

Resurvey of Underground PlaAnt Parts $\ldots \ldots \ldots \ldots \ldots \ldots \ldots . \ldots \ldots$

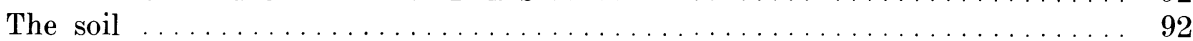

Predrought distribution of roots in true prairie $\ldots \ldots \ldots \ldots \ldots \ldots \ldots \ldots . . \ldots 3$

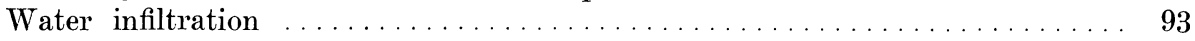

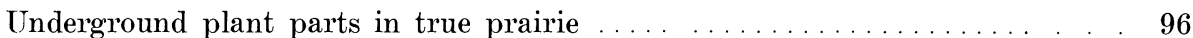

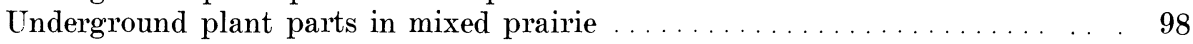

Piant Yield in Relation to Water Content of Soll............... 103

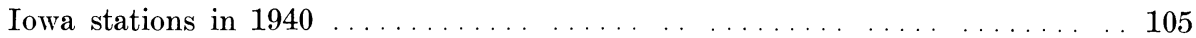

Lincoln stations in $1940 \ldots \ldots \ldots \ldots \ldots$

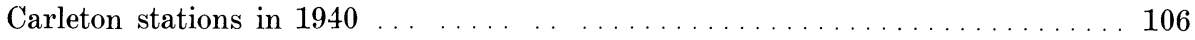

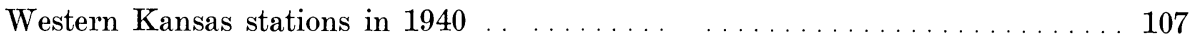

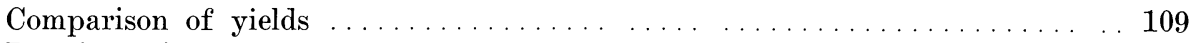

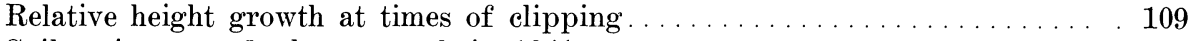

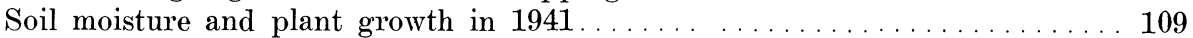

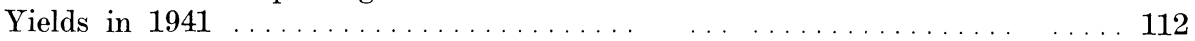

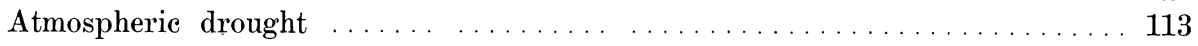

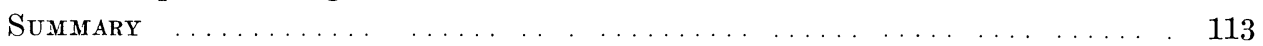

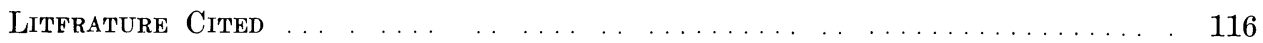




\section{RESURVEY OF GRASSES, FORBS, AND UNDERGROUND PLANT PARTS AT THE END OF THE GREAT DROUGHT'}

\section{INTRODUCTION}

Eight years have now passed since the fateful spring of 1934. The almost rainless March and April, the unusually high winds, and the great clouds of dust following two summers of decreasing precipitation, portended disaster. The intensity and duration of the drought and its appalling destruction have been studied from the beginning (Weaver, Stoddart, and Noll 1935) and several reports have recorded changes wrought in the native grass cover (Savage 1937; Weaver and Albertson 1936, 1939, 1940, 1940a). Drought began in great intensity a year earlier in the mixed prairie westward and southwestward. But previous to 1933, intensive studies had been pursued which gave a clear picture of the composition and structure of the several grassland types (Albertson 1937). Uninterrupted quantitative field studies year after year have traced the further deterioration or improvement of the meager vegetation until the wet year of 1941 finally concluded the dry cycle (Albertson and Weaver 1942).

The higher rainfall, sometimes monthly periods with three times the normal amount, has again moistened the dry soil to depths of normal, predrought root penetration. This, with a return to more normal atmospheric moisture, temperature, and wind movement, has already initiated marked changes in the vegetation. Hence, a resurvey of the condition of the vegetation of true prairie and mixed prairie, including its short-grass disclimax, both above and below ground at the end of the drought seemed advisable. It will conclude the phase of deterioration due to desiccation and at the same time provide a clear and definite background from which the processes involved in the return of vegetation to a new dynamic stabilization may be traced.

Detailed studies in true prairie have been made on 3 large grassland tracts in western Iowa and 12, each of 20 to 180 acres in extent, in eastern Nebraska and north-central Kansas. Nearly all of these have been examined regularly during each of the summer months of each year of the drought. Another group of 12 stations in the western half of Kansas has been similarly studied, although changes in some of them have been recorded for only 4 years. The writers have collaborated closely in all field work and especially on field trips sufficiently extensive to show clearly that the results here recorded apply in general to western Iowa, to much of Nebraska and Kansas (aside from sandy lands), and to the non-sandy soil of the eastern half of Colorado as well (Weaver and Albertson 1940a; Weaver and Mueller 1942) (Fig. 1).

Methods of study consisted of list, chart, clip, and permanent quadrats. Permanent transects and map- ping, exclosures, and extensive trenching for root excavations have been employed. Much attention has been given to the reproduction, migration, and establishment of individual species of grasses and forbs, and considerable experimental work has been done on habits of growth, water relations, and relative drought resistance. Extensive histories of each prairie have been built up year by year and much work in other grassland areas over a wide range of territory has been done. This report will not include the very extensive measurements made on soil moisture and other habitat factors, since most of them have already been published. A comprehensive report on the conditions of growth and yield during the last dry year (1940) and the following wet one $\left(1^{\circ} 941\right)$ is included. For convenience of presentation and because the dominant grasses of true and mixed prairie are often different, their present condition in true prairie will be described first.

\section{CONDITION OF GRASSES IN TRUE PRAIRIE}

In true prairie, vegetation is so greatly disturbed that the general situation will be briefly outlined before the status of individual species is discussed. East of the Missouri River there has been little change and any damage to the vegetation has been almost completely repaired. West of this river the cover varies from small to large patches of almost predrought composition through all stages of deterioration to a condition where large areas of soil are only scantily clothed with vegetation. The undisturbed prairie remnants are often found on northfacing slopes or on low ground but also quite as often on level hilltops, on east or west slopes, or even on those facing southward. Why one portion of an apparently uniform area lost its vegetation by death, why the cover remained intact on the remaining part, and why half of the denuded area was again reclaimed and the other portion left nearly bare are unknown. Much thought and study have failed to reveal the answer in terms of habitat factors either above or below ground. The general course of destruction from upland down the sides of hills and then into ravines has been repeatedly obscrved, but why patches equally exposed were left intact remains unexplained (cf. Robertson 1939).

It has been repeatedly observed, however, that death of plants was directly correlated with depth of the root system, more shallowly rooted species almost invariably being the first to succumb. Vegetation in burned prairies was harmed most. But wherever the stand was more open or the soil poorly protected by

1 Contribution No. 135 from the Department of Botany, University of Nebraska. This investigation was aided by a ican Philosophical Society. 


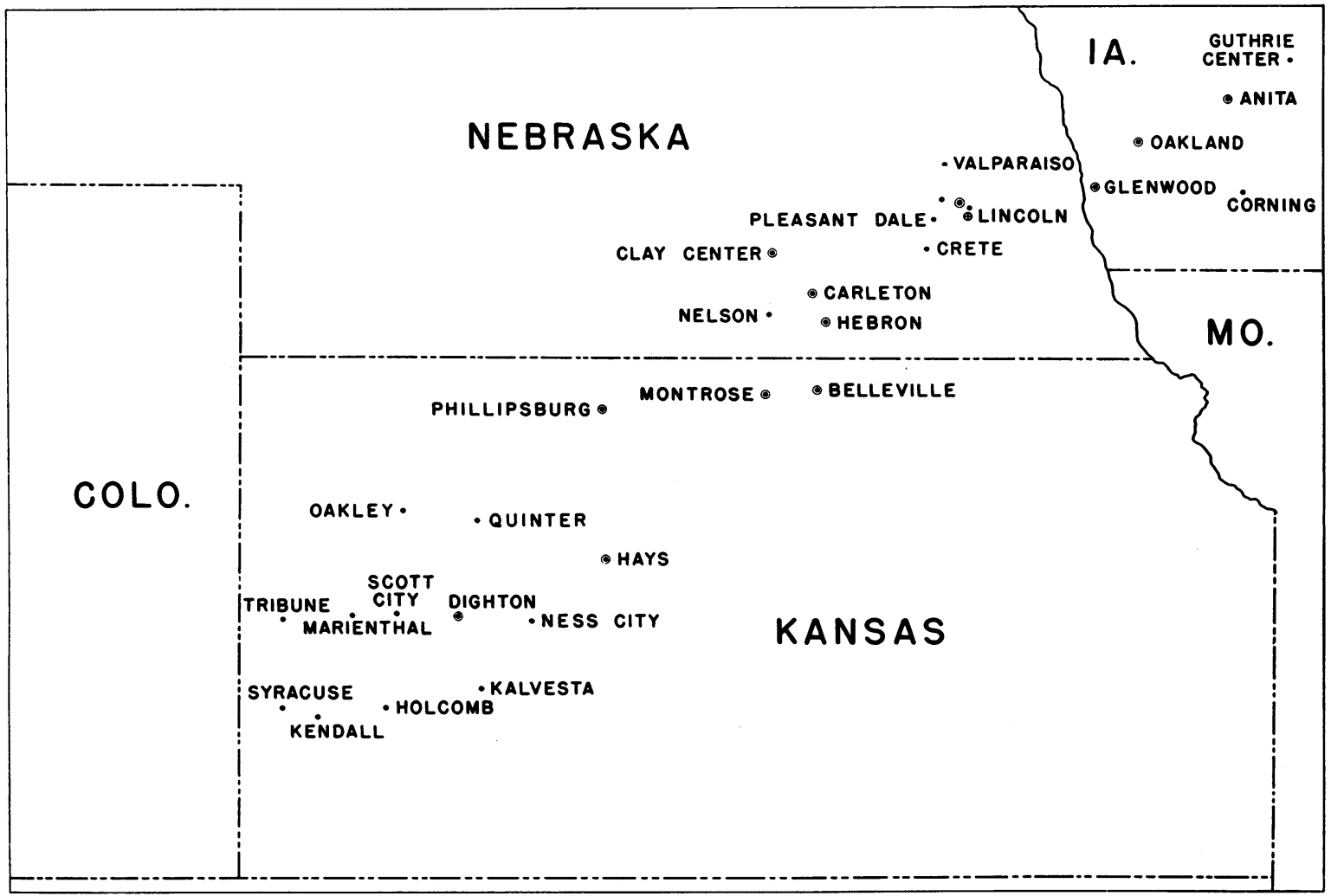

FIG. 1. Map showing location of stations where quantitative studies were made. Stations where water content of soil and plant yields were measured are indicated by a circle and dot, the locations of other stations are shown by dots only.

debris, small centers of bared soil appeared. Thus, the early losses were of the nature of openings in the prairie cover. Where drought was more intense, these open spaces were more abundant and formed a very irregular network of unoccupied soil surface. This openness of cover was greatly accentuated by great destruction to species of the understory. With succeeding years of drought the openings of moderate size often expanded into larger ones. Finally the cover was so decimated that the terrain appeared almost bare, with only the remnants of a former population (Weaver and Albertson 1936).

The spread of certain of the more xeric dominants and the great increase of species previously almost rare have been equally puzzling. Thus, certain bluestem prairies dominated by Andropogon scoparius and $A$. furcatus are now almost entirely covered with western wheat grass (Agropyron smithii). Others are a mosaic of a complete cover of mixed relic bluestems, pure big bluestem (Andropogon furcatus), blue grama (Bouteloua gracilis), western wheat grass, and buffalo grass (Buchloe dactyloides), each type occupying its portion or portions in almost pure stands. Ecotones are so sharply defined that the boundary lines of vegetation have been mapped with plane table and alidade to within a distance of three feet (Fig. 2). The open areas in other prairies with widely spaced plants and nearly bare soil are very irregular in shape and distribution (Figs. 3, 4, and $5)$. The total bare soil in some prairies would exceed by several times the part covered with vegetation. These are being repopulated by diverse species. Mixed communities which will include many dominants will develop for a time at least. Such mixtures constitute the present cover of numerous prairies or

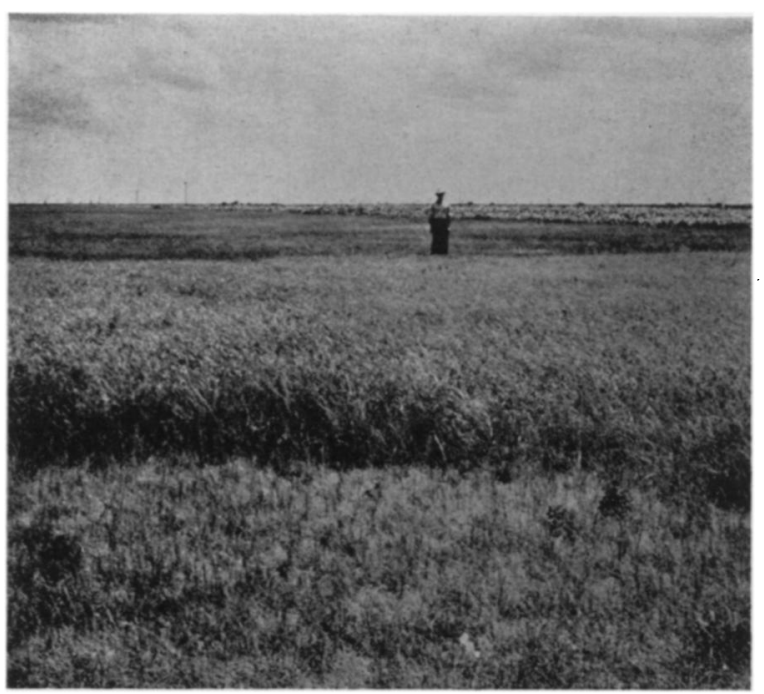

FIg. 2. Three communities of native vegetation with sharply defined boundaries. In the foreground is buffalo grass and beyond is big bluestem. The background is a nearly pure stand of western wheat grass. Carleton, Neb., May 10, 1940. 


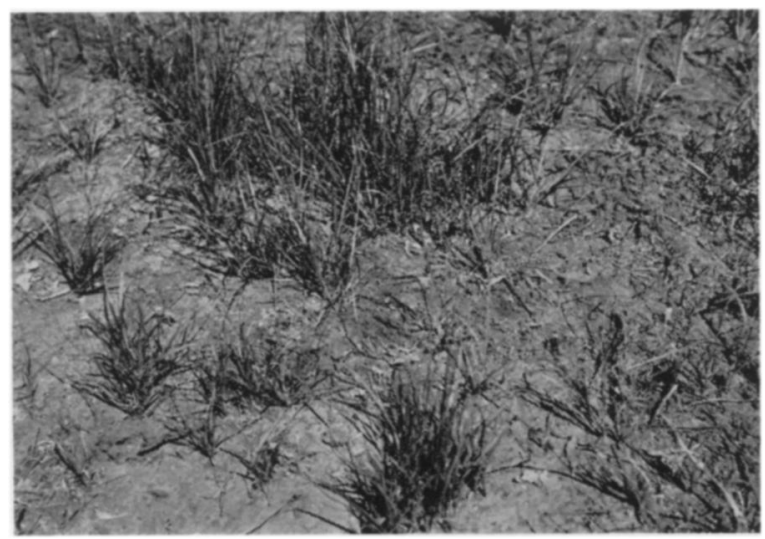

Fig. 3. Bared area caused by drought in early stages of repopulation by blue grama. Valparaiso, Neb., July 8,1938 .

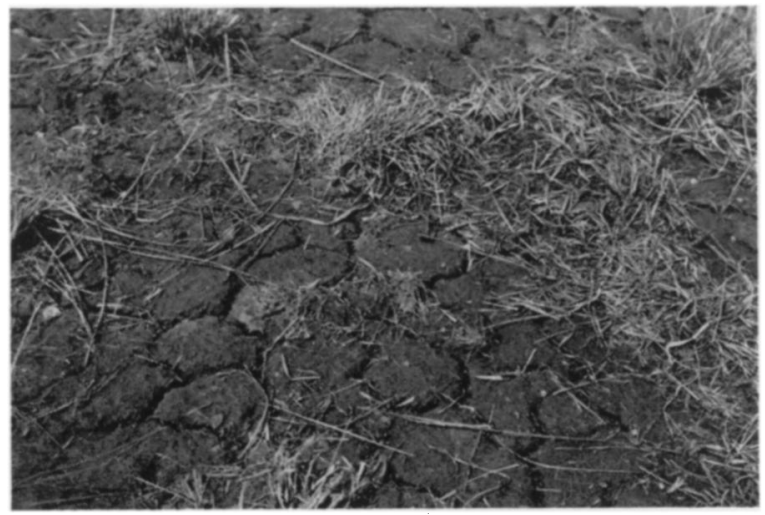

Fig. 4. Bared area in native grassland near Lincoln, Neb., in spring of 1941. Many of the smaller dead crowns of plants have been thrown out of the soil by frost heaving. This condition prevailed widely throughout the midwest after the winter of 1940-1941.

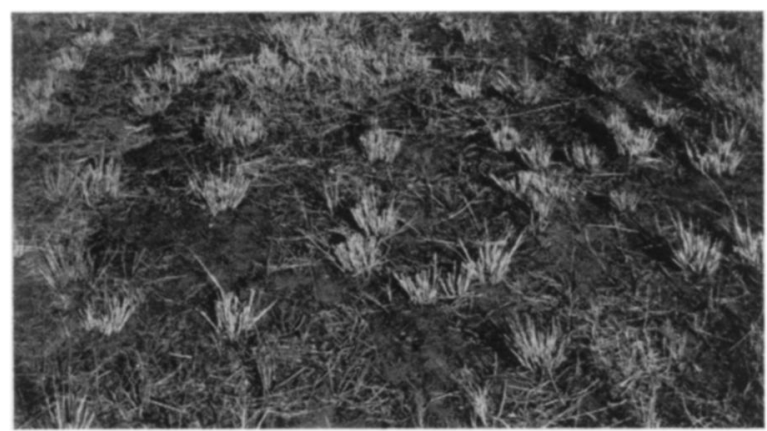

Fig. 5. Soil entirely bared by drought but partially repopulated by 2 - and 3-year-old bunches of needle grass. Such conditions were common during the drought. Photo after mowing, Sept. 29, 1940, near Pleasant Dale, Neb.

the major portions of them. The transect and quadrats in Figure 6 are representative of this condition.

\section{ANDROPOGON Scoparius}

Little bluestem, which was formerly the most abundant of all the prairie grasses, suffered the greatest loss. It is now of only intermediate importance and is outranked by six other species. Scarcely a trace remains in half of the 12 prairies, in others it is rare, and in only portions of two is it abundant. Conversely, in prairies of western Iowa it has maintained its former abundance and in some actually increased at the expense of big bluestem (Fig. 7). Most of the loss occurred the first year of the drought (1934) when great areas with 60 to 90 percent little bluestem alone were laid almost bare. Minor losses of weakened plants continued throughout subsequent years, especially in 1936. There was little or no noticeable recovery. Where the original stands were thinned, they were usually invaded by needle grass (Stipa spartea), prairie dropseed (Sporobolus heterolepis), blue grama, or western wheat grass, or partially repopulated by a spreading of big bluestem and side-oats grama (Bouteloua curtipendula) which formerly accompanied little bluestem.

\section{ANDROPOGON Furcatus}

Although suffering great losses, big bluestem withstood the ravages of drought in a most remarkable manner. Even over the uplands, where it normally formed one fourth or less of the predrought cover, it frequently persisted even if in small amounts where all the little bluestem died. This is believed to be due to its deeper root system which absorbed enough moisture from 2 or 3 feet of moist earth below the level to which the soil was dried (about 4 feet) in 1934. The removal of its competitor (with roots averaging about 4 feet in depth) permitted full use of subsequent rainfall and the actual increase of this rhizomatous grass. At 7 of the 12 stations it is a chief dominant, although confined to certain areas; in the other prairies it remains only in a few very small patches, entirely surrounded by more drought-resisting and aggressive xeric grasses (Fig. 8).

Big bluestem formerly grew in nearly pure stands in well-aerated soil of moist ravines and at bases of slopes everywhere in true prairie. It formed a clearly demarked post-climax vegetation. In the drought region, these tall-grass areas have shrunk greatly in width and at their upper ends, often remaining as narrow belts. Big bluestem has frequently been replaced by western wheat grass, not only on higher land but also on lowlands moistened in part by runin water. In some places whole hillsides of little bluestem and big bluestem prairie have first suffered the loss of the mid-grass, then undergone a thickening of the tall grass into a pure dense stand and finally the complete replacement of big bluestem by blue grama (Fig. 9).

As a final result of the 7 years of drought, big bluestem has lost greatly in the amount of soil it covered, other grasses entirely replacing it over great areas. It occurs irregularly on uplands in nearly pure stands to widely spaced bunches, and has its former percentage mixture with little bluestem in only a few relic patches. Its percentage relation to 


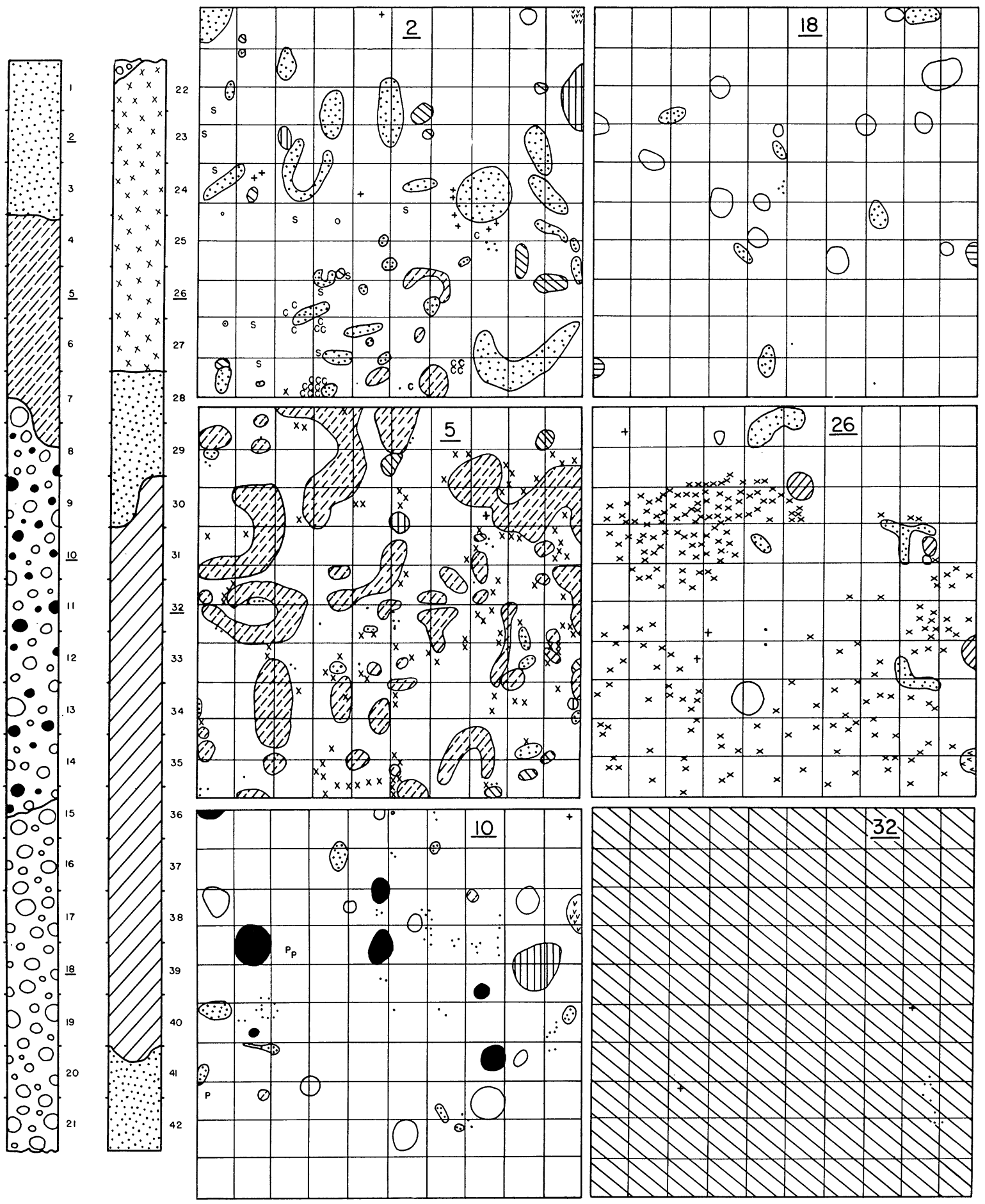

FIG. 6. Transect (left) a meter wide and 42 meters long on a southwest slope in a prairie near Pleasant Dale, Neb. Six distinct types of vegetation are shown. Dots represent big bluestem; broken lines, blue grama; black circular areas, tall dropseed; circles represent bunches of needle grass; $x$, many-flowered aster; and unbroken lines, western wheat grass. Meter quadrats 2, 5, etc. (underscored on transect) are shown on right, where C represents Carex pennsylvanica; P, Poa pratensis; S, seedling Stipa spartea; V, Veronica peregrina; and +, Salsola pestifer. 


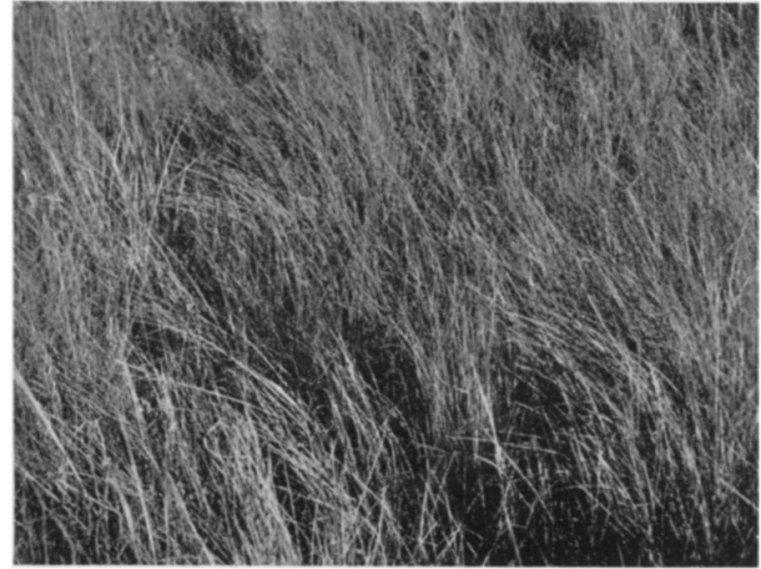

Fig. 7. Pure stand of little bluestem 9 inches tall on north midslope. The soil surface is well protected from beating rains. The surface 4 inches of soil are held intact by many miles of root-fiber per square meter. Anita, Ia., July 22, 1938.

the total remaining but often sparse vegetation, however, is about the same as formerly.

\section{Sorghastrum Nutans}

Indian grass was always a very minor component of big bluestem vegetation on lowland. It also spread through the upland types dominated by little bluestem or needle grass or prairie dropseed very much more sparingly than did big bluestem. It has all but disappeared from uplands, and its distribution on lowland prairies is more restricted than during years of greater moisture supply.

\section{Poa Pratensis}

Kentucky bluegrass was widely and uniformly scattered throughout the true prairie before the drought. It also occurred in native pastures, frequently having entirely replaced the prairie grasses (Weaver and Hansen 1941). It has, with rare ex-

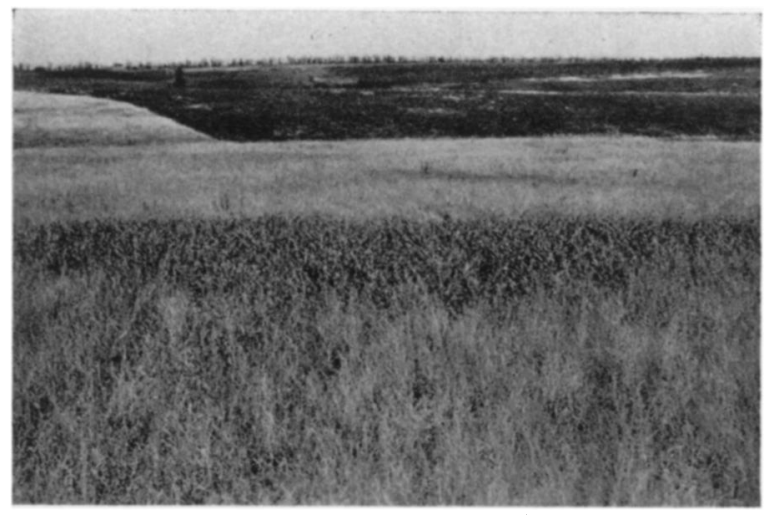

Fig. 8. View of western wheat grass at Montrose, Kan., August 11, 1939. This quarter section was formerly covered with bluestem grasses, only a few remnants of which still remain, such as the darker area in the foreground. On July 5, a prairie fire burned the dried grasses from the blackened area on the right. ceptions, entirely disappeared from pastures and also from portions of prairies where the general cover was greatly damaged. But the shade provided by grasses and forbs elsewhere enabled it to survive in small amounts (Fig. 10). By very early growth in spring, dormancy during midsummer, and vigorous development during autumn, bluegrass had been able to profit from the early spring and often late autumnal rainfall even of dry years and has thereby recovered in part. Although still absent from most of the prairies, and always from those portions invaded by western wheat grass or blue grama, in others it is plentiful in ravines and on less xeric slopes. In a few instances, it spread widely at heads of ravines onto adjacent drought-swept gentle slopes, where it is now the dominant. Generally, it is absent. Where present, its place in the cover (formerly

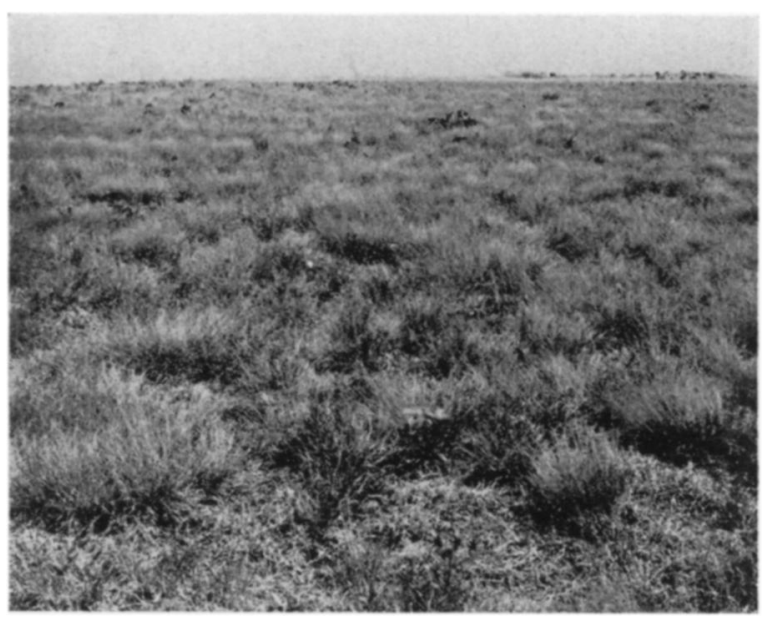

Fig. 9. This north-facing hillside near Hebron, Neb., was a bluestem prairie, chiefly Andropogon scoparius, before 1934. After the death of little bluestem, big bluestem greatly increased in abundance but died from drought after 1937. Thriving bunches of blue grama were firmly established everywhere when photographed in 1940 .

about 5 percent of the basal area) is that of a much thinned post-drought stand. Only in the relic bluestem areas is its normal state of an adapted interstitial species maintained.

\section{The Smaller Panic Grasses . .}

Several species of low-growing panic grasses, chiefly Panicum scribnerianum and $P$. wilcoxianum, were found very widely distributed. In about a third of 335 meter quadrats they occurred in amounts averaging about 0.4 percent of the basal cover. They were the most abundant grasses of the understory. With the opening of the cover and exposure of the lower layer to direct insolation and drying winds these grasses, like most members of the ground layer, almost entirely disappeared. For a few years they were seen rarely and even now they are absent from 8 of the 12 prairies and occur in the others far less often than formerly. 


\section{Stipa Spartea}

Distribution of needle grass before the drought was far less uniform than that of bluestems and many other grasses. It did not occur at any of the 6 most southwesterly stations, which is typical of its general absence in that area. But at the 6 eastern Nebraska stations the needle grass type of consociation was prominent and distinctly localized to hillcrests and dry slopes. Elsewhere it was represented, if at all, only as isolated bunches or patches in the other (usually little bluestem) types.

Needle grass, especially the oldest plants and the younger and hence more poorly rooted bunches, at

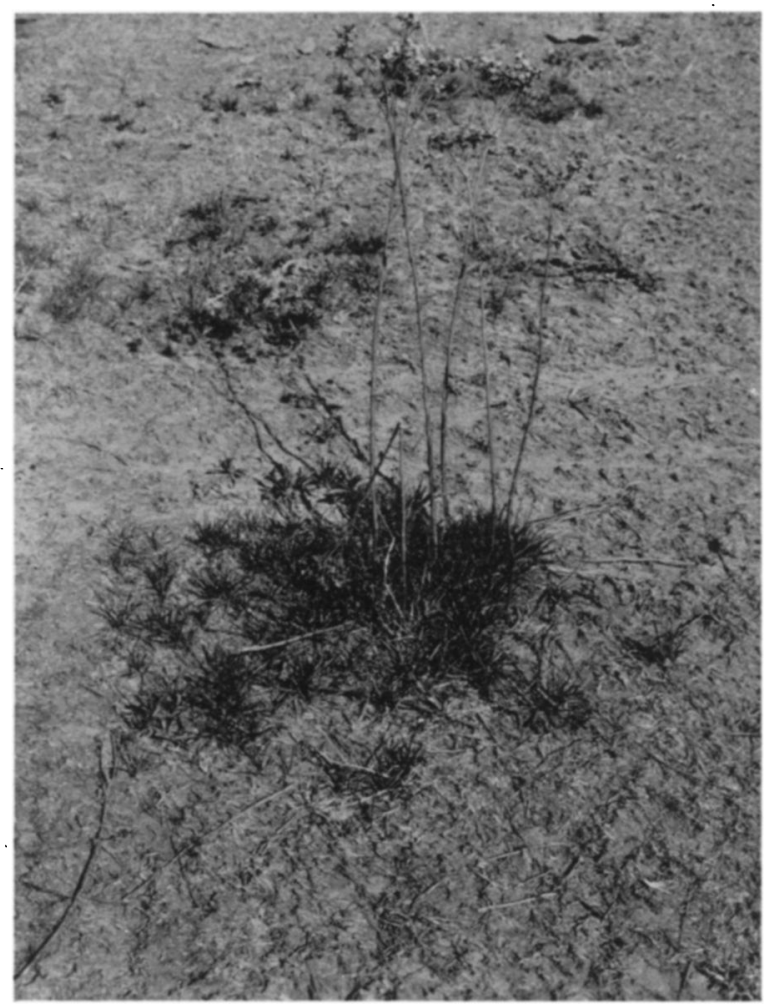

Fig. 10. Tufts of Kentucky bluegrass surviving as a result of shade produced by a small clump of ironweed (Vernonia baldwini) in a native pasture degenerated to bluegrass. April 20, 1935.

first suffered greatly from the drought. Perhaps half the plants were killed. But once the survivors extended their roots into the new territory made available to water absorption by the thinning of the stand, their resistance to drought was greatly increased.

Needle grass renews growth early in spring, attains full development and ripens seed late in May in dry years. Then, by semidormancy, it evades the drought of summer but develops vigorously, if water is available, even late in fall. Almost every year some seed ripened, and during years of least drought it was produced in abundance.

A continuous spreading of this species has taken place into bared or semibared areas regardless of

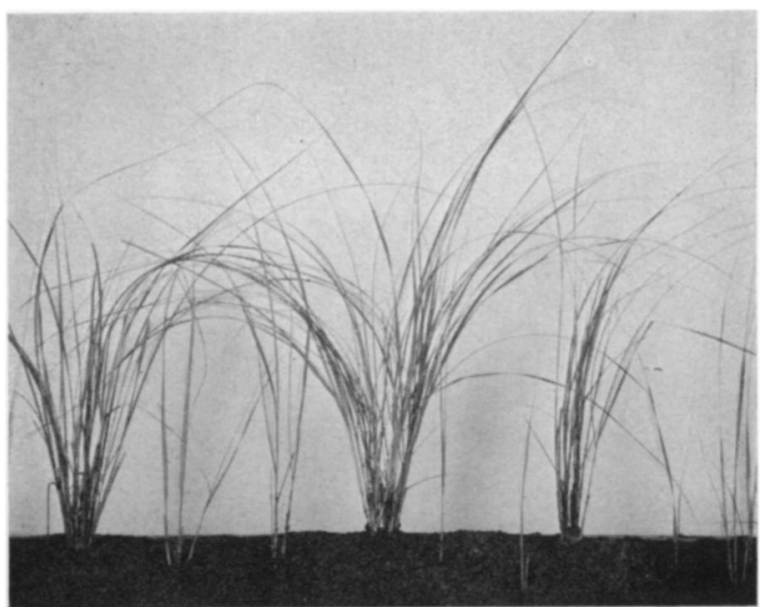

Fig. 11. Young plants of needle grass 1,2 , and 3 years old, transplanted from prairie into soft soil for photographing in August, 1939. The largest bunches are about 1.5 inches in diameter at the base and 14 inches tall.

slope and even onto low ground. Seedlings from the deeply planted seeds have developed in abundance and many have survived. The single or few culms of first-year seedlings developed into a small bunch the second year and into a still larger one the third (Fig. 11). These clearly indicated the forward movement into territory formerly unoccupied by this species, the degree of aggregation, and the time relations as well. Today the new stands of needle grass occupy 5 to 10 times the area of the old ones, which are still extant. The vigorous early absorption of the meager available water supply by this species during drought has distinctly handicapped most other plants in these areas (Fig. 12).

\section{Sporobolus Heterolepis}

Prairie dropseed, like needle grass, did not occur at the most southwesterly group of true prairie stations. At the remaining stations, as over the true prairie generally, this type was more limited in dis-

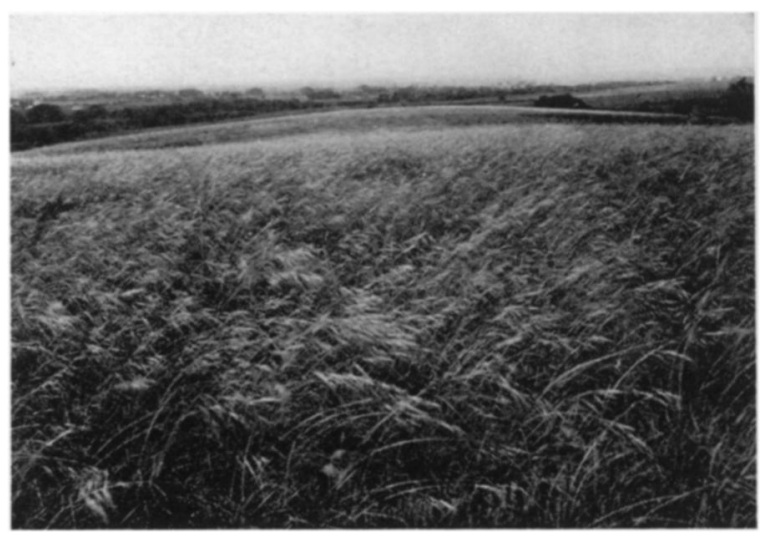

FIG. 12. Little bluestem prairie greatly injured by drought and naturally reseeded to needle grass. June 16, 1941 . 
tribution than needle grass. But both large and small areas dominated by this dropseed in remarkably pure stands were available for study.

Early losses from drought were even higher than those of Stipa spartea, sometimes exceeding 85 percent. It seems probable that this late-blooming bunch grass had been greatly handicapped throughout the years by mowing during September before the seeds had ripened. During several of the years of drought, yield of grasses was so light that the prairies were unmowed or they were sometimes mowed in midsummer when the foliage began to wither. Under either treatment and in protected experimental areas the

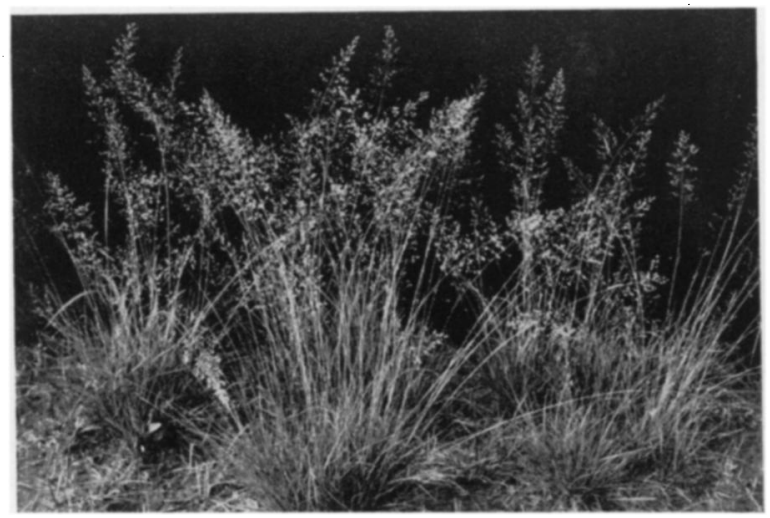

Fig. 13. Bunches of prairie dropseed in early fruiting stage on September 5. Flower stalks are about 30 inches tall. Bunches are of only moderate size.

large seeds of this xerophyte were frequently produced in great quantity. Much soil, bare or only scantily covered with short-lived annual grasses and forbs, was available for occupation. Here prairie dropseed spread rapidly and has now become fully established in nearly pure stands. Increase has amounted in some prairies to 10 or more times the original area occupied, but elsewhere a heterogeneous mixture of widely spaced bunches of this species with those of needle grass, big bluestem, or mats of blue grama, and clumps of tall dropseed (Sporobolus asper) occur (Fig. 13).

\section{SPOROBOLUS Asper}

Tall dropseed was frequently a constituent of prairie vegetation, the plants or small bunches, if present, usually occurring as scattered individuals. It is a xer.c grass which readily increases in abundance even in dry soil. Hence, its great increase in wide areas open to invasion as a result of drought was expected. It is now present at least sparingly in all of the prairies and abundantly in some. The bunch habit, mid-grass stature, erect, persistent flower stalks, and long-enduring, bleached, fibrous leaves, make it a conspicuous feature of the landscape (Fig. 14). Although it has increased greatly, especially in the most disturbed prairies, it is still among the least important of the $\mathbf{1 0}$ grasses of highest rank.

\section{Agropyron Smithit}

Western wheat grass has made a phenomenal increase from a species of very minor importance to one of first rank. It alone has almost complete control of 3 of the 12 prairies, occupies about half of 5 others, and covers a third to a fifth of the remainder. The areas can be stated definitely since this sodforming species is usually found in practically pure stands. Immediately after 1934, this wheat grass became increasingly abundant in prairies and native pastures. It has continued its spread over all types of terrain wherever bared places or open stands of other grasses had resulted from the terrible drought. Long, narrow belts of western wheat grass around the brows of hills indicated where early drought was most severe. Often the whole hillside was rapidly

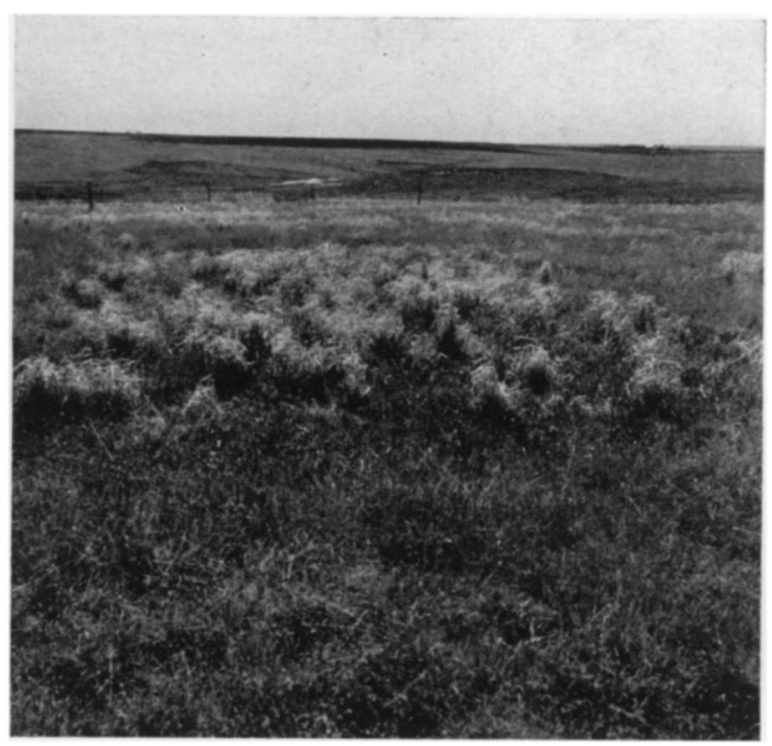

Fig. 14. Bunches of tall dropseed in drought-damaged prairie on May 25, 1939. These grew the previous year but have maintained their ereet form and ileached leaves over winter.

covered with a pure stand of this grass. Many lowlands, once occupied by big bluestem, are a continuous sea of undulating wheat grass. Seed was spread widely by wind and rodents. From newly established centers or along the edges of areas already invaded, slender, much-branched rhizomes 2 to 4 feet long grew rapidly during favorable times through the bared, mellow soil. During years with good spring and early summer rainfall great gains were made. A dry spring resulted in smaller advanees of the invader. It is now found almost everywhere, regardless of soil, slope, or exposure. The on!y necessary conditions, aside from the presence of seed, seem to be those of weakened vegetation and unoccupied soil (Fig. 15). Only once has wheat grass been observed invading stabilized bluestem prairie.

At first the new stands are thin but the stems are tall and heading is profuse. In a year or two the culms thicken to dense stands of 1,000 to 1,300 per square meter, each unit area being occupied by many 
miles of roots and rhizomes. Dwarfing of the foliage and scarcity or absence of spikes indicate at once the low supply of soil moisture and the clue to the wilting, dwarfing, or death of relic bluestems and other less xerie grasses and forbs. Thus, the threading of the rhizomes between the bunches of relic vegetation, indicated by the widely spaced new stems of wheat grass, foreshadowed its final destruction where drought continued. Blue grama and, in a lesser degree, side-oats grama are not ousted by the invader. Neither is needle grass successfully invaded.

The early growth of both western wheat grass and needle grass and consequent depletion of soil moisture by transpiration are important factors in their spread during drought. An experiment to compare rate of water loss from small areas of little bluestem, wheat grass, and needle grass was performed early in the spring of 1941 . Circular pieces of undisturbed sod 18 inches in diameter and 10 inches

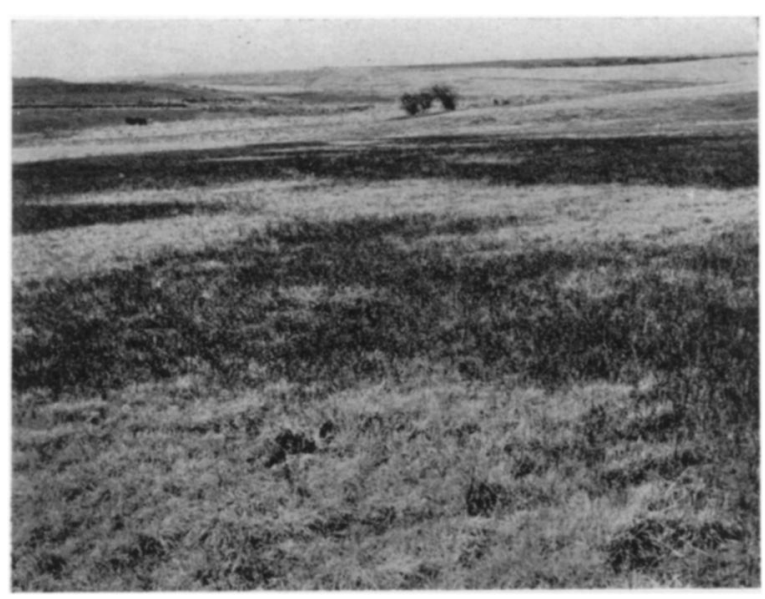

Fig. 15. Alternes of western wheat grass in unmown little bluestem prairie at Hebron, Neb., on May 10, 1940 , before o her vegetation had made much growth.

deep, with natural cover undisturbed, were transferred in pairs into 6 galvanized iron containers 2 feet deep. These had previously been partly filled with moist, compacted prairie soil, so that when the sods were firmly in place they entirely filled the containers to within 2 inches of the top. Containers were weighed March 25 and placed out-of-doors in a frame of 2-inch planks, with insulation between them and the frame. Rainfall was measured and enough extra water added at subsequent weighings as needed to maintain conditions favorable to growth (Fig. 16). The results are shown in Figure 17.

Loss of water by transpiration and evaporation from the soil surface was much less from the bluestem which began growth at its normal time, about April 15. The late spring delayed growth of western wheat grass and needle grass at least two weeks. But despite this, total loss from each of these grasses (86.65 and 90.15 pounds, respectively) was more than twice as great as the 41.55 pounds from little bluestem. Similar field experiments by R. J. Weaver (1941) the preceding spring gave similar results.

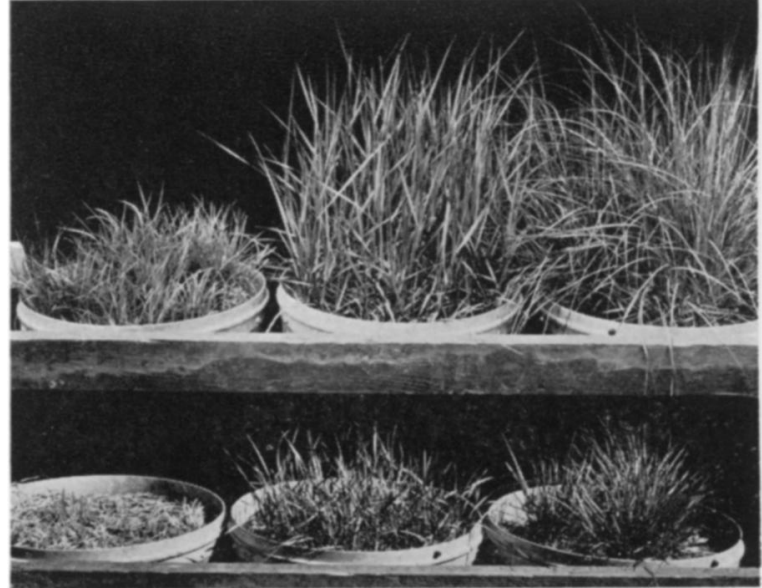

Fig. 16. (Lower) Development of grasses on April 25. New shoots of Andropogon scoparius (left) average an inch in height but only half of the sod is green. Western wheat grass (center) is 7 inches tall and in the fourth-leaf stage; needle grass (right) likewise is growing rapidly.

(Upper) Development on May 20. Little bluestem is only 6.5 inches tall; western wheat grass is 20 inches high and in the eighth-leaf stage; the spikes are just appearing. Needle grass has some flower stalks well developed and the awns of the fruits are emerging from the sheath.

Grasses with rapid development in early spring and with early maturity evade midsummer drought. These same grasses grow vigorously in autumn even after most others are mature and the foliage often no longer green. Clearly, late-appearing grasses are at a great disadvantage and may succumb, when

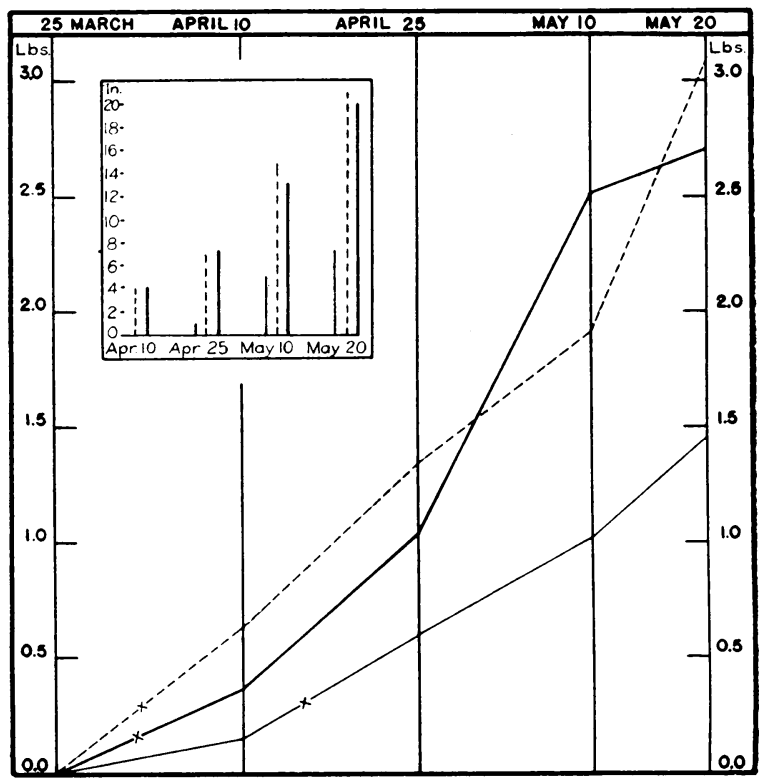

Fig. 17. Average daily loss in pounds per container of Agropyron smithii (heavy line), Stipa spartea (broken line), and Andropogon scoparius (light line), during the spring of 1941. Date of renewal of growth is indicated by $X$. The insert shows average height of grasses on the several dates indicated. 
summer rainfall is very light, from lack of soil moisture used by competitors with different growth habits.

It has been shown elsewhere, as a result of many experiments, that under a cover of wheat grass the rate of infiltration of water into the soil is slow. It averaged 2.4 times as rapid in bluestem prairie as in western wheat grass a few feet distant (Weaver 1942).

\section{Bouteloua Curtipendula}

Side-oats grama is a very drought-resistant grass. It often persisted where all other mid-grasses succumbed. It usually has the appearance of a bunch former, but its abundant rhizomes which are 2 to 4 inches long enable it to spread rapidly. Moreover, it is a prolific seeder, and its range of habitat from moist to dry sites is very wide. Only a grass with such characteristics could increase so rapidly, even if widely and uniformly distributed, from its predrought abundance of only about 0.5 percent of the basal cover to a species of the first rank (Fig. 18).

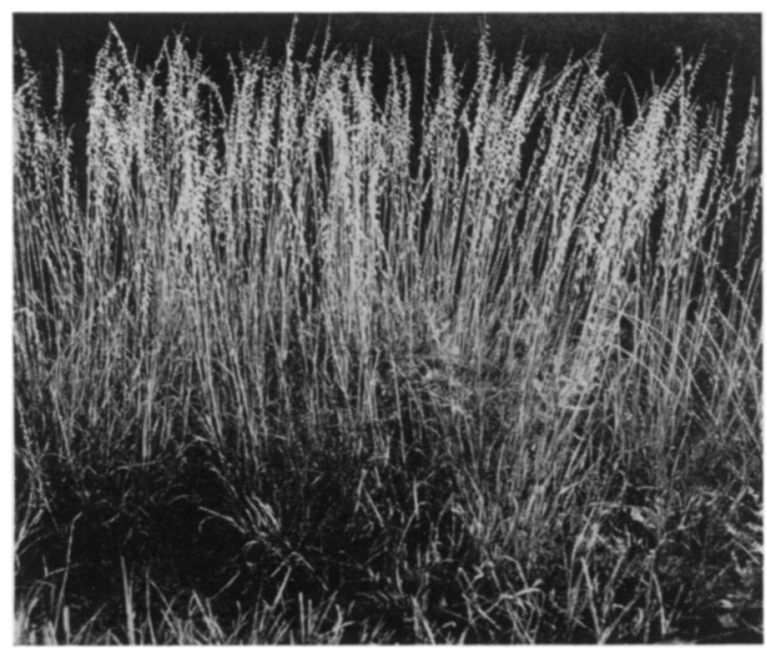

Fig. 18. Representative bunches of a stand of sideoats grama which covered much bared ground following the early years of the great drought. "The plants are about 3 feet tall. Nelson, Neb., Aug. 12, 1937.

Approximately one fifth to one third of the vegetation at most of the 12 prairies consists of this species, except in the portions dominated by western wheat grass, and even in wheat grass prairies it is prominent during years with at least moderately good rainfall.

Side-oats grama is fully as important as needle grass, with which it is intermixed, but it rarely shows such a high degree of dominance as this species. It is far more widely distributed throughout the prairies than is needle grass and has replaced little bluestem to an even greater extent than has big bluestem. In certain prairies it has attained the rank of the leading dominant, and over considerable areas where bluestems were killed by burial under dust it grew during the most favorable drought years in pure dense stands. In fact, it seems to have over- drawn on the water supply and suffered from drought in consequence. In some places it was severely handicapped by disease (Fowler and Weaver $1940)$.

In many drought-swept prairies, increase of sideoats grama occurred synchronously with the spreading of western wheat grass into the bared areas or into stands of relic big bluestem. The following years witnessed the death of big bluestem but only the suppression of side-oats grama during dry summers. When rainfall in early spring was adequate for good growth but early summer was dry, wheat grass thrived. When early spring was dry and late spring and summer moist, side-oats grama flourished even in a thick stand of wheat grass. In many local areas it has almost replaced its competitor; in others, the reverse is true, while elsewhere almost equal mixtures of these two dominants prevail.

In native pastures, mixed pasture types in the Dakota-Nebraska-Kansas area have resulted from the great increase in side-oats grama and an eastward spreading of sand dropseed (Sporobolus cryptandrus) and western wheat grass. These grasses are often intermixed, especially side-oats grama with sand dropseed or western wheat grass, or each of the three species may dominate different portions of the same pasture.

\section{Bouteloua Gracilis}

Blue grama is now so abundant and has spread so widely that its great gains can be appreciated only by comparison with its former limited occurrence. In 1934, Weaver and Fitzpatrick described it as "sometimes found on thin soils on brows of the steeper hills, especially the xeroclines, occasionally on much eroded, steep slopes bordering ravines, ... in the drier parts of the [true-prairie] region. Here it may occur only as scattered tufts or it may dominate local areas. Its increasing abundance in the understory in undisturbed grassland is an indication of the proximity of the mixed prairie." Little wonder that with death or thinning of its mid-grass competitors and the impact of a Great Plains climate for a period of years over the western edge of true prairie, this dry-land species flourished (Fig. 19). Blue grama is the most drought-resistant of all the native grasses of the Nebraska-Kansas-Colorado region (Mueller and Weaver 1942). It has been more widely and more consistently represented by seedlings and especially seedlings that survived than any other species (Weaver and Mueller 1942). It has often survived where all other grasses have died and repopulated the adjacent bared areas with abundant seedlings (Figs. 3 and 20).

Blue grama spread promptly following the initial drought, since it was harmed the least of all species. Wind and surface water carried the seeds down the slopes and by intermixing them with soil aided in their planting. In this way new centers of distribution were started. By means of peripheral growth from old and new clumps, territory was gained even during years so dry that most grasses merely sur- 


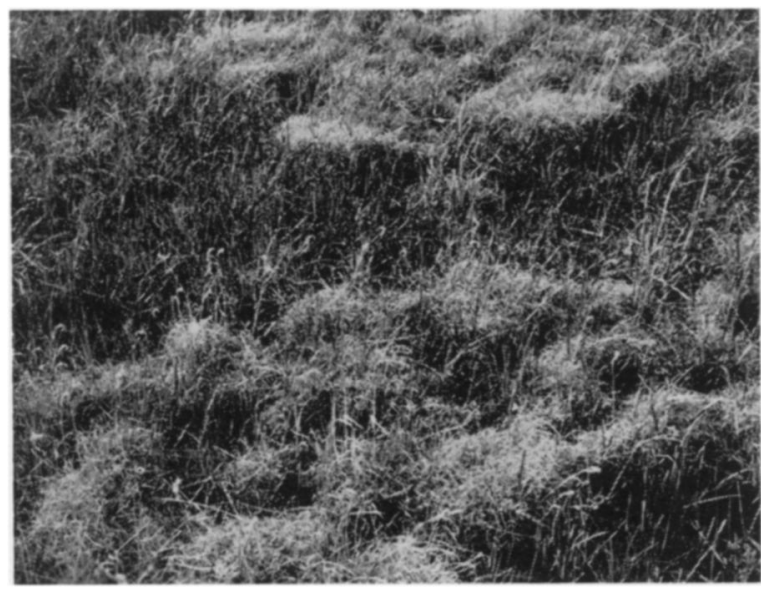

Fig. 19. Invasion of blue grama (light color) into territory occupied by drought-depleted little bluestem. Unmown prairie at Lincoln, Neb., April 29, 1939.

vived. Hence in the grasslands today, patches of blue grama both large and small are to be found anywhere except where the original cover of mid grasses prevailed. Small patches have often become very large and transitions from this short grass to mid grasses or even to the tall big bluestem are often sharp.

Conversely, pioneer tufts and isolated young sods may occur among widely spaced relic or young bunches of tall dropseed, needle grass, big bluestem, or side-oats grama-in fact among any species that remained or has become established in these broad areas ravaged by drought. Such a mixture would not have been understandable in the years before this eatastrophe.

During a period of 5 years, flourishing stands of wheat grass have been gradually replaced where blue grama seedlings became well established (Fig. 21). This was a process of gradually thinning the stand as the many centers of blue grama slowly became

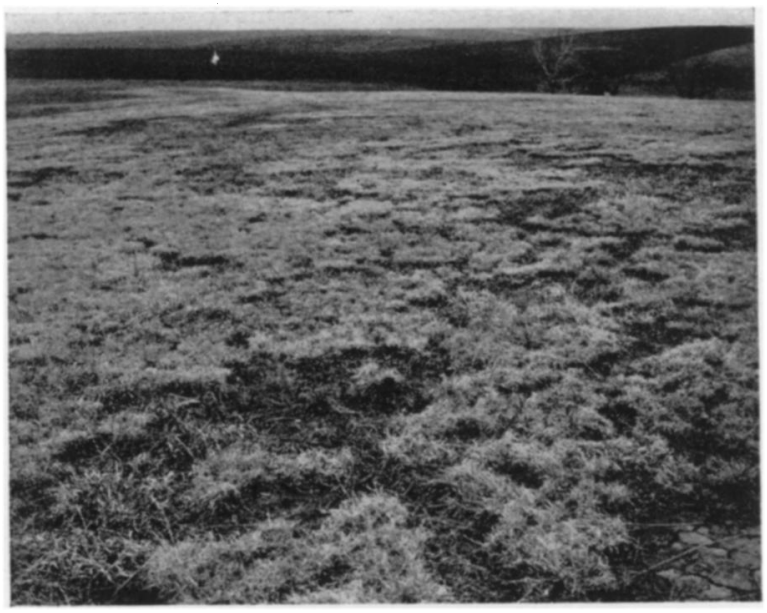

Fig. 20. Extension of blue grama from a few parent clumps to form a more or less continuous cover on hilltop and upper slopes at Valparaiso in eastern Nebraska. April 15, 1941. larger and finally merged and formed an almost complete cover. The short grass has a much finer root system than that of western wheat grass and it more thoroughly occupies the soil, especially near the surface. This grass also has the great advantage of growing vigorously at any time during the warm season, regardless of previous seasonal activity. Its flower stalks can develop, blossoms appear, and seeds ripen in only a few weeks. Hence, it successfully invades pure stands of western wheat grass.

Conversely, old stands of blue grama have been invaded in favorable years by western wheat grass. This produced a type of mixed prairie very common before the drought, especially northwestward. By this invasion a more or less stable community of midand short grass has now been formed, especially in native pastures. This type had no former place in true prairie and its spread, often in combination with buffalo grass, eastward to within 40 miles of the Missouri River is a direct result of the marked arid phase of the climatic cycle.

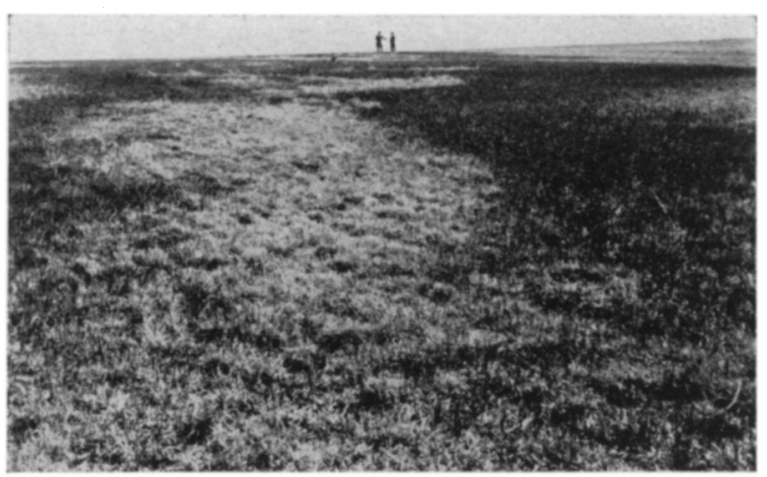

Fig. 21. This entire area at Hebron, Neb., was occupied by bluestem grasses in 1934. As a result of drought and drifting dust they were replaced by western wheat grass by 1936. Much of the wheat grass was, in turn, replaced by blue grama by 1940 . May 10, 1940; dark areas are wheat grass and light-colored patches blue grama.

\section{Buchloe Dactyloides}

Buffalo grass was far less abundant than blue grama before the great drought. It occurred sparingly, sometimes in pure, dense mats of limited extent in ravines but was more usually associated with blue grama on the thinner upland soils. It survived the drought much more poorly than blue grama. It occurs in the 6 westerly prairies, but in 3 only sparingly. In the other 3 it has spread widely, sometimes in pure stands but more often intermixed with blue grama. Many of the more open stands have been invaded by western wheat grass and have become mixed prairie locally (Fig. 22). Perhaps the mellowing of the surface soil by freezing and thawing, following the opening of the plant cover by drought, has been unfavorable to its spread. In native pastures half bared by trampling, it has made great gains and now often elothes the soil with nearly pure stands, thus presenting vegetation of the Great 
Plains disclimax far into true prairie. Of course, this occurred even before the drought, but shortgrass pastures along the western margin of true prairie have greatly increased in numbers and in total area. They occur as far eastward as the Big Sioux River in South Dakota and are also found in extreme southwestern Minnesota. In southern $\mathrm{Ne}$ braska they are common to within 40 miles of the Missouri River.

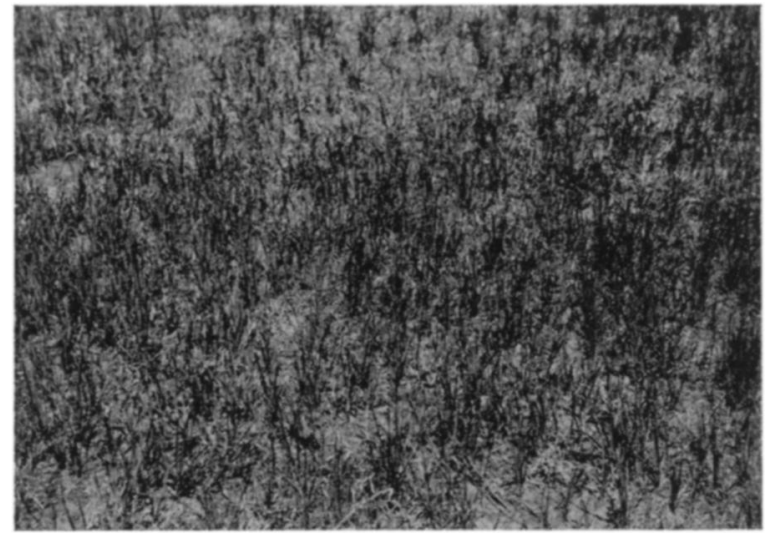

Frg. 22. Mixed prairie resulting from the mid-grass, Agropyron smithii, invading territory occupied by the short grass, Buchloe dactyloides. Carleton, Neb., May 10,1940 .

\section{Other Climax Grasses}

Abundance of June grass (Koeleria cristata) is more difficult to evaluate than that of most other species. This is because of its greater instability and shorter life span. It was greatly harmed by the drought. The root system is shallow (15 to 28 inches) and its decided predrought occurrence on dry uplands resulted in great losses. But quantities of seed on the soil aided in quick reestablishment of this species of boreal origin during the following spring and early summer. In fact, certain prairies which lost heavily were quickly repopulated by nearly pure stands of June grass only to be bared once more when extreme drought struck again. Thus, while June grass has increased generally at several periods, its gains seem temporary. Large, persistent bunches are rarely found. It is a drought evader profiting by early growth, summer dormancy, and autumnal development, as well as by decreased competition. It is found mostly where vegetation is very open, and little occurs in stands of western wheat grass or bluestem prairie. There was much less June grass at the end of the drought than at its outset.

Pennsylvania sedge (Carex pennsylvanica) has, of course, the grass life form and may be considered here. It was a minor component of the vegetation, but locally, as on dry ridges, it sometimes formed 5 to $\mathbf{1 0}$ percent of large areas and in very limited ones as much as one third or more of the plant cover. It is drought-resistant and has gradually increased. Sometimes it forms nearly pure stands in patehes many square yards in extent, more often its increase has been general and it is now scattered as before throughout the prairie but in very much greater abundance.

Plains muhly (Muhlenbergia cuspidata) was formerly so rare that it was not mentioned in the monograph on prairie among the 50 minor grasses. This drought-resistant, western species has gradually migrated eastward and increased in prairie and pasture until it is no longer uncommon. In fact, it forms small pure stands on many dry hills and xeric slopes (Fig. 23).

Sand dropseed (Sporobolus cryptandrus), following the early years of drought and consequent widespread losses of pasture grasses, has increased rapidly in pastures from the status of an occasional invader to a species of major importance. Over thousands of ranges it has spread so widely as to become a dominant or the dominant species. It has repopulated vast areas left nearly bare by the death of bluegrass, little bluestem, and other pasture plants. This western species has given stability and good productivity to pasture lands too dry for more mesic grasses. These facts are essential to an understanding of its invasion of the bared areas in prairie. This took place only slowly and only during the latter years of drought. In true prairie this bunch grass plays the part of a preclimax dominant. It has entered the prairie only in the bared places and only in relatively small amounts.

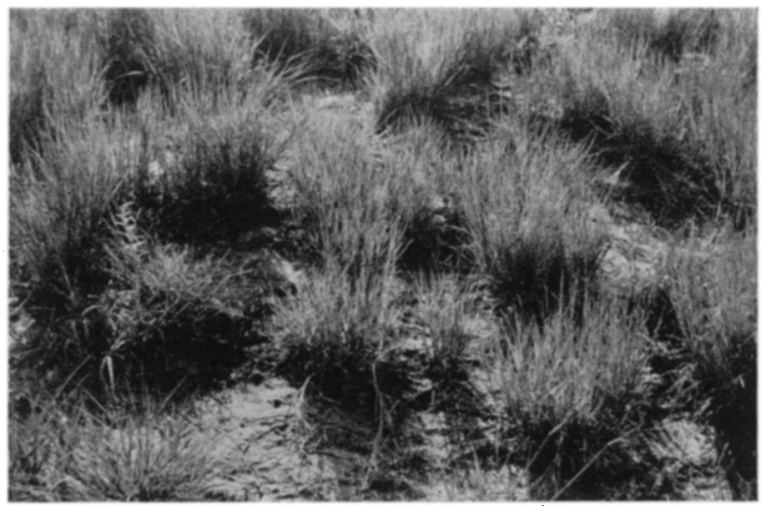

Fig. 23. Pure stand of Muhlenbergia cuspidata on the crest of a ridge at Nelson, Neb., June 16, 1939.

Tall panic grass (Panicum virgatum), nodding wild rye (Elymus canadensis), and slough grass (Spartina pectinata) have retained their former abundance on lowlands with a rather constant supply of ground water or water from runoff. Such places, however, are relatively few. In general, there has been a great shrinking of the territory in ravines and lowlands occupied by these species. Frequently they have been replaced by big bluestem, as soil aeration was improved, or by western wheat grass. Clearly, all three of these meso-hydrophytes have greatly decreased. 
Axnual Grasses

Immediately following the drought, the bared soil, exposed to erosion by wind and water, was populated thinly to thickly by annual grasses and other weedy species. Chief among the grasses were six-weeks fescue (Festuca octoflora), chess (Bromus secalinus or closely related species), and little barley (Hordeum pusillum). These sometimes covered whole hillsides in dense stands (Weaver and Albertson 1936). Bromus tectorum and Panicum capillare were other abundant ruderals of wide distribution. In general, the bared or sem:bared areas were largely reclaimed by long-lived grasses or by certain native forbs. Thus, later in the drought years these annual grasses, where present, chiefly occupied the smaller interspaces and, with rare exceptions, were not found in large belts or patches as formerly.

\section{Studies on the Composition of Plant Cover}

An extensive quantitative survey of the total basal cover in the little bluestem type of vegetation was made near the end of the drought. This consisted of a total of 100 quadrats rather uniformly distributed among 10 different prairie areas widely scattered in eastern Nebraska. The basal or ground cover is the actual area occupied by the stems, mats, or tufts of plants about an inch above the soil surface. It was determined by estimating the area occupied in each square decimeter of each quadrat separately. The average of the 100 estimates gave the percentage of basal cover of the entire square meter. The quadrats were taken at random in the same general locations where similar studies had been made in 1929-1931. They included level land, hillerests, and all slopes which were earlier dominated by little bluestem.

The average basal area before the drought was 13.6 percent. The second survey, in 1938, showed that it was only 5.1 percent or about 38 percent of the former amount. There were, of course, considerable variations from the mean; in fact these variations were somewhat greater than those found in the predrought survey (Weaver and Fitzpatrick 1934).

This survey also included the percentage of basal cover composed by various grasses or by forbs in these same quadrats. Methods were the same as those employed before the drought, strips of 20 square decimeters being the unit portion of the quadrat used for each estimation, that is, 5 separate estimates were made in each square meter. This was invariably done by two investigators accustomed to the use of this method (Table 1).

Comparison of the results from the general trueprairie predrought area (column one) with those of the predrought eastern Nebraska prairies (column two) shows, with exceptions, remarkably small differences. But a similar comparison of the quadrats in eastern Nebraska before and after the drought (columns 2 and 3 ) reveals marked changes. Chief among these is the great decrease in Andropogon
TABLE 1. Percentage of basal cover in the Andropogon scoparius type composed of various grasses and forbs. Arrangement of species is in the order of their predrought importance. First column, 130 quadrats in the general area west of the isohyet of 32 inches, where data were obtained in 1929-1931, previous to the drought; third column, 100 quadrats in eastern Nebraska in 1938; second column, 50 quadrats from the same eastern Nebraska prairies as those sampled in column three but taken before the drought.

\begin{tabular}{|c|c|c|c|}
\hline SPECIES & $\begin{array}{r}\text { Percent } \\
\text { Cover }\end{array}$ & $\begin{array}{c}\text { Percent } \\
\text { Cover }\end{array}$ & $\begin{array}{l}\text { Percent } \\
\text { Cover }\end{array}$ \\
\hline Andropogon scoparius & 56.2 & 55.0 & 5.1 \\
\hline Andropogon furcatus & 23.1 & 19.4 & 17.9 \\
\hline Poa pratensis ....... & 5.8 & 4.9 & 5.8 \\
\hline Stipa spartea ....... & 3.1 & 1.6 & 9.7 \\
\hline Sporobolus heterolepis & 2.8 & 7.1 & 11.6 \\
\hline Sorghastrum nutans ....... & 1.4 & 1.8 & 1.7 \\
\hline Bouteloua curtipendula .... & .7 & .6 & 14.3 \\
\hline Koeleria cristata $\ldots \ldots \ldots \ldots$ & .6 & 1.3 & 4.7 \\
\hline \multicolumn{4}{|l|}{ Panicum scribnerianum and } \\
\hline P. wilcoxianum ......... & .3 & .3 & .3 \\
\hline Panicum virgatum ......... & .1 & .0 & .8 \\
\hline Forbs $\ldots \ldots \ldots \ldots \ldots \ldots$ & 4.2 & 4.6 & 11.3 \\
\hline Sporobolus asper ......... & & 1.0 & 2.6 \\
\hline Bouteloua gracilis .......... & & .5 & 3.1 \\
\hline Carex pennsylvanica..... & & .4 & 4.9 \\
\hline Agropyron smithii .... & & & 1.9 \\
\hline Total ... ... & 09 & $\overline{98.5}$ & $\overline{95.7}$ \\
\hline
\end{tabular}

scoparius (91 percent), 2 and the great increases in Stipa spartea (506 percent), Sporobolus heterolepis (63 percent), and Bouteloua curtipendula (2,283 percent). Increases of Bouteloua gracilis, Carex pennsylvanica, Sporobolus asper, and forbs were 520, 1,125, 160, and 146 percent, respectively. Andropogon furcatus decreased slightly but Poa pratensis increased somewhat. No quadrats were located where the invasion of Agropyron smithii was much in evidence. The remaining portion of the total cover (4.3 percent) consisted of weedy annual grasses.

Seedling grasses and forbs were recorded as observed in June and July, 1938, in the 100 meter quadrats. A total of 1,008 seedling grasses was found. Among these the four species with the most seedlings were Panicum wilcoxianum (316), Bouteloua curtipendula (191), Panicum scribnerianum (169), and Sporobolus heterolepis (92). Twentythree species of native forbs and 9 of weeds were represented by a total of 2,930 and 48 seedlings, respectively. Forbs with the most seedlings were Erigeron ramosus $(2,098)$, Senecio plattensis (313), and Aster multiflorus (231). The very low rate of 1 grass seedling per 10 square decimeters was quite usual during the period of drought; frequently there was none (Weaver and Mueller 1942).

The quadrats in Table 1 do not represent the whole range of prairie stations, and are indicative of conditions in eastern Nebraska only. Repeated examination of the relative abundance of the various components of the prairie from the eastern border of drought-damaged true prairie to its replacement westward by mixed prairie gave a broader and dif-

2 It should be made clear that this percentage is not the actual reduction in the amount of grass, which was much the total post-drought vegetation than it did of the total predrought sover. 
ferent picture. This survey was made in 1940, at the close of the drought. According to their abundance and control over the habitat the grasses may be readily divided into four groups. Species in each group are arranged so far as possible in sequence of decreasing abundance.
1. Species of
Major Abundance
Agropyron smithii
Bouteloua curtipendula
Andropogon furcatus
Stipa spartea
3. Species of Intermediate Abundance
Andropogon scoparius
Koeleria cristata
Sporobolus asper
Buchloe dactyloides
Poa pratensis

\section{Species of \\ Considerable Abundance \\ Bouteloua gracilis \\ Sporobolus heterolepis}
4. Species of
Minor Abundance
Muhlenbergia cuspidata
Panicum scribnerianum
Sorghastrum nutans

\section{CONDITION OF GRASSES IN MIXED PRAIRIE}

Three general types of vegetation, with varying degrees of intermixtures, have been described for western Kansas as they appeared before the drought (Albertson 1937). The little bluestem consociation occupied hillsides, where rock outcrops were common, as well as shallow ravines. It also extended over the brows of the hills and far beyond where the slopes continued, but gave way more or less abruptly to short grasses on level uplands.

Little bluestem alone constituted nearly half of the vegetation. In drier places it formed distinct bunches, but a nearly continuous sod-mat in wetter ones. Numerous tall grasses, as Panicum virgatum and Sorghastrum nutans and the mid-grass, Bouteloua curtipendula, were common, the roots usually penetrating deeply into the rock crevices.

The postclimax big bluestem consocies covered lower slopes, the lowland, and deep ravines where water from rainfall was supplemented by the melting of wind-drifted snow and especially by runoff water from the higher land. Big bluestem alone usually composed 75 percent of the vegetation. Its chief associates were Bouteloua curtipendula, Agropyron smithii, and Sporobolus asper var. hookeri, but tall grasses also were common, especially in wetter sites. All were rooted 5 to 7 feet deep in the rich alluvial soil.

The short-grass faciation was found widely distributed over the nearly level uplands where the soil, watered by precipitation only, had developed a mature profile. Westward from Phillipsburg and Hays vast areas of range lands were characterized by the dominance of Bouteloua gracilis and Buchloe dactyloides. These grasses usually composed 80 to 90 percent of the vegetation. They occurred in almost equal amounts in the closed-mat type near Hays where the basal cover varied from 70 to 90 percent, a condition not uncommon over hundreds of square miles of the Great Plains disclimax. In the open-mat type

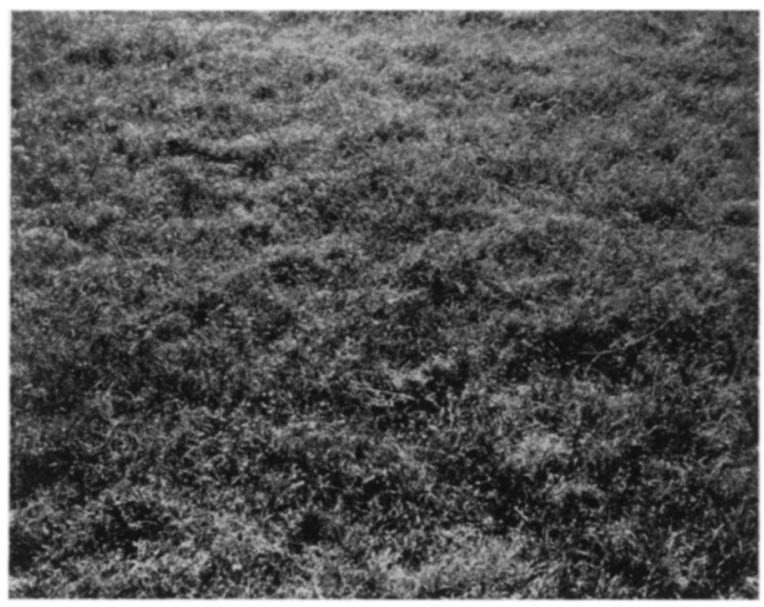

Fig. 24. A typical stand of mixed short grasses of the closed-mat type, which formed excellent cover previous to the dry years.

of depressions with decreased water infiltration and of thin soil, the basal cover was more commonly only 10 to 33 percent. Under such conditions blue grama frequently predominated (ef. Shantz 1911). Where the short-grass sod was best developed there were practically no plants which rose above the 3- to 5inch level of the foliage. But certain low-growing annuals were normal components of the vegetation, as Hordeum pusillum, Festuca octoflora, Plantago purshii, and P. spinulosa.

Although all three types of vegetation recur repeatedly where topography is sufficiently rolling to present the proper conditions of habitat, the shortgrass type is by far the greatest in extent.

Drought and dust have wrought great changes not only in the composition but also in the amount of vegetation (Figs. 24 and 25). They have also caused

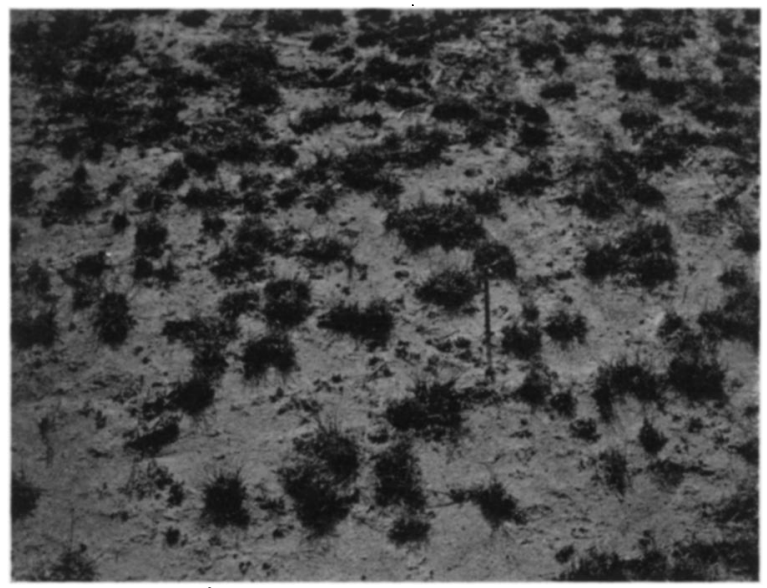

Fig. 25. Vegetation, previously similar to that shown in Figure 24, near the end of the great drought. Note wide spacing of relic tufts, bared soil without mulch, and elevation of the plants somewhat above the general surface, the top inch of soil having been blown or washed away. 
great changes of vegetational boundaries between grassland types. Movements of grass populations have been from the more xeric toward the less xeric habitats. In many places the only plants that survived were those in moister places such as buffalo wallows, ditches, and ravines. Reduction of cover to 2 to 10 percent was not uncommon. Frequently large areas of nearly level grassland were covered with several inches of dust, brought by the wind from adjacent cultivated fields. Under extreme conditions the wind-blown soil formed long, tortuous drifts under which the native vegetation was buried and completely destroyed.

\section{ANDROPOGON SCOPARIUS}

Before the drought, little bluestem ranged far out from its hillside habitat into the short grasses on the tablelands. Here it occurred widely scattered as isolated bunches or in small patches. It was here that the first effects of the drought became apparent and only dead crowns of this species remained after 1934 . Even in its own type, this species was materially reduced, being replaced chiefly by side-oats grama and blue grama. At the end of the drought period only occasional bunches of little bluestem could be found even on north-facing slopes or in depressions on the hillsides where runoff water accumulated. Thus, this dominant was reduced from about 45 percent of the total vegetation to only 1 percent. It also practically disappeared from the "hard lands" westward and was found only rarely.

\section{Andropogon Furcatus}

Big bluestem not only dominated the bottoms of ravines and lowlands but was also scattered throughout the little bluestem type on the hillsides. The effect of the drought upon this species became evident somewhat later than upon most other grasses associated with it. On the hillsides where little bluestem was dominant, big bluestem, due to a somewhat deeper root system, was able to survive with little loss several years after little bluestem died. But during the later years of drought it was reduced in area occupied to only one fourth of its predrought abundance. On the lower slopes and in ravines where big bluestem was dominant, the total cover of grass was not significantly decreased but merely changed in composition. It was here that large areas of nearly pure big bluestem, so common before the drought, were almost entirely replaced by other species such as western wheat grass, dropseed (Sporobolus asper var. hookeri), side-oats grama (Bouteloua curtipendula), and even by buffalo grass and blue grama grass. Thus, at the end of the drought its abundance was often only about one fifth of the normal.

\section{Bouteloua Curtipendula}

Side-oats grama had a wide predrought distribution in the mixed prairie. It was a chief associate of big bluestem in the postelimax type of grassland, where it was a dominant.species. Its bunches were also scattered widely throughout the little bluestem type on the hillsides, and it was one of the four im-

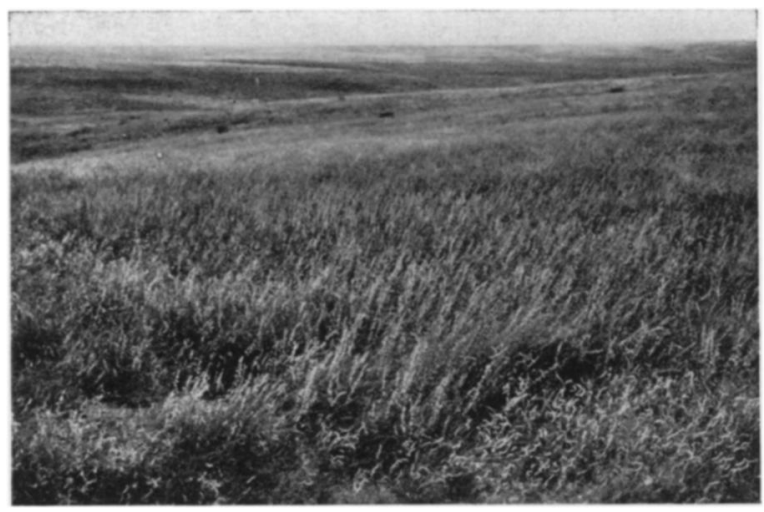

FIG. 26. Dense stand of side-oats grama which has largely replaced little bluestem on the hillsides. Hays, Kan., Sept. 8, 1939.

portant mid-grasses that extended into the short-grass type more or less throughout western Kansas, eastern Colorado, and adjacent areas. But by the end of the drought even this xeric species was enormously reduced in numbers and over a wide territory it entirely disappeared from among the short grasses. Conversely, it made steady gains in the little bluestem type and was the chief invader of the soil left bare by the death of little bluestem (Fig. 26). An increase in amount of two- or threefold was usual. Likewise, in the ravines and on lower slopes it frequently replaced big bluestem.

\section{Aristida Purpurea and A. Longiseta}

The wire grasses were most abundant and most permanently entrenched along hillsides in the little bluestem type. They also extended widely and often abundantly over the short-grass disclimax. The pattern was variable according to type of soil and degree of disturbance. On the heavier silt-loams or very fine sandy loams these low bunch grasses were few, but they increased with coarser sand content of soil, and were often of great abundance in subseres (Fig. 27). Upon the advent of the drought, these shallowly

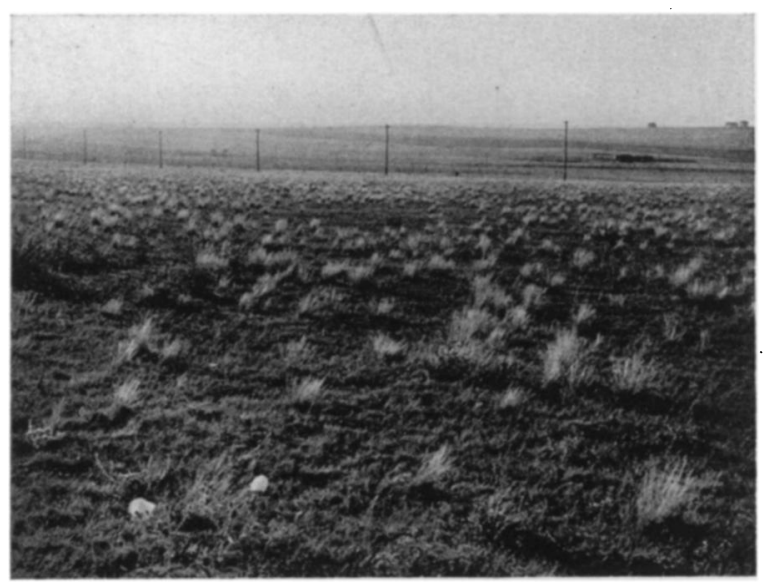

Fig. 27. Bunches of wire grass (Aristida purpurea) in short-grass sod near Colorado Springs, Colo., preceding the dry cycle of 1933-41. 
rooted grasses were among the first to show the effects of decreased water content. By 1935 only their dead crowns could be found in the short-grass type. Even on the hillsides they suffered a high rate of mortality and persisted only in places that were protected by some form of vegetation or as a result of irregular topography.

\section{Bouteloua Gracilis}

Blue grama with its codominant, buffalo grass, constituted fully four fifths of the entire vegetation in the short-grass type. This predrought turf, with small openings scattered throughout, has received so much abuse from edaphic and atmospheric drought, dust, overgrazing by domesticated animals, jack rabbits, and grasshoppers, that it is now composed of nearly isolated remnants of sod in a wilderness of bared soil. Yet the present vegetation, sorely depleted as it is, consists almost entirely of these same two short grasses. Thus, during the stress of drought most of the blue grama was killed, but that which remained grew in small tufts or bunches a few inches to many feet apart (Fig. 25). In places where runoff was great, large tracts of many square rods were completely denuded of this grass and all other vegetation. Other vast areas were bared or almost denuded by a covering of dust. In contrast to these losses which ranged from 50 to 100 percent, gains were made by blue grama spreading on hillsides and into upper ravines where certain mid-grasses had succumbed. In fact, most lowlands were also occupied by this grass.

\section{Buchloe Dactyloides}

Buffalo grass often shared the soil more or less equally with blue grama before the great drought. In many places this stoloniferous grass entirely disappeared from the mixture during the early years of desiccation, and in practically no location was it damaged only lightly. During the short periods with moist soil, the stolons developed rapidly where this grass remained, often an inch per day, but usually the new growth was killed by succeeding dry periods. The gains and losses of buffalo grass during this period of adversity fluctuated to a much greater extent than did those of blue grama. The soil in the shortgrass type, bared as a consequence of drought, was usually repopulated with weedy species such as little barley (Hordeum pusillum), peppergrass (Lepidium densiflorum), sticktight (Lappula heterosperma), Russian thistle (Salsola pestifer), lamb's quarters (Chenopodium album), and many others. These weeds were often detrimental to the recovery of buffalo grass because of their shade and also because of their rapid absorption of water (Fig. 28). By the end of the drought, despite rapid and repeated local recovery, buffalo grass had lost much more than the more stable blue grama. Of the present (1940) cover of short grasses throughout this arid western region, buffalo grass constitutes probably not more than one half as much as does blue grama.

Variations in the cover of short grass with the drier and less dry years have been fully presented by Albertson and Weaver (1942), and also in connection with an extensive survey of hundreds of square miles of western range (Weaver and Albertson 1939). The most reduced cover in the shortgrass type occurred in 1936 (5 and 2.5 percent in moderately grazed and overgrazed ranges, respectively) and in 1939 in protected ranges, where it was reduced to 22 percent. There was some increase, due largely to the spread of buffalo grass, until 1940 when there was again a sharp decrease. This was followed by rapid gains in 1941 when the good rains came.

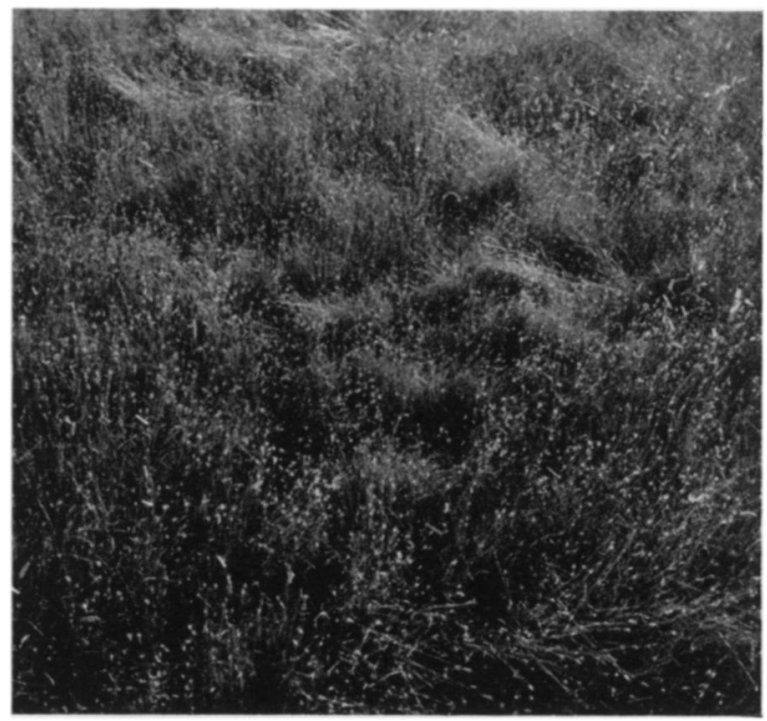

Fig. 28. Detail of dense growth of little barley (Hordeum pusillum) at Phillipsburg, Kan., on July 18, 1941. The grass, which has seeded, overtops scattered mats of buffalo grass and blue grama.

\section{Panicum Virgatum}

Tall panic grass was most commonly found growing in the big bluestem habitat in clumps from one to several feet in diameter. It occurred less frequently in smaller bunches among other grasses in the little bluestem type on the hillsides. This deeply rooted grass suffered comparatively small losses. During the less severe years of drought the flower heads were borne close to the ground but during the driest ones none developed.

\section{Agropyron SMIthit}

Western wheat grass was widely distributed throughout the mixed prairie in 1932. It occurred in greatest abundance in the deepest soil on the ecotone between the short-grass and little bluestem types. It also comprised a considerable portion of the vegetation on the lower slopes. By 1940, it had frequently taken complete possession of large areas on the hillsides where the soil was deep enough for it to gain a foothold. Even on the lowlands where big bluestem was usually dominant, it formed an important part of the vegetation (Fig. 29). It is also 


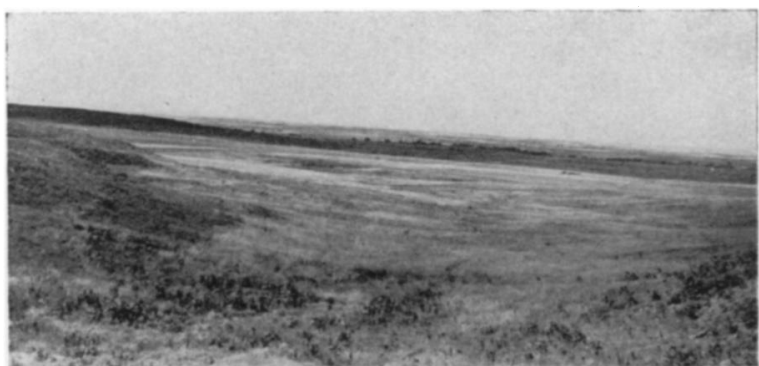

Fig. 29. Increase of western wheat grass (light color) over lower slopes and in ravines at Hays, Kan., as it appeared in the spring of 1939.

found in buffalo wallows scattered throughout the short-grass habitat, but here the living rhizomes remained dormant during several years with little or no growth above ground.

\section{Other Perennial Grassés}

Sand dropseed (Sporobolus cryptandrus) is perhaps the most widely spread and important of the minor grasses. Under normal conditions of precipitation it was usually restricted to sandy soil, but with the destruction of climax vegetation by drought and the appearance of bare areas, this species spread rapidly on hard lands. It is not uncommonly a local dominant (Fig. 30).

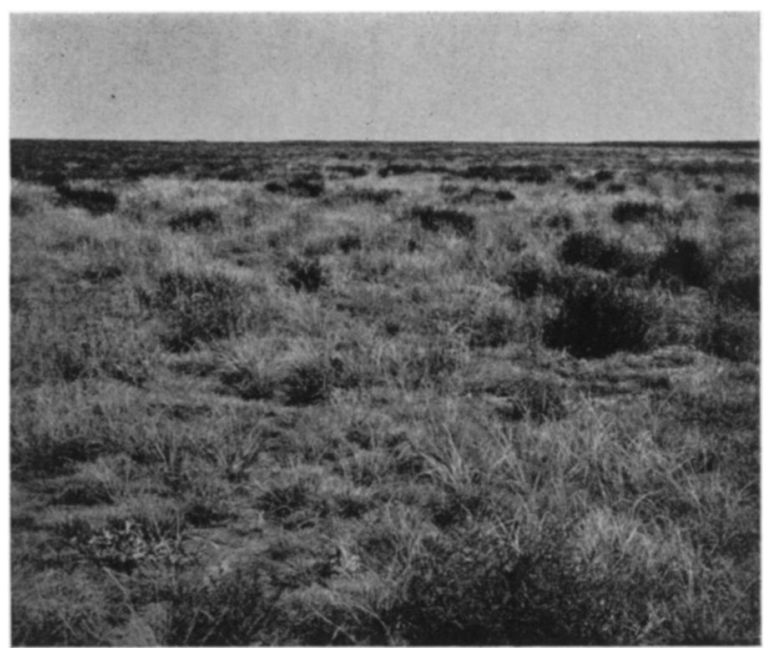

Fig. 30. Russian thistles (dark elumps) and sand dropseed (light) in a range near Marienthal, Kan., at the close of the drought.

Squirreltail (Sitanion hystrix) was widely distributed but found most abundantly where the cover of short grasses was more or less interrupted as along transitional areas into mid-grass types. Its root system is shallow and it perished in the early years of drought. By 1940 it was rarely seen.

June grass (Koeleria cristata) occupied a position very similar to that of squirreltail and suffered the same fate. In fact, none could be found at the close of the drought period. Carex praegracilis, fre- quently found in small openings in the short-grass cover, has likewise disappeared.

The occurence of hairy grama (Bouteloua hirsuta) and hairy dropseed (Sporobolus pilosus) is rather definitely limited, in western Kansas, to abrupt slopes in the little bluestem type where rocks outcropped. Both species maintained their abundance or gained slightly and are now the most important grasses in their restricted habitats.

Indian grass (Sorghastrum nutans) and wild rye grasses (Elymus canadensis and E. virginicus) were usually limited to local areas in the big bluestem habitat. Occasionally, however, small clumps were found ranging well up the hillsides. In these more xeric locations they succumbed and they have not increased even on the lowlands.

Dropseed (Sporobolus asper var. hookeri) was limited to small, local patches on the lower hillsides and upper ravines previous to the drought. With decrease in big bluestem, however, it made rapid gains and now has full possession of many rather large areas on lowlands. Plains muhly (Muhlenbergia cuspidata) is of little importance. It is usually limited to sandy knolls or rocky outcrops.

Tumblegrass (Schedonnardus paniculatus) and windmill grass (Chloris verticillata) were commonly found in disturbed places where they sometimes formed the major part of the cover. Both, however, were unable to survive the drought and were early replaced by sand dropseed. They are now found only occasionally in the short-grass type where the cover has been materially reduced by drought and accumulations of dust.

\section{Annual Grasses}

Before the dry years the only annual grasses of much importance in the mixed prairie and shortgrass diselimax were little barley (Hordeum pusillum) and six-weeks fescue (Festuca octoflora). Even little barley was not abundant. As the soil became bared of vegetation, however, it increased greatly and often produced a crop of forage of one to two tons per acre (Fig. 28). Six-weeks fescue, on the other hand, suffered a high rate of mortality and at the close of the drought was seen infrequently.

Other weedy annual grasses that invaded open places were downy brome (Bromus tectorum), chess (B. secalinus), B. japonicus, witch grass (Panicum capillare), and ill-scented love grass (Eragrostis cilianensis). Under most adverse conditions, where the native cover was almost entirely destroyed, these grasses produced a new but often patchy cover annually (Fig. 31).

\section{Studies on the Composition of Plant Cover}

The amount and composition of basal cover were ascertained at the end of the drought. Data are from more than 100 permanent meter quadrats at Hays, Kansas, and territory extending 200 miles southwestward. They were located not only in the short-grass type but also in both big bluestem and little bluestem habitats and in the transition between the latter and the short grasses (Table 2). 


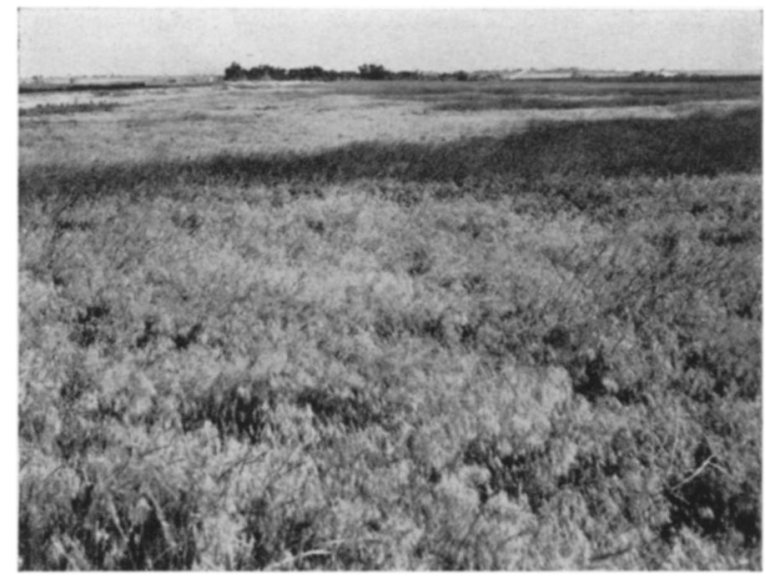

FIG. 31. Downy bromegrass (light) alternating with patches of western wheat grass (dark) on June 25, 1941. Scattered, relic native grasses are completely hidden by the bromegrass.

TABLE 2. Percentage composition of the basal cover of various species of four chief communities of mixed prairie vegetation before and after the great drought.

\begin{tabular}{|c|c|c|c|c|c|c|c|c|}
\hline \multirow{2}{*}{ Species } & \multicolumn{2}{|c|}{$\begin{array}{l}\text { Short- } \\
\text { grass } \\
\text { type }\end{array}$} & \multicolumn{2}{|c|}{ Ecotone } & \multicolumn{2}{|c|}{$\begin{array}{c}\text { Little } \\
\text { bluestem } \\
\text { type }\end{array}$} & \multicolumn{2}{|c|}{$\underset{\substack{\text { Big } \\
\text { blupe }}}{\text { typem }}$} \\
\hline & 1932 & 1940 & 1932 & 1940 & 1932 & 1940 & 1932 & 1940 \\
\hline Bouteloua gracilis. . & 48.5 & 59.0 & 43.0 & 66.0 & 8.0 & 31.0 & 3.0 & 12.0 \\
\hline Buchloe dactyloides........ & 47.5 & 35.0 & 42.0 & 30.0 & 0.5 & 6.0 & 2.0 & 20.0 \\
\hline \multirow{2}{*}{\multicolumn{9}{|c|}{ Aristida purpurea and $A}}$. \\
\hline & 1.5 & 0.0 & 1.0 & 0.0 & 2.0 & 1.0 & & . \\
\hline Sporobolus cryptandrus..... & 0.0 & 3.5 & & $\cdots$ & 7.0 & 7.0 & & \\
\hline Sitanion hystrix . . . . . . . & 0.5 & 0.0 & 1.0 & 0.5 & & & & \\
\hline Schedonnardus paniculatus.. & 0.0 & 1.0 & & & & & & \\
\hline Andropogon scoparius...... & 1.0 & 0.0 & 5.0 & 0.0 & 45.0 & 1.0 & 1.0 & 0.0 \\
\hline Bouteloua curtipendula. . & $\cdots$ & .... & 5.0 & 1.0 & 17.0 & 42.0 & 5.0 & 15.0 \\
\hline Andropogon furcatus.... & $\cdots$ & & 1.5 & 0.0 & 17.0 & 4.0 & 76.0 & 15.0 \\
\hline Sporobolus pilosus..... & $\cdots$ & & 0.1 & 1.0 & 1.0 & 2.0 & & \\
\hline Bouteloua hirsuta . ........ & ․ & . & $\ldots$ & $\ldots$ & 2.0 & 5.0 & & $\cdots$ \\
\hline \multicolumn{9}{|l|}{ Panicum virgatum........... } \\
\hline \multicolumn{9}{|l|}{ Agropyron smithii. ....... } \\
\hline \multicolumn{9}{|l|}{ Sorghastrum nutans....... } \\
\hline \multirow{3}{*}{\multicolumn{9}{|c|}{$\begin{array}{l}\text { Elymus virginicus.......... } \\
\text { Sporobolus asper var. } \\
\quad \text { hookeri } \ldots \ldots \ldots \ldots \ldots\end{array}$}} \\
\hline & & & & & & & & \\
\hline & & & & & & & & \\
\hline Total & 99.0 & 98.5 & 98.6 & 98.5 & 99.5 & 99.0 & 99.0 & 98.0 \\
\hline
\end{tabular}

In the short-grass type, Bouteloua gracilis constituted 48.5 percent of the total vegetation (that is, the 90 percent of short-grass cover) in 1932. In 1940, it composed 59 percent of the greatly reduced plant cover (that is, about 20 per cent of the predrought amount). The cause for the increase in relative abundance-not total amount-of Bouteloua gracilis was a decrease in the abundance of Buchloe dactyloides. Conversely, buffalo grass composed 47.5 percent of the original cover but only 35 percent of the greatly reduced one at the end of the drought. The species of Aristida, Sitanion hystrix, and Andropogon scoparius had disappeared completely. Sporobolus cryptandrus and Schedonnardus paniculatus, although never important in this type, were found only at the close of the drought.
When the drought ended, about 1940, the highly drought-resistant blue grama composed approximately two thirds of the vegetation in the short-grass type. Buffalo grass alone constituted approximately one third; other grasses and forbs were very sparsely represented. But this relationship changed quickly owing to the rapid vegetative spread of buffalo grass. This is well illustrated by another group of 25 shortgrass quadrats at Hays, Kansas. In 1939, the basal cover provided by grama grass and buffalo grass was 11.6 and 10.5 percent, respectively. The next year the percentages were 10.8 and 8.1. But in 1941 buffalo grass had gained greatly, the percentages of cover in the same sequence being 15.7 and 36 .

In the ecotone, the behavior of Bouteloua gracilis and Buchloe dactyloides was similar to that in the short-grass type. Blue grama increased in percentage from 43 to 66 ; a decrease from 42 to 30 was ascertained for buffalo grass. Five mid- and tall grasses, found in amounts of 5 percent or less, suffered losses (Table 2).

In the Andropogon scoparius type, the dominant decreased from 45 to 1 percent. Species of Aristida and Andropogon furcatus suffered losses, the bluestem decreasing from 17 to 4 percent. The more xeric species increased. Bouteloua gracilis increased from 8 percent to $31, B$. curtipendula from 17 to 42 percent, but Buchloe dactyloides from only 0.5 percent to 6 (Table 2 ).

In the Andropogon furcatus type, the dominant decreased from 76 percent to 15 , and $A$. scoparius from 1 percent to 0 . Sorghastrum nutans and Elymus virginicus occurred in small amounts but both decreased; the 2 percent of Panicum virgatum remained unchanged. All other species increased, Bouteloua curtipendula threefold, Agropyron smithii from 4 to 20 percent, and Sporobolus asper var. hookeri from 2 to 13 percent. Even the short grasses now received enough light to spread among the greatly thinned and dwarfed taller species. Bouteloua gracilis increased from 3 to 12 percent but Buchloe dactyloides from 2 to 20 .

Considering the whole portion of the mixed prairie and its short-grass disclimax that were studied, the grasses may be divided into three groups. Species in each group are arranged as nearly as possible in order of decreasing importance. This 1940 distribution of grasses, including certain weedy species of the subsere, is as follows:

$$
\text { Short-grass Type }
$$

Species of Major Abundance

Bouteloua gracilis Buchloe dactyloides

Species of Intermediate Abundance

Bouteloua curtipendula Agropyron smithii Sporobolus cryptandrus

\section{Species of Minor Abundance}

Aristida spp. Chloris verticillata

Schedonnardus paniculatus ion hystrix Muhlenbergia cuspidata 
Other Types

Species of Major Abundance

Bouteloua curtipendula Andropogon furcatus Agropyron smithii Sporobolus asper var. Bouteloua gracilis Buchloe dactyloides hookeri

Species of Intermediate Abundance Panicum virgatum Bouteloua hirsuta Sporobolus cryptandrus Sporobolus pilosus

Species of Minor Abundance Andropogon scoparius Sitanion hystrix Aristida spp. Sorghastrum nutans Elymus canadensis Elymus virginicus

\section{RESURVEY OF FORBS}

Forbs constitute an important part of prairie vegetation. They furnish the seasonal aspects and contribute largely to the layering in grassland both above and below ground. Nearly all of the legumes are valuable as forage and they contribute considerable amounts to the total yield. The lead plant (Amorpha canescens) alone supplied 200 pounds per acre of air-dry forage from a prairie in western Iowa when the vegetation was clipped near the soil surface four times during the growing season (Fig. 32). The list of native forbs that are regularly eaten by stock and hence decrease under close grazing is a long one; the list of those that are grazed but little and increase in pasture is much shorter (Weaver and Hansen 1941). Undoubtedly forbs provide a valuable variety in the diet of livestock. Native forbs, in conjunction with various kinds of grasses, have long been employed as indicators of the degree of severity

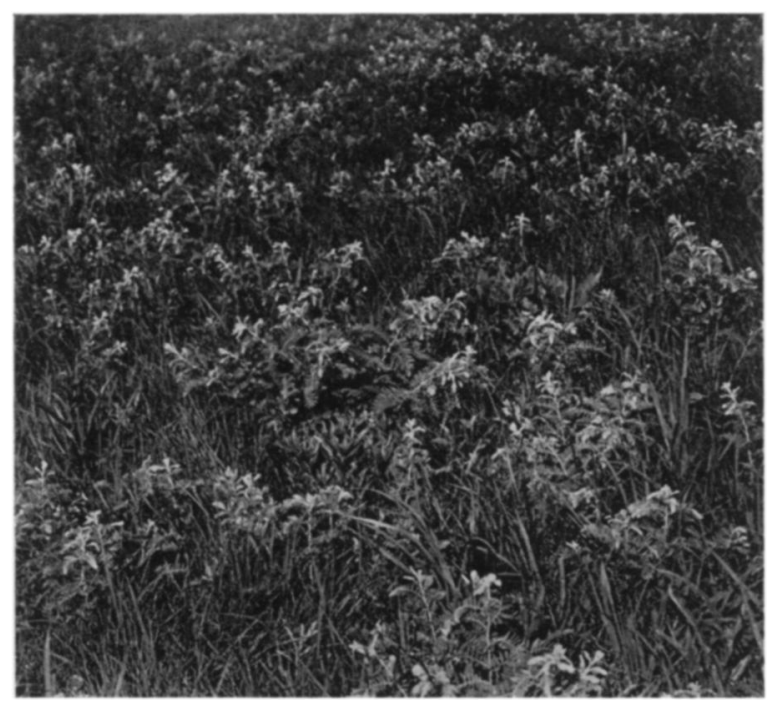

Fig. 32. A thick stand of prairie shoestring or lead plant in ungrazed prairie near Guthrie Center, Ia., on June 14, 1937. of grazing. When supplemented by a knowledge of the presence of invading species and conditions of the surface soil, they afford a reliable index of the degree of degeneration from prairie and of the productivity of range land. On these bases, midwestern native pastures have been classified into four distinct stages of deterioration.

Forbs have long been used as indicators of mesophytism in types of grassland, since most of them thrive on the water supply that is available in excess of the needs of the grasses. More than half of the upland, true-prairie forbs are rooted at greater depths than 5 to 6 feet and thus beyond the depths of usual root penetration of upland grasses. In mixed prairie, although still abundant, they were always fewer. Here, too, soil moisture is less plentiful and deep soils constantly dry. Small wonder that, with the oncoming of several years of greatly reduced precipitation and severe atmospheric drought, the toll of forbs was great and losses especially pronounced in the mixed prairie and short-grass plains disclimax.

The losses of forbs have been studied throughout the drought. Since many prairies were visited at regular intervals each year and hundreds of quadrats recharted annually, a comprehensive record of the actual weakening and death of forbs was obtained. These studies show that the decrease in numbers was not gradual but sporadic, corresponding with severity of drought. Deeply rooted plants such as Rosa arkansana, Amorpha canescens, and Kuhnia glutinosa have frequently held out against drought and competition with western wheat grass until the last two or three years. Some still persist. In many prairies they are about the only forbs that remain except drought-evading species which grow only in spring. Quite in contrast, Antennaria campestris, Fragaria virginiana, and many other shallowly rooted plants were nearly all killed at the first great impact of the drought in 1934 and have never reappeared, except a few in the most favorable sites. Others like Helianthus rigidus and Echinacea pallida lingered a second year; plants of most species persisted a little longer and were continuously depleted in numbers with recurring periods of drought.

By 1940 most species of forbs had decreased greatly, some almost to the point of extinction, as a consequence of the continued recurrence of dry years. This pertains to those that root deeply as well as to those of moderate and shallower rooting habits. Loss of legumes was especially noticeable. Little loss occurred in Iowa; it was very heavy in eastern Nebraska and Kansas, and westward very few species were found during the later years of the drought. Only a few reports of their decreases have been published and these have been in connection with deterioration of the grasses (Weaver, Stoddart, and Noll 1935; Weaver and Albertson 1939; Weaver 1942).

\section{Nature and Causes of Losses}

During the first great impact of drought, large numbers of forbs succumbed with the grasses. Others 
suffered midsummer death above ground only. These recovered the next year only to undergo severe drying in 1936. There is some evidence that certain species, persisting on subsoil moisture at depths below 4 to 5 feet, extended their roots even more deeply. But even at the beginning of drought, available soil moisture below the solum, although extending deeply, was small in amount. Throughout the years of drought, precipitation did not augment this supply and even deeply rooted plants were forced to depend upon water largely from current precipitation. Thus, as years of severe drought (1934, 1936, 1937, 1939) alternated with those of more moderate soil moisture deficiencies, loss of forbs was progressive. In 1939 it was stated that "most species of forbs . . . have gradually succumbed to the continued drought, until they are only one-half to onethird of their former abundance" (Weaver and Albertson 1939). Since that time there have been further marked decreases in a weakened plant population.

Drought occurred during various periods of the year-early spring, late spring, midsummer, and late summer. Wilting, drying, and more or less complete defoliation of tops by grasshoppers were common phenomena later in the drought cycle among even the most deeply rooted species. Dwarfness in stature was characteristic of the more drought-resistant species which continued to grow slowly, even if intermittently. Lack of debris on the soil with little or no cover of grasses and lack of the usual shade accentuated the drought. Failure to complete vegetative growth or to blossom or ripen seed was usual. Seasonal aspects, if any, were poorly marked, compared with the former wealth of flowers. This resulted finally in a dearth of viable seed which, in conjunction with a general environment unfavorable to seedling establishment, resulted in few seedlings. Seedlings were not found except rarely in the hundreds of permanent quadrats that have been carefully examined year by year (Weaver and Hansen 1941a; Albertson and Weaver 1942). Thus little or no replacement of the forb population occurred over a period of 6 or 7 years.

Development of only a few stems from crowns of perennial species that normally supported many revealed at once the severe environment and the weakened condition of the vegetation. Often the forbs were robbed of the meager water supply in spring by the growth of a host of annual grasses, some of which were native, as Festuca octoflora, but mostly ruderals such as various species of bromegrass and little barley. Although weedy forbs are still plentiful in mixed prairie, eastward the scourge of peppergrass (Lepidium densiflorum), horseweed (Leptilon canadense), and, more locally, goat's beard (Tragopogon pratensis), so common until 1938, has vanished.

In many prairies, especially westward, death by mechanical injury from blowing dust overtook aboveground parts, or both forbs and grasses were smothered under a blanket of dust a few to many inches thick. Where denudation eastward resulted from extreme drought and only deeply rooted forbs survived, these sometimes died because of invasion of needle grass and more regularly by a similar invasion of western wheat grass.

During the last 3 years many drought-bared areas had been reclaimed by needle grass. The rather small, uniform bunches so completely utilized all available water in their early growth that all relic forbs had been killed and rarely was any plant to be found other than the grass. An exception was the droughtresistant, many-flowered aster (Aster multiflorus). The grass in repopulating the area revealed complete dominance on hillsides where a few years before a wealth of forbs was growing as lower, middle, and upper layers with little bluestem. Side-oats grama and blue grama often occurred in similar, relatively new stands without accompanying forbs. The very detrimental role of the dense sod of wheat grass has been illustrated elsewhere.

A few species of native forbs profited by the death of their competitors. Chief among these were Aster multiflorus, Solidago glaberrima, Erigeron ramosus, and the annuals, Specularia perfoliata, and Silene antirrhina. Increase of the annuals was marked during the first years of drought only and Erigeron has fluctuated greatly from year to year. The two perennials, both propagating by means of rhizomes, although not so abundant at the end of the drought as in 1937, still occur in true prairie in numbers greatly exceeding the predrought normal.

Another group of species, practically all with rootstalks or other storage organs, has increased, some to a remarkably great extent.

\section{Comparative Number of Long-Lived Species}

Complete lists of the species of native forbs found at each of three groups of prairie stations were made during the years 1930-1932 and thus before the drought (Weaver and Fitzpatrick 1934). Oakland and Glenwood, Iowa, were not included, hence data from two other typical southwestern Iowa prairies were used. Similar lists were made in 1938 and again in 1940. These lists, with the annual forbs omitted, provide a basis for comparing the destructive effect of the drought. They tell nothing, however, of the abundance of species, but merely the kinds that occurred, even if represented by a single relic plant (Table 3).

TABLe 3. Number of species of long-lived native forbs found at the several stations in true prairie before, during, and at the end of the drought.

\begin{tabular}{|c|c|c|c|c|c|c|c|}
\hline Stations & & 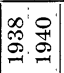 & Stations & 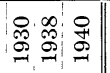 & Stations & 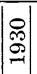 & 文 \\
\hline Corning . . . . . & 82 &. .80 & Lincoln... . & 524441 & Carletön... & $35 \mid$ & 2219 \\
\hline Guthrie Center & 88 &. .87 & Hebron... & 494135 & Clay Center & 35 & 3224 \\
\hline Anita........ & 84 & . . 8 & Belleville. & $483146^{3}$ & Montrose. . & 44 & $23 \mid 21$ \\
\hline Average... & 85 & .882 & & 503941 & & & $26 \mid 21$ \\
\hline
\end{tabular}

3 This prairie was severely damaged early in the drought but maintained one excellent large area of bluestems and ac. companying forbs. 
Although the prairies varied somewhat in size, at least one in each group contained 80 or more acres, and the smallest one (Clay Center) possessed as many species as the others in its group. Average mean annual precipitation decreased from 32.4 inches in Iowa to 25.9 inches at the Carleton group of stations. Accompanying this reduction in precipitation was a decrease of 55 percent in average number of long-lived forbs. The percentage decrease at the Lincoln group of stations with an average precipitation of 27.1 inches was 41 . These are the predrought figures. Losses during drought were progressive, except at Belleville. In 1940, only half as many species occurred at the Lincoln group as in Iowa, and at the stations where forbs were overrun by western wheat grass, only about one fourth of the number occurring in Iowa was found.

\section{Relative Size Before and During Drought}

The same species of forb decreased considerably in stature even before the drought as its habitat became drier westward. The native bluestem grasses also have been shown to be dwarfed in a similar manner. For example, on August 29, 1929, height of little bluestem in a series of prairies in Iowa varied from 16 to 26 inches. It was 10 to 11 inches less in a similar group of grasslands near Lincoln. On July 17 to 19, 1931, big bluestem at a group of western Iowa stations varied from 18 to 40 inches in average height, but a week later in prairies southwest of Lincoln the height was only 15 to 18 inches. Stature of forbs varied somewhat in proportion to the grasses.

During and near the end of the dry years, differences in stature were greatly increased, since drought was either absent or not severe in the Iowa prairies. Hundreds of measurements have been made but only a few will be used to illustrate a general condition.
Kuhnia glutinosa was 30 to 42 inches tall in Iowa, 12 to 14 inches at the Lincoln stations, but only 4 to 10 in the wheat grass group (Fig. 33). Similar data for Rosa arkansana are 24 to 36,14 to 22 , and 5 to 7 inches, respectively. Those for Amorpha canescens are 19, 7, and 5 inches. At the Iowa stations a tall layer of forbs was always consp:cuous above the bluestem grasses (Figs. 34, 35, and 36). Helianthus rigidus, for example, was 40 to 60 inches tall with 4 to 6 flower heads per stalk. The few relies at Lincoln were only 12 to 18 inches high and had a single, small, terminal flower. At some bluestem stations Amorpha canescens was sometimes the sole species visible above the dwarfed and dried bluestems. A stand of western wheat grass even 14 inches tall obscured the presence of all the widely spaced, dwarfed forbs.

\section{DeCrease in Numbers}

The relative abundance and ecological importance of each species of forb were studied and closely estimated. The various species in a prairie were placed in one of each of five classes or ranks, ranging from the chief society formers to plants of infrequent or rare occurrence. The relative ranking was determined only after carefully studying the abundance, size, duration, density, gregariousness, and basal and foliage cover of each species (cf. Weaver and Fitzpatrick, The Prairie). The rankings in decreasing importance are from 1 to 5 . Since these lists were made before the drought, again in 1938, and near the end of the drought, changes resulting from desiccation are clearly revealed. Changes of importance in 34 species are shown for 6 stations in Table 4; the Iowa stations are not included since little change occurred there.

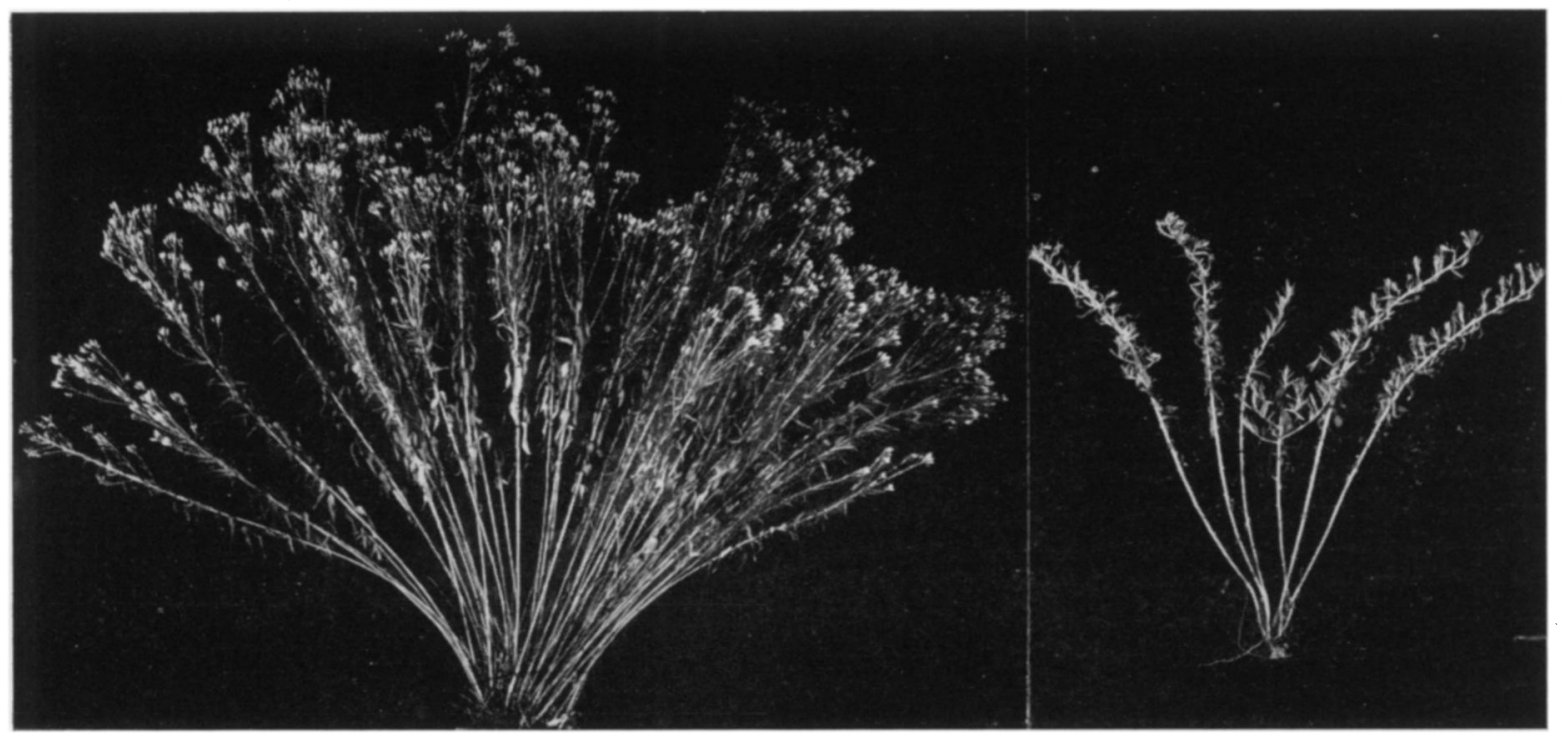

Fig. 33. False prairie boneset (Kuhnia glutinosa) from prairie at Oakland, Ia., and a plant of the same species from Hays, Kan. The first, with 39 stems, is about 42 inches tall; the drought-stricken plant, with stems reduced to $\overline{5}$, is only $1 \tilde{5}$ inches high. 
Examination of table 4 shows that Oxalis violacea alone increased at all stations. Eleven species (designated by a superior 1) remained about the same. Nineteen species (superior 2) decreased considerably or at least at 5 of the 6 stations. Aster multiflorus (including $A$. batesii) decreased at all but two stations. Two others (superior 3) entirely disappeared. Losses were greatest in the wheat grass prairies (last 3 stations with 32 species) where only 5 species (Amorpha, Kuhnia, Liatris punctata, Vernonia, and Cirsium) changed but little, 13 disappeared entirely, and 13 decreased or disappeared at some stations. One, Oxalis violacea, increased.

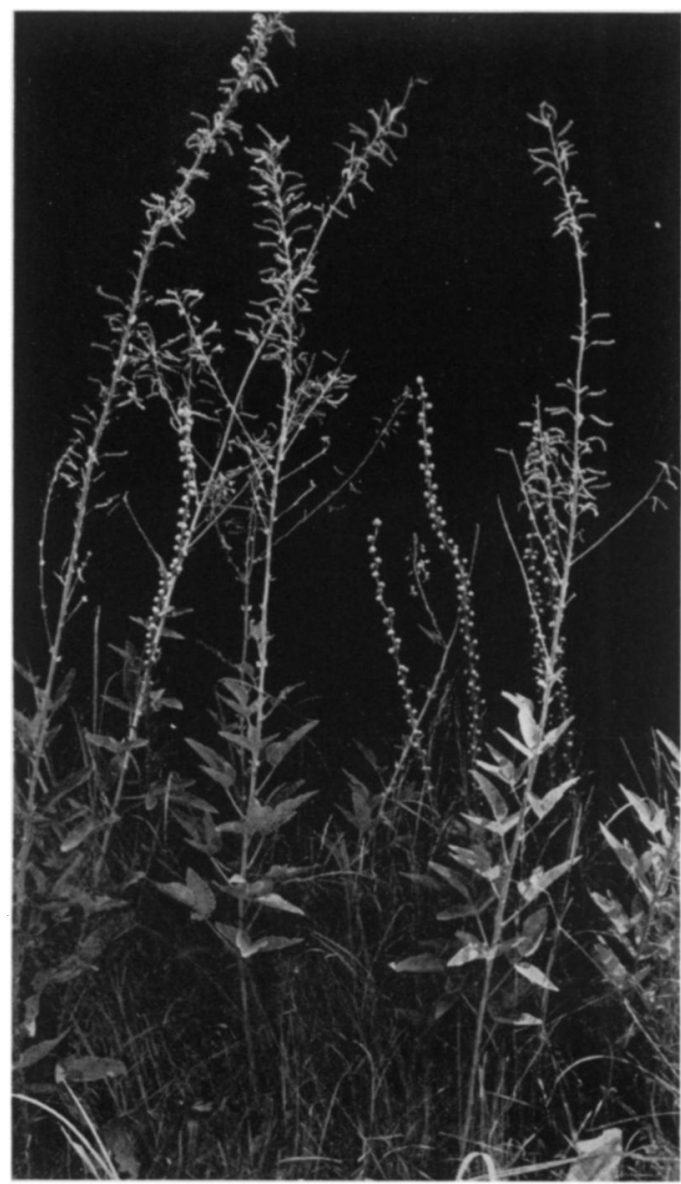

Fig. 34. Forbs in upland prairie at Oakland, Ia., on August 5. The tick-trefoil (Meibomia illinoensis) is about 5 feet high and the blazing star (Liatris scariosa) 44 inches.

\section{Abundance in 1940}

The species of native, long-lived forbs found at the end of the drought at the several prairie stations are given with their ratings in Table 5. The first section includes 59 species found at the Iowa stations only. They did not occur at any of the other 6 stations in true prairie. All but 6 species ranked as rare (5), infrequent (4), or common (3). Coreopsis palmata, Corylus americana, Euphorbia corollata, and Liatris pychnostachya alone ranked as societies

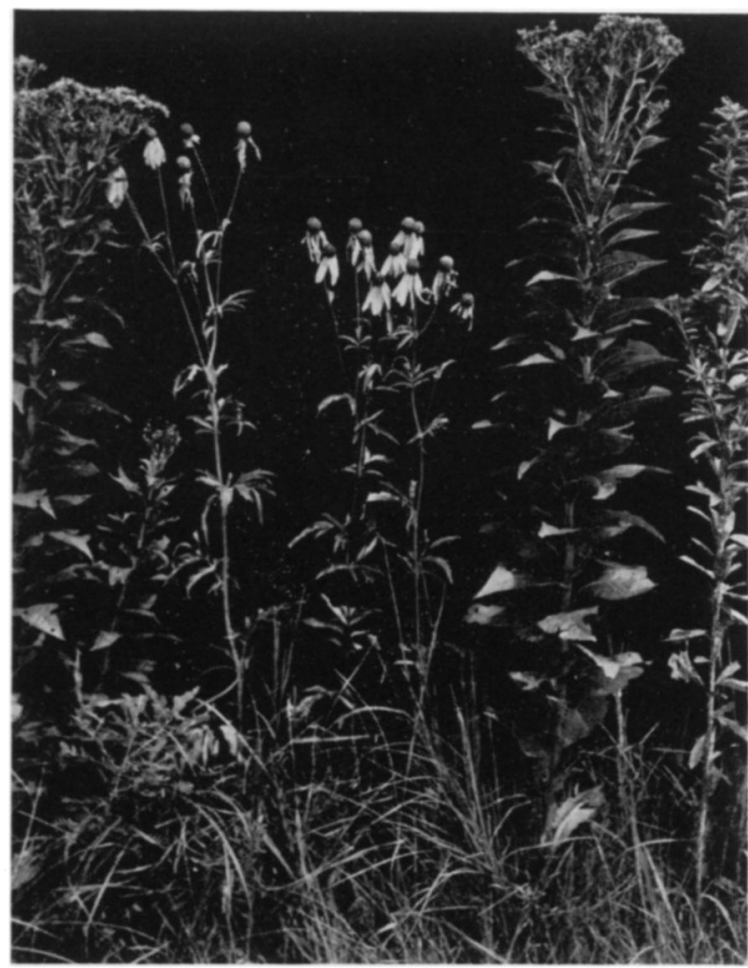

FIG. 35. Three characteristic forbs of western Iowa which on August 5 extended far above the 20 -inch grass level and attained heights of 45 to 50 inches. From right to left are Lespedeza capitata, Vernonia baldwini, and Lepachys pinnata.

of the first class (1). Corylus americana and Salix humilis are shrubs, but under annual mowing their growth simulates that of coarse forbs. In general, this list represents a group of the more mesic prairie forbs.

The second section includes a group of 36 species, mostly of more xeric habit, which were found in Iowa or Nebraska-Kansas bluestem prairies only. Here the

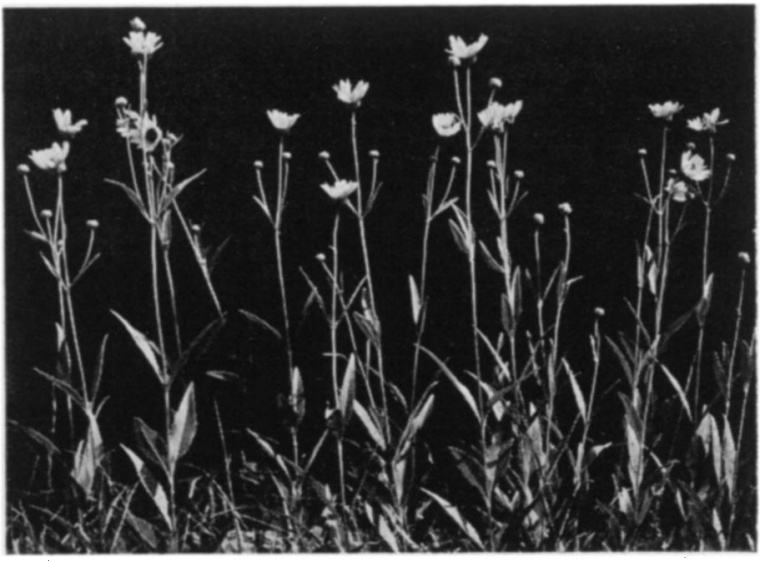

Frg. 36. Portion of a society of Helianthus rigidus on level upland in western Iowa on August 5. The plants are over 4 feet high. Bluestems at their base have been removed. 
TABLE 4. Most important forbs occurring at least at three of the several Nebraska-Kansas stations. Species are arranged after the lists of Weaver and Fitzpatrick in order of their general ecological importance in prairie. The rating for each species in each prairie is given for 1931, 1938, and 1940.

\begin{tabular}{|c|c|c|c|c|c|c|c|c|c|c|c|c|c|c|c|c|c|c|}
\hline \multirow{2}{*}{ Species } & \multicolumn{3}{|c|}{ Belleville } & \multicolumn{3}{|c|}{ Crete } & \multicolumn{3}{|c|}{ Valparaiso } & \multicolumn{3}{|c|}{ Carleton } & \multicolumn{3}{|c|}{ Clay Center } & \multicolumn{3}{|c|}{ Montrcse } \\
\hline & 1931 & 1938 & 1940 & 1931 & 1938 & 1940 & 1931 & 1938 & 1940 & 1931 & 1938 & 1940 & 1931 & 1938 & 1940 & 1931 & 1938 & 1940 \\
\hline Amorpha canescens ${ }^{1}$. & 1 & 2 & 1 & 1 & 1 & 3 & 1 & 1 & 1 & 2 & 1 & 1 & 1 & 1 & 1 & 1 & 2 & 2 \\
\hline Helianthus rigidus ${ }^{2} \ldots \ldots \ldots$ & 5 & 0 & 5 & 1 & 4 & 4 & 1 & 3 & 5 & & & & & & & & & \\
\hline Aster multiflorus........... & 1 & 4 & 3 & 1 & 1 & 1 & 2 & 1 & 1 & 1 & 3 & 5 & 1 & 3 & 5 & 1 & 2 & 4 \\
\hline Antennaria campestris ${ }^{2}$. . & 1 & 5 & 5 & 1 & 4 & 5 & $\overline{1}$ & 3 & 5 & 4 & 0 & 0 & 2 & 0 & 0 & 3 & 0 & 0 \\
\hline Erigeron ramosus ${ }^{2} \ldots . .$. & 1 & 4 & 4 & 1 & 2 & 3 & 1 & 3 & 1 & 1 & 0 & 4 & 1 & 5 & 3 & 5 & 5 & 4 \\
\hline Solidago glaberrima ${ }^{2}$. & 5 & 5 & 0 & 1 & $\overline{1}$ & 2 & 1 & 3 & 4 & 4 & 4 & 4 & 2 & 3 & 5 & 4 & 5 & 5 \\
\hline Psoralea argophylla ${ }^{2}$.. & 3 & 0 & 0 & 3 & 4 & 5 & 1 & 5 & 5 & 3 & 3 & 4 & 1 & 3 & 5 & 1 & 5 & 4 \\
\hline Petalostemon candidus ${ }^{2} \ldots$. & 4 & 5 & 4 & 3 & 5 & 5 & 1 & 4 & 5 & 4 & 5 & 5 & & & & & & \\
\hline Petalostemon purpureus ${ }^{2} \ldots .$. & 4 & 5 & 3 & 3 & 5 & 5 & 1 & 4 & 5 & 4 & 5 & 5 & & & & & & \\
\hline Solidago rigida ${ }^{2} \ldots \ldots \ldots \ldots$ & 5 & 5 & 5 & 3 & 5 & 0 & 3 & 5 & 0 & 4 & 5 & 0 & 1 & 0 & 0 & 5 & 0 & 0 \\
\hline Astragalus crassicarpus ${ }^{2} \ldots$. & 5 & 0 & 5 & 4 & 5 & 4 & 4 & 4 & 5 & 4 & 0 & 0 & 3 & 5 & 5 & 5 & 0 & 0 \\
\hline Liatris scariosa $a^{2} \ldots \ldots \ldots$ & & & & 5 & 0 & $\overline{5}$ & 3 & 5 & 5 & 5 & 0 & 0 & & & & & & \\
\hline Rosa arkansana ${ }^{2} \ldots \ldots$ & 3 & 3 & 4 & 2 & 3 & 4 & 5 & 5 & 4 & 4 & 1 & 2 & & & & 4 & 3 & 3 \\
\hline Kuhnia glutinosa ${ }^{1}$... & 3 & 4 & 5 & 5 & 5 & 0 & 4 & 3 & 3 & 5 & 3 & 3 & 3 & 5 & 5 & 4 & 3 & 2 \\
\hline Psoralea floribunda ${ }^{1} \ldots \ldots \ldots$ & & & & 1 & 1 & 1 & 5 & 5 & 5 & & & & & & & 5 & 0 & 0 \\
\hline Sisyrinchium angustifolium ${ }^{3}$ & 1 & 0 & 0 & 4 & 0 & 0 & & & & 4 & 0 & 0 & 2 & 0 & 0 & & & \\
\hline Liatris punctata ${ }^{1} \ldots . . . \ldots$ & 2 & 3 & 5 & & & & 3 & 4 & 3 & 5 & 5 & 4 & 5 & 5 & 4 & 4 & 3 & 3 \\
\hline Meibomia illinoensis ${ }^{2} \ldots$ & 5 & 5 & 0 & 4 & 4 & 5 & 5 & 0 & 5 & & & & & & & & & \\
\hline Artemisia gnaphalodes ${ }^{2}$. & 1 & 4 & 4 & 4 & 4 & 4 & 3 & 4 & 4 & 4 & 5 & 0 & 1 & 3 & 4 & 4 & 4 & 0 \\
\hline Solidago rigidiuscula ${ }^{3}$. & 2 & 0 & 0 & 5 & 0 & 0 & 3 & 0 & 0 & 4 & 0 & 0 & & & & 1 & 0 & 0 \\
\hline Achillea occidentalis ${ }^{2}$... & 4 & 0 & 4 & 5 & 5 & 5 & 4 & 0 & 0 & 4 & 0 & 0 & 5 & 0 & 0 & & & \\
\hline Senecio plattensis ${ }^{2} \ldots$ & 5 & 0 & 5 & 5 & 2 & $\check{5}$ & 5 & 4 & 0 & 2 & 0 & 0 & 2 & 0 & 0 & & & \\
\hline Lepachys columnifera ${ }^{2}$ & & & 4 & 5 & 0 & 0 & 4 & 0 & 0 & 5 & 5 & 0 & & & & 4 & 0 & 0 \\
\hline Callirhoe alcaeoides ${ }^{1} \ldots$ & 5 & 4 & 5 & & & & & & & 1 & 4 & 5 & 4 & 4 & 5 & 4 & 4 & 4 \\
\hline Physalis lanceolata $^{2} \ldots \ldots \ldots$ & 4 & 0 & 0 & 4 & 5 & 5 & 4 & 0 & 0 & 5 & 5 & 0 & 5 & 5 & 0 & 5 & 0 & 0 \\
\hline Lithospermum linearifolium ${ }^{1}$. & 5 & 5 & 5 & & & 5 & & 5 & 4 & & & 5 & 5 & 5 & 0 & 5 & 5 & 0 \\
\hline Hieracium longipilum ${ }^{2} \ldots \ldots$ & 5 & 0 & 0 & 5 & 5 & 5 & & & & & & & & & & 4 & 0 & 0 \\
\hline Delphinium virescens ${ }^{1}$... & & & 5 & 5 & 4 & 5 & & & & & & 5 & 5 & 0 & 0 & 5 & 4 & 0 \\
\hline Meriolix serrulata ${ }^{1} \ldots \ldots$ & 4 & 5 & 3 & & & & 4 & 5 & 5 & 5 & 5 & 5 & 5 & 5 & 5 & 5 & 0 & 0 \\
\hline Gentiana puberula ${ }^{1} \ldots .$. & & & & 5 & 5 & 5 & 5 & 5 & 5 & & & & 5 & 0 & 0 & & & \\
\hline Glycyrrhiza lepidota ${ }^{2} \ldots$ & 4 & 5 & 5 & 4 & 4 & 5 & 3 & 5 & 5 & & & & & & & 4 & 0 & 0 \\
\hline Vernonia baldwini ${ }^{1} \ldots$ & 4 & 4 & 5 & 4 & 4 & 5 & 3 & 5 & 4 & 5 & 5 & 5 & & 5 & 5 & 4 & 5 & 4 \\
\hline Cirsium undulatum ${ }^{1} \ldots .$. & 4 & $\overline{5}$ & 5 & & & 5 & & & & 5 & 0 & 0 & 4 & 4 & 4 & 4 & 0 & 4 \\
\hline 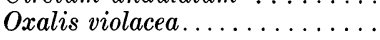 & & & 2 & 4 & 2 & 3 & & & 5 & 4 & 3 & 2 & & 1 & 3 & 4 & 5 & 1 \\
\hline
\end{tabular}

ranking is variable, but the occurrence is predominantly infrequent (4) or rare (5).

A final list of 36 xeric species was found at the western wheat grass prairies or (Psoralea floribunda and Tradescantia bracteata) at the Nebraska little bluestem stations only. Fourteen species were found only at the two westerly station groups. Four species, all very xeric-Allionia linearis, Gaura coccinea, Lygodesmia juncea, and Malvastrum coccineumwere found at the wheat grass stations only.

Average number of species at the three station groups from east to west was 85, 40, and 21, respectively. The scarcity of most species is shown by the fact that 75 percent of the listings were in classes 4 or 5 and only 12 percent in classes 1 and 2 .

The forbs at the three mixed-prairie stations and twelve others westward are listed in Table 6 . This group of 17 species includes all the long-lived forbs found. Kuhnia glutinosa, Aster multiflorus, and Liatris punctata occurred at all of the grassland station groups from Iowa westward. The species from Allionia linearis to Solidago mollis inclusive, except Psoralea tenuiflora, occurred at some wheat grass stations as well as in mixed prairie, but like the five remaining species, which except Sideranthus were found in mixed prairie only, they are distinctly more western in distribution and more xeric than some of the preceding. Only 1 or 2 species occurred at some stations and never more than 10 to 12 were found.

The lowest ebb of vegetation at these stations was reached in spring and early summer of 1940, following the great drought which extended through the fall and winter of 1939 . The ten most drought-resistant species (excepting the cacti) are each preceded by an asterisk. All could be found in 19381939 in nearly every range, not abundantly and always scattered, especially after some searching. But after the drought of 1939, only Malvastrum, Kuhnia, Psoralea, and Cirsium could be found after prolonged searching in favored spots; the rest were seen rarely. This explains the overwhelming number of low ratings (4 and 5) and, except for cacti, the rare occurrence of any species in abundance at any station.

The cause of drought resistance of these 10 species has not been studied specifically on a physiological basis. It may be found to be inherent in the protoplasm. The following observations, however, are pertinent. Nearly all of these species are deeply rooted and thus may utilize all available water throughout the soil to the depth of water infiltration. 
TABLe 5. Species and rating of forbs occurring at the end of the drought in upland bluestem prairies of Iowa, upland bluestem prairies of eastern Nebraska and Kansas, and in wheat grass prairies in eastern Nebraska and north-central Kansas.

1. Species Listed in Iowa Only

\begin{tabular}{|c|c|c|c|c|c|}
\hline Species & 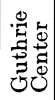 & ن & Species & 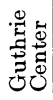 & 苞 \\
\hline Anemone cylindrica... & 4 & 5 & Hieracium scabrum. . & 5 & .. \\
\hline $\begin{array}{l}\text { Antennaria } \\
\text { plantaginifolia.. }\end{array}$ & 5 & 5 & 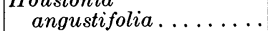 & & 4 \\
\hline A pocynum cannabinum & 5 & 4 & Hypoxis hirsuta... & 5 & \\
\hline A pocynum sibiricum... & 3 & 5 & Lepachys pinnata...... & 5 & 4 \\
\hline Asclepias pumila ${ }_{\text {. }}$... & 5 & $\because \dot{5}$ & $\begin{array}{l}\text { Leptandra virginica } \ldots \\
\text { Liatris pychnostachya }\end{array}$ & $\frac{4}{2}$ & $\begin{array}{l}4 \\
1\end{array}$ \\
\hline Asclepias verticillata.... & $\ddot{4}$ & 4 & Liatris squarrosa...... & 4 & $\begin{array}{l}1 \\
2\end{array}$ \\
\hline Aster laevis . . . . . . . & 5 & 5 & Lithospermum gmelini.. & 4 & 5 \\
\hline Aster sagittifolius & 3 & 3 & Meibomia canadensis... & 5 & 5 \\
\hline Aster sericeus... & 4 & 5 & Onosmodium & & \\
\hline Astragalus carolinianus & 5 & & hisxitissimum....... & 5 & \\
\hline Baptisia leucantha.... & 4 & $\dot{5}$ & Pedicularis canadensis. . & 4 & 4 \\
\hline Chamaecrista & 4 & & Phlox pilosa . . . . . . . & 4 & 4 \\
\hline fasciculata....... & $\stackrel{4}{2}$ & $\begin{array}{r}5 \\
4\end{array}$ & $\begin{array}{l}\text { Physalis heterophylla... } \\
\text { Physalis virginiana }\end{array}$ & $\begin{array}{l}5 \\
5\end{array}$ & \\
\hline $\begin{array}{l}\text { Comandra umbellata. } \\
\text { Coreopsis palmata... }\end{array}$ & 1 & 1 & & 5 & .. \\
\hline Corylus americana & 1 & & monspeliensis. & & 5 \\
\hline Drymocallis & & & Prunella vulgaris. & 5 & .. \\
\hline agrimonioides... & 4 & 3 & Pycnanthemum & & \\
\hline Equisetum arvense. . . & 5 & 5 & $\begin{array}{l}\text { Alexuosum } \\
\text { Salix humili }\end{array}$ & $\begin{array}{l}4 \\
4\end{array}$ & $\begin{array}{l}4 \\
4\end{array}$ \\
\hline $\begin{array}{l}\text { Eryngium } \\
\text { yuccifolium . . . . . . }\end{array}$ & 3 & 3 & $\mid \begin{array}{l}\text { Sallx } \\
\text { Senecio aureus............ }\end{array}$ & 4 & \\
\hline Eupatorium & & & Sieversia ciliata... & & \\
\hline & 5 & & Silphium laciniatum & 4 & \\
\hline Euphorbia corollata... & 1 & 1 & Solidago canadensis. & 4 & 4 \\
\hline Euthamia graminifolia & 5 & 4 & Solidago rigidiuscula & & 3 \\
\hline Fragaria virginiana. . & 5 & 5 & Steironema ciliatum. & 5 & 5 \\
\hline & 5 & 5 & Tradescantia & & \\
\hline Gaura parviflora. & $\dot{r}$ & 5 & occidentalis $\ldots \ldots \ldots$ & - & $\begin{array}{l}5 \\
4 \\
\end{array}$ \\
\hline $\begin{array}{l}\text { Geum album......... } \\
\text { Habenaria leucophaea . }\end{array}$ & $\begin{array}{l}5 \\
5\end{array}$ & $\ddot{z}$ & $\begin{array}{l}\text { Vernonia fasciculata.... } \\
\text { Viola papilionacea .... }\end{array}$ & 4 & 4 \\
\hline Helianthus & & & Viola pedata ..... & 3 & \\
\hline $\begin{array}{c}\text { grosseserratus..... } \\
\text { Heuchera americana. }\end{array}$ & 4 & 4 & Viola pedatifida . . . & 4 & 5 \\
\hline Heuchera americana. & 4 & 3 & Zizia aurea ........ & 5 & 3 \\
\hline
\end{tabular}

2. Species Listed in Bluestem Prairies Only

\begin{tabular}{|c|c|c|c|c|c|c|c|c|}
\hline Species & 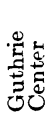 & ن & 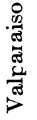 & $\begin{array}{l}\stackrel{ \pm}{0} \\
\text { Uू }\end{array}$ & 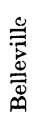 & 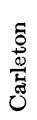 & 密莺 & 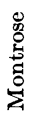 \\
\hline Achillea occidentalis. & 5 & 2 & . & 5 & 4 & . & . & . \\
\hline Allium nuttallii. .... & & & & & $\underline{4}$ & .. & .. & .. \\
\hline Antennaria campestris..... & 3 & 1 & 5 & 5 & 5 & . & . & . \\
\hline A pocynum androsaemifolium & . & . & .. & 5 & & . & . & .. \\
\hline Asclepias amplexicaulis.... & $\ddot{5}$ & $\ddot{4}$ & $\because$ & $\ddot{5}$ & $\begin{array}{l}5 \\
. .\end{array}$ & $\cdots$ & $\because$ & · \\
\hline $\begin{array}{l}\text { Asclepias tuberosa } \ldots \ldots \ldots \\
\text { Aster oblongifolius . . . . . }\end{array}$ & & & $\ddot{5}$ & & $\begin{array}{l}. . \\
\text { a }\end{array}$ & $\ddot{0}$ & 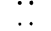 & .. \\
\hline Baptisia leucophaea....... & 4 & 4 & . & 5 & & . & .. & . \\
\hline Blephariglottis leucophaea.. & 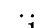 & . & 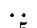 & 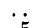 & 2 & .. & . & . \\
\hline $\begin{array}{l}\text { Ceanothus pubescens........ } \\
\text { Cogswellia daucifolia }\end{array}$ & 1 & 1 & $\begin{array}{l}5 \\
5\end{array}$ & b & .. & $\because$ & $\because$ & . \\
\hline 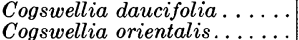 & $\cdots$ & $\cdots$ & & $\cdots$ & 4 & $\because$ & $\because$ & : \\
\hline Echinacea pallida........... & 4 & 1 & 3 & 5 & .. & $\because$ & $\because$. & ... \\
\hline Equisetum laevigatum..... & 4 & 5 & 5 & 5 & . & . & . & .. \\
\hline Erythronium mesochoreum. & & & 4 & $\because$ & - & .. & $\cdot$ & \\
\hline Gentiana puberula....... & 5 & 4 & 5 & 5 & & . & . & . \\
\hline Glycyrrhiza lepidota... & 4 & 5 & 5 & 5 & 5 & . & . & . \\
\hline Hieracium longipilum. & 2 & 3 & .. & 5 & & . & . & .. \\
\hline Helianthus maximiliani . . . & 5 & 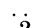 & $\because$ & 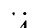 & 5 & . & . & . \\
\hline Helianthus rigidus. . . . . & 1 & 2 & $\begin{array}{l}5 \\
3\end{array}$ & 4 & & $\cdots$ & . & - \\
\hline Heliopsis scabra...... & 4 & 4 & 3 & $\cdots$ & 4 & $\cdots$ & “ & $\cdots$ \\
\hline $\begin{array}{l}\text { Lepachys columnifera } \ldots \ldots \\
\text { Lespedeza capitata } \ldots \ldots\end{array}$ & $\begin{array}{l}4 \\
5\end{array}$ & $\begin{array}{l}3 \\
5\end{array}$ & . & & $\frac{4}{5}$ & $\begin{array}{l}\cdots \\
\cdots\end{array}$ & $\ddot{\cdots}$ & .. \\
\hline Liatris scariosa.......... & 3 & 3 & 5 & 5 & . & .. & . & .. \\
\hline Meibomia illinoensis. . & 4 & 5 & 5 & 5 & .. & . & . & . \\
\hline Mesadenia tuberosa... & 5 & 5 & . & 5 & . & . & . & . \\
\hline Nabalus asper....... & . & . & . & 5 & . & . & . & . \\
\hline Onagra biennis...... & . & . & . & 5 & $\ddot{3}$ & . & .. & - \\
\hline $\begin{array}{l}\text { Opuntia humifusa ......... } \\
\text { Petalostemon purpureus... }\end{array}$ & $\dot{5}$ & 4 & $\ddot{5}$ & 5 & $\begin{array}{l}3 \\
4\end{array}$ & $\begin{array}{l}\cdots \\
\cdots\end{array}$ & $\begin{array}{l}\cdots \\
\cdots\end{array}$ & $\begin{array}{l}. \\
\text {. }\end{array}$ \\
\hline Physalis lanceolata... & & & & & & & 1 & \\
\hline Rhus rydbergii. ............ & 4 & 3 & 3 & . & 4 & . & . & \\
\hline Silphium integrifolium..... & 2 & 3 & 5 & .. & . & .. & . & . \\
\hline 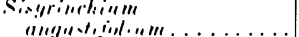 & 3 & 4 & & & & & . & \\
\hline Solidago altissima... & & 4 & .. & 5 & 5 & 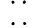 & .. & \\
\hline Solidago rigida. . & 4 & 4 & .. & & 5 & & . & \\
\hline
\end{tabular}

3. Species Found in Wheat Grass Prairies

\begin{tabular}{|c|c|c|c|c|c|c|c|c|}
\hline Species & 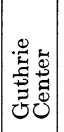 & 莒 & 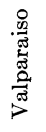 & 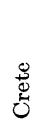 & 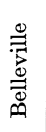 & 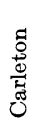 & 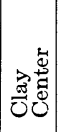 & 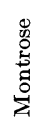 \\
\hline 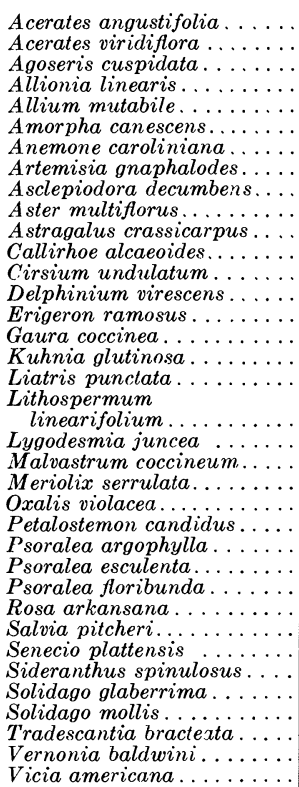 & 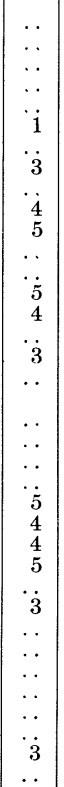 & 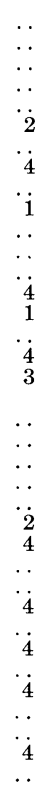 & 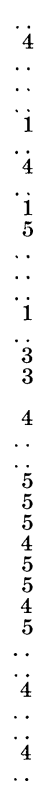 & 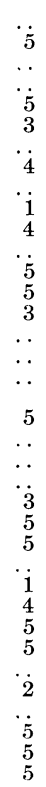 & $\begin{array}{r}\ddot{5} \\
5 \\
\\
5 \\
. . \\
\ddot{3} \\
2 \\
3 \\
\ddot{5} \\
\ddot{4} \\
5 \\
5 \\
5 \\
\ddot{5} \\
5 \\
4 \\
5\end{array}$ & $\begin{array}{c}5 \\
. \\
\because \\
5 \\
2 \\
5 \\
4 \\
. \\
\because \\
2 \\
\cdots \\
\because \\
\ddot{4} \\
\cdots \\
\because \\
5 \\
5\end{array}$ & $\begin{array}{l}5 \\
5 \\
.5 \\
5 \\
\ddot{1} \\
2 \\
4 \\
5 \\
5 \\
5 \\
5 \\
4\end{array}$ & \begin{tabular}{c}
$\ddot{2}$ \\
1 \\
$\cdots$ \\
$\ddot{4}$ \\
$\ddot{4}$ \\
4 \\
$\ddot{4}$ \\
5 \\
2 \\
3 \\
. \\
\hdashline \\
5 \\
$ن$
\end{tabular} \\
\hline Total number of species. & 87 & 83 & 35 & 41 & 45 & 19 & 24 & 21 \\
\hline
\end{tabular}

Most have storage organs consisting of thick roots or underground stems which promote early growth and rapid recovery during periods with moist soil. Most of these species do not have an abundance of foliage and with the oncoming of drought, the transpiring surface is greatly reduced by loss of many

TABLE 6. Species and ratings of long-lived forbs occurring in representative ranges of 9 counties in western Kansas. Many of these ranges had not been grazed for 3 or more years, since the cover was so greatly reduced by drought or dust.

\begin{tabular}{|c|c|c|c|c|c|c|c|c|c|c|c|c|c|c|c|}
\hline Species & $\mid \begin{array}{l}0 \\
0 \\
0 \\
0 \\
0 \\
0 \\
0 \\
0 \\
0\end{array}$ & 空 & 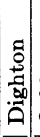 & $\frac{3}{\frac{3}{\pi}}$ & 总 & $\begin{array}{l}0 \\
0 \\
0 \\
+ \\
0 \\
0 \\
0\end{array}$ & 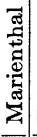 & & 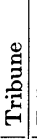 & & 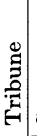 & 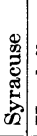 & 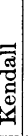 & $\begin{array}{l}0 \\
\\
0 \\
0 \\
0 \\
0 \\
0\end{array}$ & $=4$ \\
\hline *Kuhnia glutinosa. & 5 & 5 & 5 & 5 & 5 & . & .. & . & . & .. & . & & . & 3 & 3 \\
\hline Aster multiflorus... & . & 5 & & . & & . & .. & . & . & .. & .. & .. & . & 4 & 4 \\
\hline *Cirsium undulatum. & .. & 4 & 5 & 5 & 5 & .. & .. & .. & 4 & 4 & 5 & & .. & 4 & 4 \\
\hline Lepachys columnifera.... & . & .. & 3 & 5 & 4 & . & .. & . & 5 & & 3 & 5 & & 5 & 5 \\
\hline *Lygodesmia juncea ..... & 4 & .. & & .. & .. & .. & .. & .. & .. & & . &. & . & & \\
\hline Opuntia humifusa... & 3 & 1 & & 2 & 3 & 3 & 3 & 2 & 2 & & 3 & 2 & & 2 & \\
\hline *Liatris punctata. & . & 5 & $\cdot$ & .. & .. & .. & .. & . & .. & . & 5 & 5 . & . & . & \\
\hline * Allionia linearis... . & 5 & 4 & 5 & . & 5 & 5 & .. & . & . & 5 & 5 & . & . & 5 & 5 \\
\hline *Gaura coccinea ....... & 4 & 4 & 4 & $\cdot$ & 5 & 5 & . & . & . & . & 4 & $\cdot$ & . & 5 & 4 \\
\hline *Malvastrum coccineum... & 1 & 2 & 4 & 5 & 3 & 4 & 5 & & 4 & 3 & 2 & 3 & 4 & $\cdot$ & 3 \\
\hline *Psoralea tenuifiora. .... & 5 & 5 & 5 & 5 & 3 & 5 & .. & . & . & . & 4 & & . & 4 & 3 \\
\hline *Solidago mollis........ & 1 & & .. & . & .. & . & .. & . & . & . & . & . & . & . & \\
\hline Astragalus mollissimus . & . & & & . & . & .. & . & . & . & . & . & . & & . & 5 \\
\hline Gutierrezia sarothrae.... & & & .. & . . & 5 & 5 & . & . & & . & & & & 5 & \\
\hline Linum compactum. . . & . & 4 & 5 & 5 & 5 & & . & & 5 & & 5 & & & 5 & \\
\hline Opuntia fragilis.... & $\cdot$ & & . . &. & .. & .. & .. & . & . & & .. & & 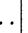 & 5 & \\
\hline *Sideranthus spinulosus & 5 & 4 & 5 & 5 & 5 & 4 & $\cdots$ & & 3 & 5 & & & & 5 & 5 \\
\hline
\end{tabular}




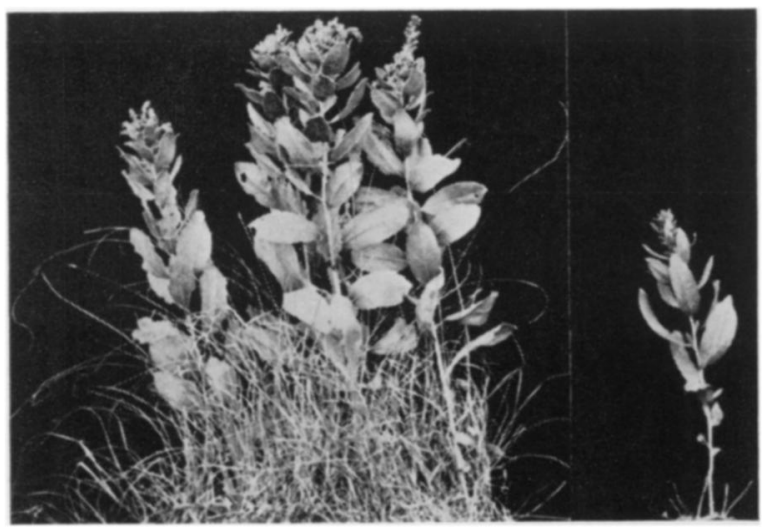

Fig. 37. Solidago mollis before the great drought (left). The several stems of the plant are 18 inches high. At the right is the single stemmed drought form 10 inches tall. Hays, Kan., June 30.

leaves. Malvastrum coccineum possesses all of these characteristics. It begins growth early, loses most of its leaves with the advent of drought, and the few that remain curl during the dry period. It is the most drought-resistant of all.

The dwarfed condition of these drought-resistant survivors was very marked. This can best be appreciated when the drought form is compared directly with plants of normal stature preceding the dry years (Figs. 37 to 40 ).

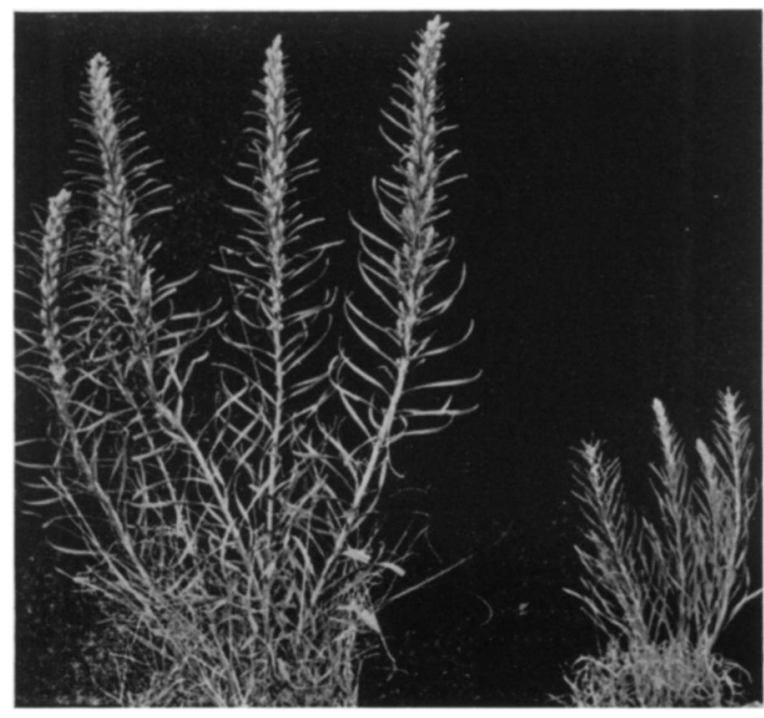

Fig. 38. Liatris punctata of normal development (left) and drought form (right). They are 21 and 11 inches tall, respectively. Hays, Kan., June 30.

\section{Abundance in Sampling Areas}

The actual abundance of forbs at each of the several stations was ascertained in 1940 . This was accomplished by counting the long-lived forbs in circular areas 50 feet in diameter. Two circles in each prairie were located in typical sites representative of the prairie as a whole. Thus, plants on 3,927 square feet of soil at each station were carefully examined. Since it was impossible to distinguish individual plants of many species with branched rhizomes, and since drought-stricken plants usually had fewer stems than normal ones, the number of stems rather than the number of plants was counted. This could be done accurately by separating the circle into small sectors and examining each individually.

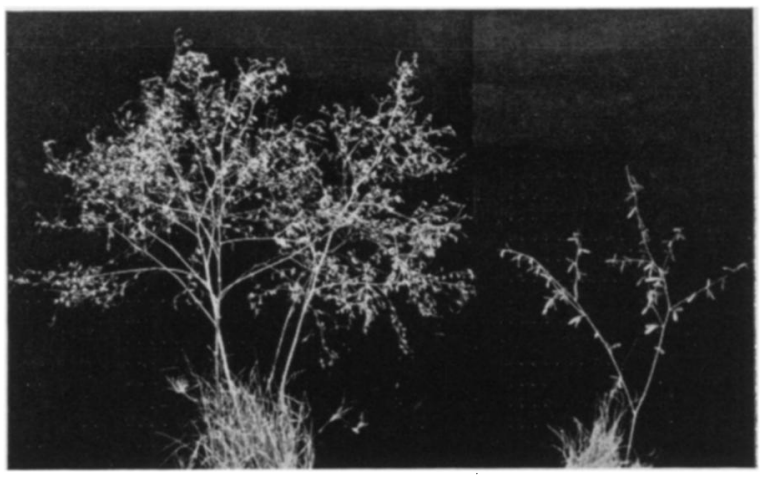

Fig. 39. Psoralea tenuiflora was perhaps the most widely spread legume of mixed prairie before the drought (left). Its usual height was about 2 feet. The single-stemmed drought form (right), taken on July 30,1940 , is only 18 inches high.

Thirty-eight species were listed at the Iowa stations only. For convenience, they are placed separately in Table 7. Aster sericeus, Coreopsis palmata, Euphorbia corollata, Liatris squarrosa, and Senecio aureus were especially abundant, the second being represented by 11,700 stems at one station.

The second section adds 18 species found in the bluestem prairies only. Species listed in section 3 are undoubtedly more xeric. In this group, three species (Amorpha canescens, Aster multiflorus, and Kuhnia glutinosa) occurred in very great numbers, but much more sparsely in wheat grass than in bluestem prairies. Number of stems of Amorpha varied from an average of 8,497 per station in Iowa to 3,904 in the bluestem prairies westward, but decreased to 610 in the wheat grass prairies. Similar numbers for Kuhnia are 1,036, 59, and 101. Aster increased in
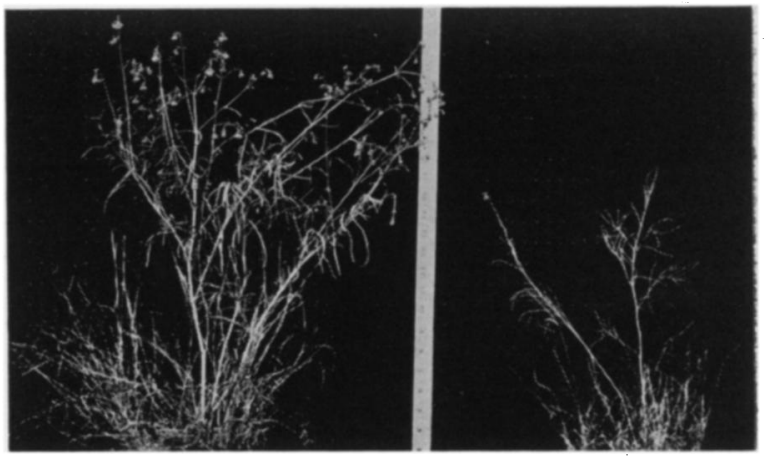

Fig. 40. Narrow-leaved four-o'clock (Allionia linearis) of normal size (left) and drought form (right). The one is 26 inches tall, the other 18 inches. 
the western bluestem group, but practically disappeared in the wheat grass.

Average total numbers of species and stems at the Iowa stations, the Nebraska-Kansas bluestem stations, and in the wheat grass prairies were 47 and 27,875; 19 and 7,109 ; and 11 and 1,083, respectively. Thus the number of species at the western bluestem stations was reduced 60 percent and the number of stems 75 percent. Further reduction from the more westerly bluestem prairies to wheat grass prairies amounted to 42 percent in species but 85 percent in number of stems.

TABLE 7. Species and number of stems of forbs occurring in two circles 50 feet in diameter in bluestem prairies of Iowa, bluestem prairies of eastern Nebraska and Kansas, and in wheat grass prairies in eastern Nebraska and north-central Kansas.

\begin{tabular}{|c|c|c|c|c|c|}
\hline Species & Anita & $\begin{array}{l}\text { Oak- } \\
\text { land }\end{array}$ & Species & Anita & $\begin{array}{l}\text { Oak- } \\
\text { land }\end{array}$ \\
\hline Anemone canadensis. & 14 & & Liatris squarrosa.... & 2,100 & 17 \\
\hline Anemone cylindrica. & & 30 & Lithospermum & & \\
\hline $\begin{array}{l}\text { Asclepias } \\
\text { amplexicaulis..... }\end{array}$ & & & 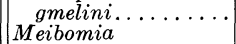 & & 11 \\
\hline Aster azureus....... & 121 & & illinoensis....... & 15 & 240 \\
\hline Aster laevis. ....... & 13 & 655 & Mesadenia tuberosa & & 2 \\
\hline Aster oblongifolius. . & & 14 & Onosmodium & & \\
\hline Aster sagittifolius . . & 12 & & occidentale. & 14 & 41 \\
\hline Aster sericeus. . . . . & 177 & 1,155 & Pedicularis & & \\
\hline Ceanothus pubescens. & & 735 & canadensis. & 87 & \\
\hline $\begin{array}{l}\text { Chamaecrista } \\
\text { fasciculata } \ldots \ldots . . .\end{array}$ & 135 & & $\begin{array}{l}\text { Petalostemon } \\
\text { purpureus. }\end{array}$ & 220 & 61 \\
\hline $\begin{array}{l}\text { Coreopsis palmata... } \\
\text { Drymocallis }\end{array}$ & 11,700 & 417 & $\begin{array}{l}\text { Phlox pilosa......... } \\
\text { Physalis }\end{array}$ & 14 & 17 \\
\hline agrimonioides.... & & 4 & heterophylla ...... & 14 & 16 \\
\hline Equisetum & & & Physalis lanceolata.. & 195 & 9 \\
\hline $\begin{array}{l}\text { Laevigatum ........ } \\
\text { Eryngium }\end{array}$ & 203 & 14 & $\begin{array}{l}\text { Physalis longifolia. } \\
\text { Senecio aureus...... }\end{array}$ & 1,350 & 30 \\
\hline yuccifolium ..... & & & Silphium & & \\
\hline Euphorbia corollata. & 3,495 & 510 & laciniatum... & 27 & 13 \\
\hline $\begin{array}{l}\text { Fragaria virginiana. } \\
\text { Gaura parviflora.... }\end{array}$ & & $\begin{array}{l}63 \\
19\end{array}$ & $\begin{array}{l}\text { Sisyrinchium } \\
\text { angustifolium and }\end{array}$ & & \\
\hline Lepachys pinnata... & & $7 \|$ & $\|_{\text {S. campestre..... }}$ & 32 & 15 \\
\hline $\begin{array}{l}\text { Lespedeza capitata... } \\
\text { Liatris }\end{array}$ & 29 & & & 61 & \\
\hline pychnostachya.... & 01 & & Voola pedata & 135 & \\
\hline Liatris scariosa... & 316 & 44 & Viola pedatifida & 641 & 195 \\
\hline
\end{tabular}

2. Species Found in Bluestem Prairies Only

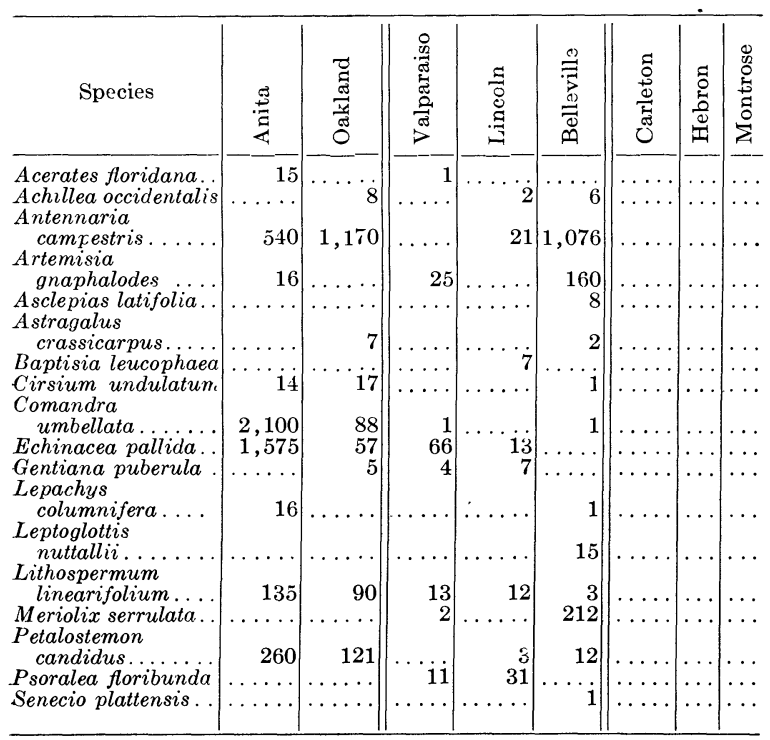

3. Species Found in Wheat Grass Prairies

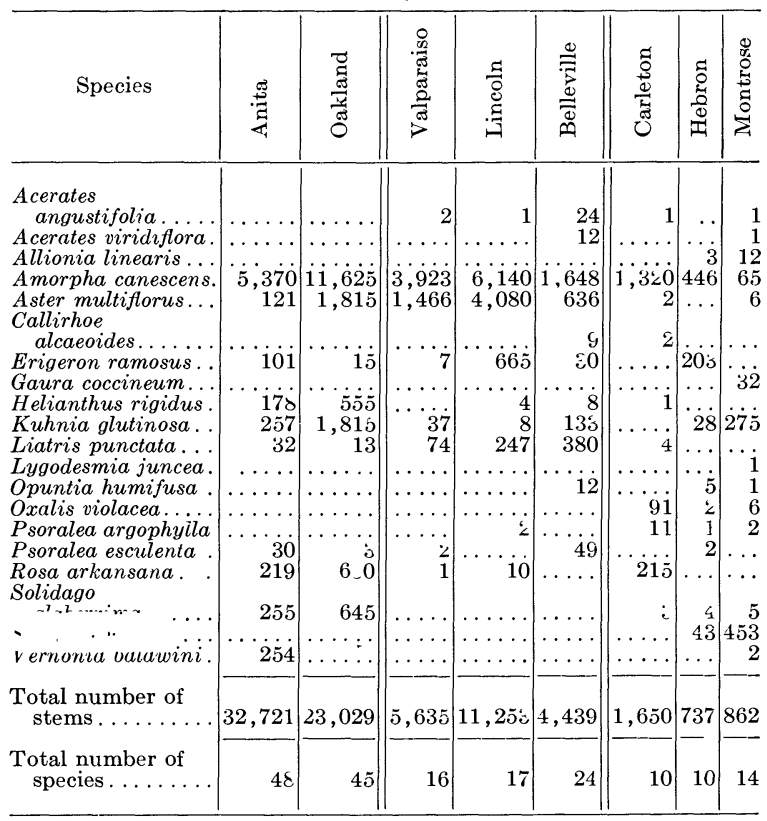

Forbs at Hays and Dighton, and at 12 other stations in western Kansas where originally the vegetation was similar, are listed in Table 8. Eighteen species include all of the native forbs found (Figs. 41 and 42). The number of species per station ranged from 1 to 14 with an average representation of only 5. This occurred despite the fact the circles were twice the diameter of those used previously, and the area four times as great. The scarcity of forbs in both kinds and numbers together with their extremely dwarfed stature is impressive. One marvels,

TABLE 8. Species and number of stems of forbs occurring in two circles each 100 feet in diameter at each of several stations located in 10 counties in western Kansas. Sometimes 2 or 3 different prairies were sampled within 15 miles of one town.

\begin{tabular}{|c|c|c|c|c|c|c|c|c|c|c|c|c|}
\hline Species & 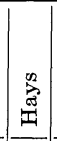 & 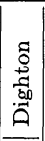 & $\mid \begin{array}{l}0 \\
0 \\
0 \\
0 \\
0 \\
0 \\
z \\
z\end{array}$ & 咅 & & 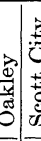 & & & & 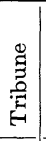 & & 㐘 \\
\hline Allionia linearis........ & & 20 & 8 & 3 & & 2 . & & . & 2 & & & $\begin{array}{lll}. & 4 & \end{array}$ \\
\hline Ambrosia psilostachya... & 134 & & $\ldots$ & & & & . & & & & & \\
\hline Aster multiflorus..... & & & $\ldots$ & & & & & & & & & 60 \\
\hline Astragalus lotiflorus... & & & $\ldots$ & & & & & . & & & 54 & 5 \\
\hline Astragalus mollissimus. & & & 8 & & & & & & & & & \\
\hline Cirsium undulatum.... & 2 & & & & & & & 4 & & & & 12 \\
\hline Gaura coccinea..... & & 36 & 36 & &. & & & & & 144 & & 12 \\
\hline Gutierrezia sarothrae. & & ... & & & & & & & & & & 2 \\
\hline Kuhnia glutinosa.... & & $\cdots$ & 24 & & 4 & 1. & & & & & & 52 \\
\hline Lepachys columnifera. & 15 & 22 & 12 & & se & 4. & & & & 204 & & 2 \\
\hline Lepachys tagetes...... & & & & & . &. & & & & 165 & & 30 \\
\hline Linum compactum... & 2 & & & & & $2 .$. & & 6 & & 20 & & 4 \\
\hline Malvastrum coccineum & $\left.190\right|_{2}$ & 205 & 242 & & 14 . &. & & 48 & & 160 & $12 \mid 10$ & \\
\hline Opuntia fragilis....... & $\ldots$ & & & & 6 & & & .. & & & ..... & 2 \\
\hline Opuntia humifusa...... & $\ldots$ & & & 7 & 6 & 4 . . & & & & & 14 & \\
\hline $\begin{array}{l}\text { Polygonum } \\
\quad \text { ramosissimum........ }\end{array}$ & & & & & & & & & & & & \\
\hline Psoralea tenuiflora...... & 62 & & 296 & 1 & 4 & 412 & & 2 & & 12 & & 10 \\
\hline Sideranthus spinulosus.. & & & 24 & 3 & & & & 18 & & & & . 6 \\
\hline
\end{tabular}




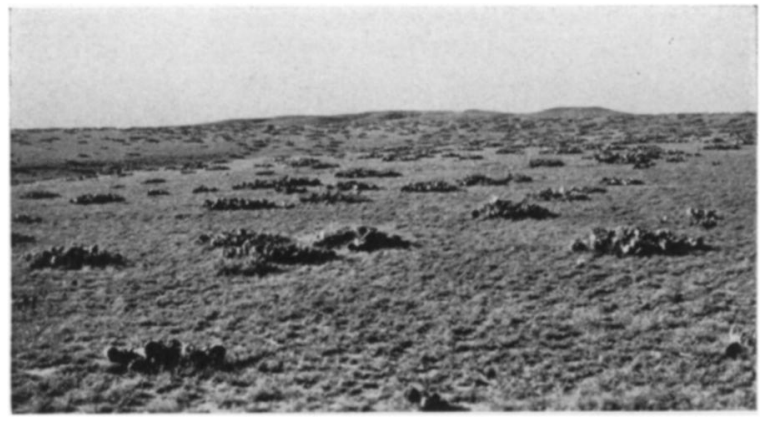

FIG. 41. Prairie near Ellis, Kan., in which non-grassy vegetation except cactus is absent. Basal cover of the short grasses is only 15 percent but the interspaces are largely occupied by little barley, peppergrass, and other weeds.

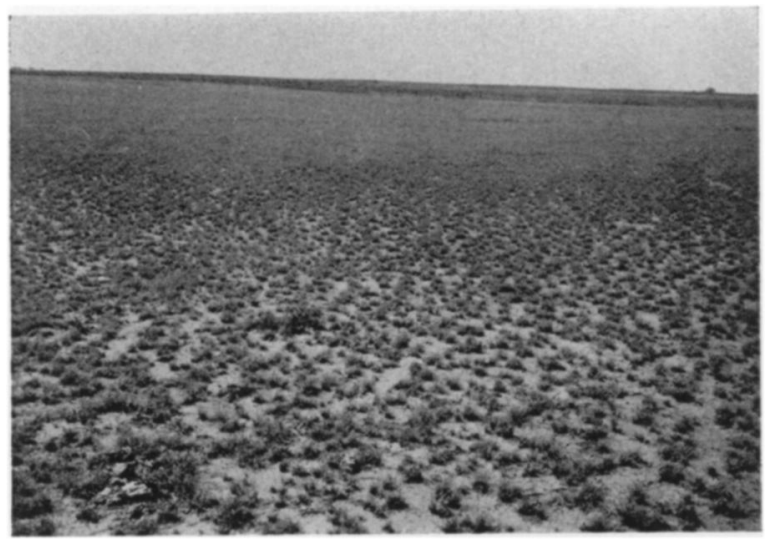

Fig. 42. General view of range near Dighton, Kan., with a characteristic open stand of grasses and almost complete absence of native forbs since the great drought.

however, not so much at the paucity of species and the thinly stretched web of life, as at the fact that any vegetation escaped the terrible drought and endured.

\section{Predrought and Post-drought Distribution}

The effects of the several years of drought upon the normal occurrence and abundance of the most important long-lived forbs of uplands is presented schematically in Table 9 . The group that maintained approximately its predrought abundance consists of only 5 species, none of which occurred in mixed prairie. Plants that decreased in abundance constitute a list of 41 species, 8 of which range far westward. It is of interest that all maintained their usual abundance in Iowa, and all but 5 decreased in eastern Kansas and Nebraska. Among the 11 species ranging into mixed prairie also, 4 decreased and 7 disappeared. Only one species of this group, Astragalus crassicarpus, persisted, but in numbers greatly decreased, in the plains disclimax.

Of species mostly of mixed prairie and short-grass plains disclimax, 28 are listed. Three persisted in normal numbers-two drought-escaping species of
TABLE 9: Most important species of forbs of uplands, other than annuals, and exclusive of deep, moist ravines or of species confined to rocky outerops, sand, or other local habitats. General predrought distribution is shown by light line. Present distribution in approximately normal numbers is shown by heavy line. A broken line indicates presence in decreased abundance, and plus signs signify a great increase in abundance. Where no line occurs other than the light one, the plants have disappeared.

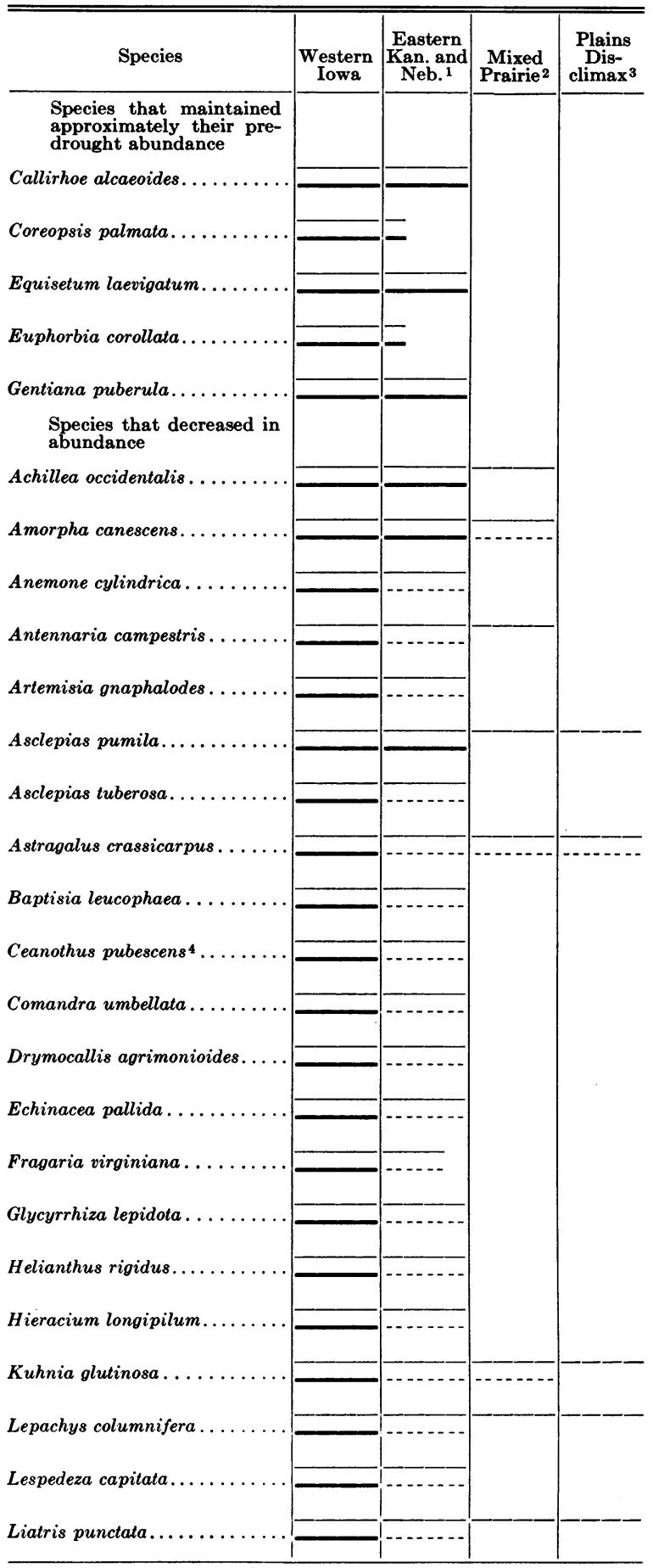


TABLe 9 (Continued).

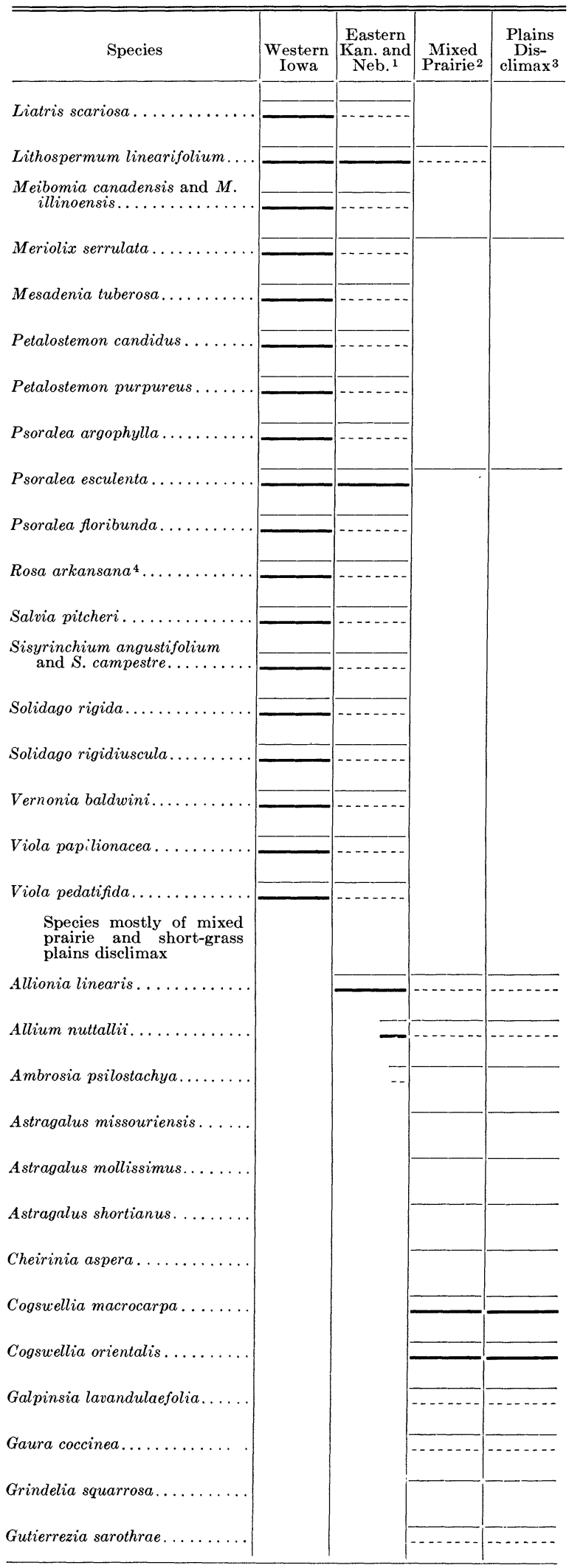

TABle 9 (Continued).

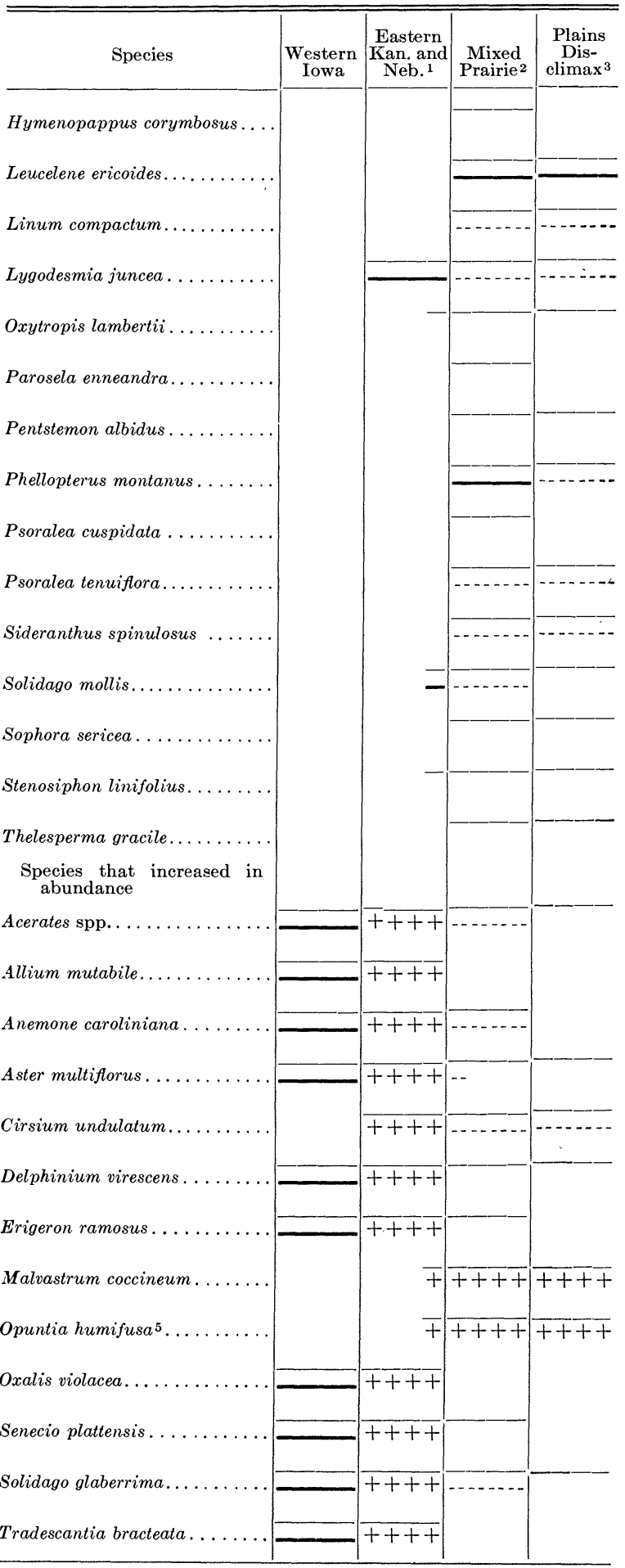

Eastern one third of Nebraska and eastern half of northern Kansas. ${ }^{2}$ West of Nelson, Nebraska, and Montrose, Kansas, to meridian $100.5^{\circ}$.

${ }^{3} \mathrm{~K}$ ansas and eastern Colorado west of $100.5^{\circ}$ meridian.

${ }^{4}$ Shrub which behaves as a forb under annual mowing.

${ }_{5}$ Also $O$. macrorrhiza. All of the cacti have increased more or less. 


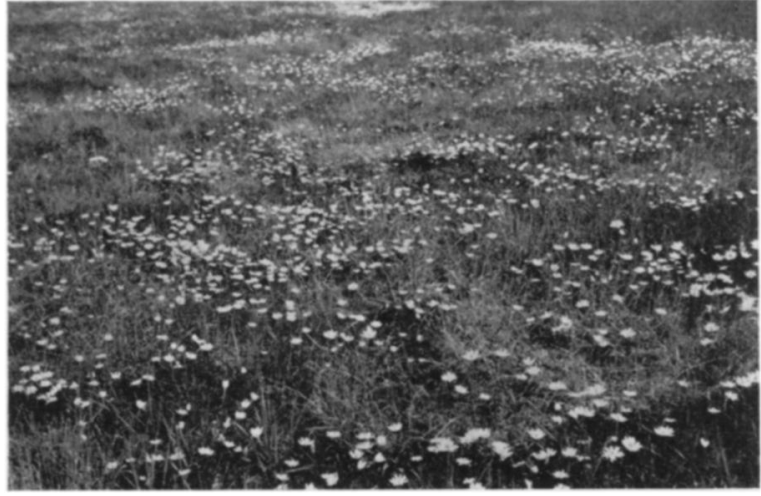

Fig. 43. Anemone caroliniana has greatly increased its numbers as a result of drought and bared soil. Montrose, Kan., May, 1940.

Cogswellia, and Leucelene ericoides. Fourteen species disappeared as drought continued, and the remaining all lost heavily in numbers.

The last group includes the most important species that have increased somewhere throughout the grassland during drought. The remarkable ability of certain plants, formerly of little importance, to invade the areas bared by drought is of much interest. Anemone caroliniana has spread thickly over wide areas (Fig. 43). During certain springs the soil was so dry that the plants were only 2 inches high and failed to flower, but when the soil was moist as many as 65 blossoms, often 2 inches in diameter, occurred per square meter. The naked flower stalks were sometimes 8 to 10 inches tall.

Oxalis violacea frequently formed circular patches 20 feet in diameter in which the foliage, 2 to 3 inches tall, completely concealed the soil. Like the windflower, it grew best in mellow, bared soil and also between the mats of blue grama, but practically never in dense stands of wheat grass (Fig. 44).

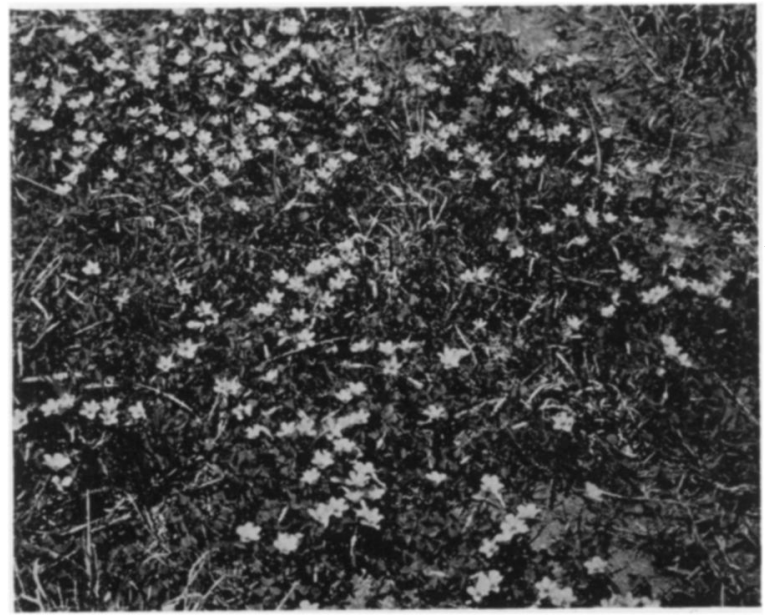

Fig. 44. Characteristic pateh of Oxalis violacea. Like the windflower, it has efficient underground organs of food accumulation and escapes drought by early growth in spring. Nelson, Neb., May 10, 1940.
Tradescantia bracteata, a species with fleshy roots, was common in patches of variable size, the largest observed being about two acres. Plants grew thickly and, like the preceding, were at a maximum in 1940 .

The bulbs of Allium mutabile thickly filled the soil over wide areas, even where a fairly good sod remained (Fig. 45). Westward, dense patches of $A$. nuttallii of great extent made beautiful the landscape in spring and early summer. Acerates, Aster multiflorus, Cirsium undulatum, Malvastrum coccineum, and Solidago glaberrima all have underground stems where much food is stored. Erigeron ramosus

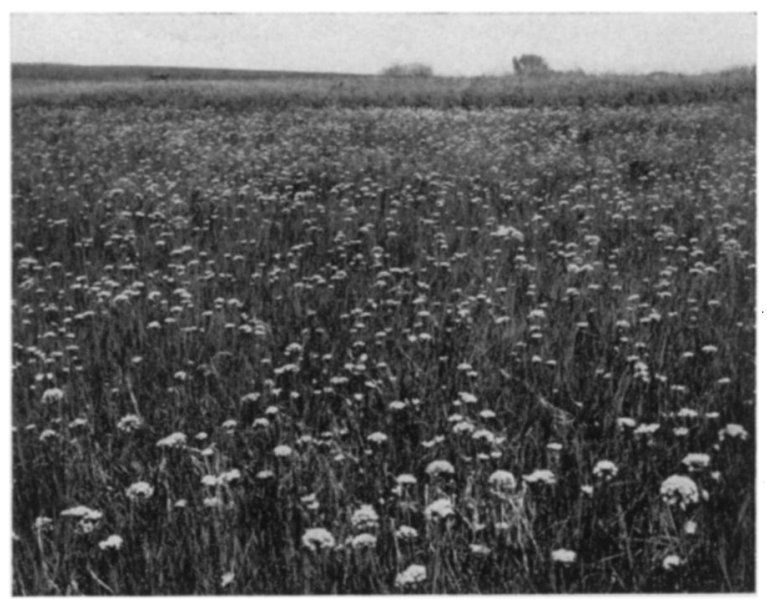

Fig. 45. A dense stand of Allium mutabile in bluestem prairie near Jamaica, Neb. Several species of this bulbous forb spread widely during the drought. June $10,1939$.

is a winter annual. The thick-rooted larkspur (Delphinium virescens) has increased greatly in abundance, and in places these usually solitary plants were rather closely grouped. All these species have been favored by a marked decrease in competition with other prairie plants. Many evade atmospheric drought by growing only in spring. Others, as Malvastrum, Aster, and Solidago, are very drought-resistant, the aster and goldenrod resuming growth in autumn, if rains come, after the tops have been completely killed by summer drought.

\section{RESURVEY OF UNDERGROUND PLANT PARTS}

A resurvey of underground plants parts should be prefaced by a brief statement concerning the soil, the previous depth and distribution of the roots of prairie plants, and the effects of drought in modifying the conditions of the soil.

\section{The SoIL}

From the Prairie soil of Iowa to the Chernozem of the western portion of true prairie, rich, deep, black, fertile, silt-loam soils prevail. The mellow, granular, dark-colored topsoil, enriched by thousands of generations of grasses, extends usually to depths of 12 to 20 inches. Beneath is a zone with higher clay con- 
tent and lighter color, which extends to a depth usually of 3 to 4 feet. When dry, this clay-rich soil shrinks considerably and cleaves into vertical columns (technically prisms), often 2 to 4 inches in width and of variable length -4 to 12 or more inches. Vertical cracks and some horizontal ones result. These are usually only a few millimeters in width but in extreme drought are sometimes 2 centimeters wide. Inderlying the soil (solum) is the parent material. It is often yellowish or at least lighter in color than the solum, partly because of its lower content of organic matter and partly because it is rich in lime. In Iowa and eastern Nebraska (Prairie soils) there is no lime layer, but in the Chernozem it is found first at 5 to 6 feet in depth but becomes shallower westward where a lime layer often 6 to 18 inches thick occurs. Except for rare rock outcrops, the parent material or massive layer reaches many feet in depth. Although the lime has been eluviated from the $\mathrm{A}$ and much of the B horizons, the soil is neutral or only slightly acid, since a constant supply of lime is brought to the surface by the grasses and deposited ther'e when they die (Kellogg 1936). With decreasing precipitation in western Kansas and eastern Colorado the vegetation becomes sparser, the soil becomes lighter in color, and the solum thinner. In these Dark Brown and Brown soils, roots are shallower but very abundant.

\section{Predrought Distribution of Roots in True Prairie}

In true prairie roots extend widely and deeply. Those of the grasses commonly penetrate 4 to 7 feet. Only a few are shallower. Forbs are also deeply rooted and the roots commonly spread 2 or more feet laterally on all sides of the base of the plant. A very few species of these prairie plants have underground parts confined to the surface 2 feet; many are 4 to 5 feet deep; but about 65 percent of the forbs have roots that reach depths quite below 5 feet, a penetration of 8 to 12 feet being common and a maximum depth of over 20 feet sometimes being attained (Weaver 1919, 1920). In fact, the semiarid atmospheric conditions promote high water loss, and extensive root development occurs in the deeply moist but well-aerated soil. It is in eastern Nebraska and Kansas that root penetration is greater than anywhere farther westward or eastward in North American grasslands. Westward it is less because of dry subsoil (Albertson 1937; Weaver 1915, 1917). With increasing soil moisture and less evaporation eastward, as in Illinois, the same species root more shallowly (Sperry 1935).

\section{WATER INFILTRATion}

Root penetration during drought has been directly correlated with depth of moist soil. The grasses and forbs died in 1934-1936 only after they had exhausted the available water in the surface few feet of soil. The light showers of drought years or even scattered heavy rains were inadequate to moisten again the third, fourth, and fifth foot or at least all parts of this dry layer. Consequently, plants with roots not already established in the deep, moist subsoil were barred from entering it (in many areas) by 2 or more feet of permanently dry soil. Dependence upon current precipitation became much greater. But with the profound disturbance of the plant cover and its disappearance in places, the rate of entry of water into the soil was greatly decreased. This decrease in rate of infiltration profoundly affected root distribution.

Before presenting experimental evidence, the general statements may be made that bared soil greatly retarded water infiltration, that any type of cover living or dead promoted it, and that soil under the native prairie grasses absorbed water much more rapidly than soil covered with the great invader, western wheat grass.

Preliminary experiments were made in a prairie at Lincoln where the bunches of grass were about 12 inches apart but where the low-growing, interstitial species, including bluegrass, had been killed by drought. The soil was a very fine sandy loam, lightly covered with debris, and at the time of the experiments in midsummer it was dry. Water was sprinkled upon the dry vegetation and soil uniformly over an area of about 2.5 by 8 feet for a period of 30 minutes. The amount used was approximately equivalent to 1.6 inches of rainfall. Some water was intercepted by the foliage and evaporated without reaching the soil. A small amount was lost by runoff. Immediately after sprinkling a shallow trench was dug throughout the length of the area of wet soil and depth of water penetration was measured. The transition between the wet black soil and the lightercolored dry earth was distinct. The soil between the bunches was well occupied by laterally spreading roots of the grasses, at least below a depth of 2 inches.

The dense bunches of little bluestem lessened the depth of infiltration directly beneath them often to only half of the usual 6 inches which occurred between the bunches. There was an exception in one instance where the center of the bunch was dead and decayed. Infiltration under the bunches of prairie dropseed was not as great as between them where the soil was well mulched with dead leaves. But where bare soil occurred between bunches of needle grass, infiltration was much less than that beneath the clumps; otherwise there was little retardation of infiltration by the moderately sized, relatively recently established bunches. Maximum depth of water infiltration anywhere did not exceed 9 inches.

Similar experiments were performed in another prairie where large patches of bare soil alternated with grass-covered land. The dimensions of the watered area were about 6 by 2 feet. Here the granular layer of silt-loam soil was 12 inches deep and very dry. The drought-bared areas had all lost some soil, as is usual, by wind and water erosion, and were in consequence depressed about an inch below the general soil level. When 1.4 inches of water were added in 30 minutes to a dense stand of 
blue grama and bare soil, depth of penetration averaged 9 and 2 inches, respectively, and maximum depth in the same order 12.5 and 3.25 inches. Here, as before, depth of infiltration was determined immediately (Fig. 46).

In a second experiment, 2.8 inches of water were sprinkled upon another lot of blue grama and bare soil over a period of 1 hour. Average depth of moist soil immediately after sprinkling was 20.5 inches under the grass but only $\mathbf{1 1 . 5}$ in bare ground. A crack occurred at a few inches depth in the bare soil which permitted water penetration to 22 inches; numerous eracks at 12 inches beneath the sod allowed water to penetrate to 24 inches. Grass roots extended laterally 7 inches into the bare area (Fig. 46).

A third experiment was similar to the first in amount and time of application of water, but the grass was big bluestem. The bare soil without debris was depressed an inch below the general level. Also, as before, a thin sheet of water constantly covered this soil during the sprinkling. The results are shown

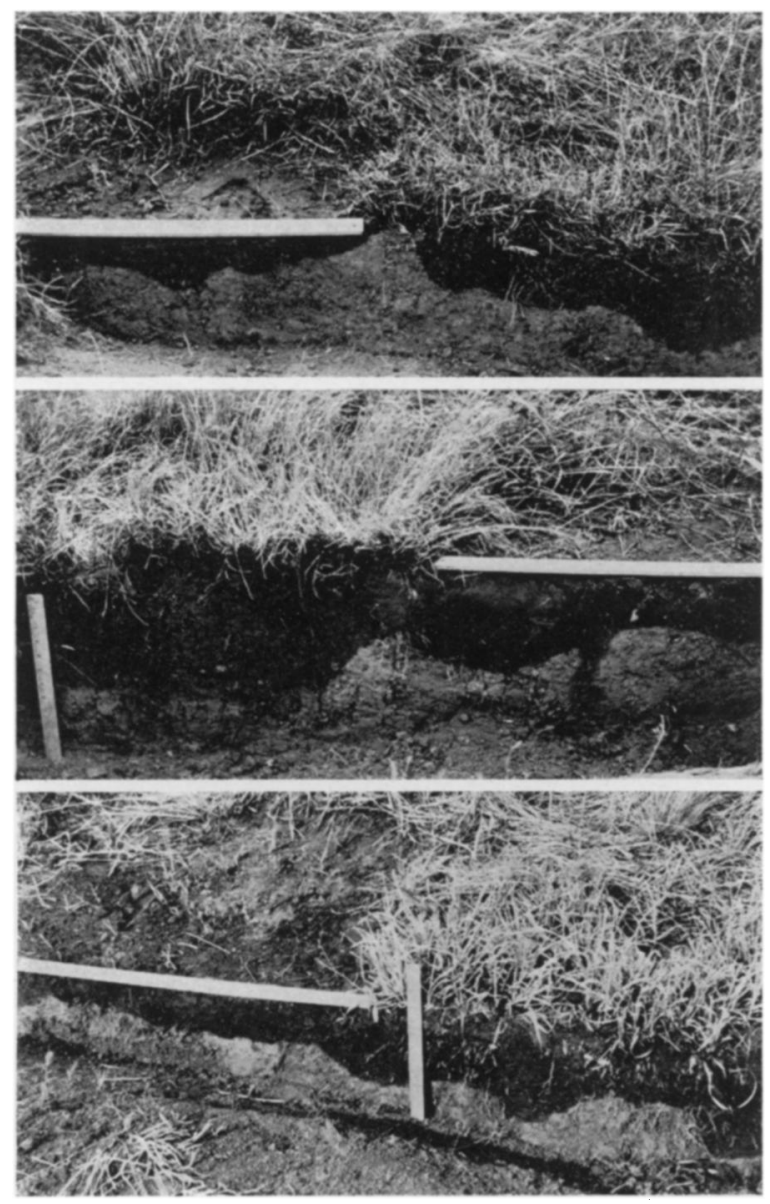

FIG. 46. Depth of water penetration in dry soil: (upper) where 1.4 inches of water were sprinkled on blue grama and bare soil in 30 minutes; (middle) where 2.8 inches were sprinkled on blue grama and bare soil in 60 minutes; and (lower) where 1.4 inches were sprinkled on big bluestem and bare soil in 30 minutes. in figure 46. Water infiltration under the 2.5-foot length of bare soil occurred to an average depth of 3 inches only. The minimum depth was 1.5 inches and the maximum 3.5. But under the bluestem sod, an average depth of 7 inches was found; minimum infiltration was 6 inches and maximum 9.5.

These experiments are representative of many others which gave similar results, infiltration into bare soil being least and through big bluestem sod greatest. Under western wheat grass, rate of infiltration was intermediate, averaging 5.5 inches compared with 7 inches under blue grama and 9 inches under big bluestem.

The rate of entry of water was measured for bared soil, for soil covered with bluestem or other predrought native grasses, and for the same soil clothed with western wheat grass. In these experiments steel cylinders one square foot in cross-sectional area and 4 inches long were used. The cylindrical wall was only $2 \mathrm{~mm}$. thick, and the steel was sharpened; hence, when it was oiled it could easily be forced vertically into the soil to a depth of 3.75 inches. Water was then added, as rapidly as it could be absorbed, from a sprinkling can with small perforations until an amount equalling 1.6 inches of rainfall had been applied. The time for the infiltration of the water was recorded. Data were obtained from eight widely separated prairies; six were in southeastern Nebraska and two in north-central Kansas. All were on soils of silt-loam texture but variable, of course, in proportions of sand, silt, and clay. The pairs of experimental areas were never more than 9 feet apart and sometimes only 6 feet. The results are shown in table 10.

TABLE 10. Minutes required for the infiltration of an inch of water sprinkled on one square foot of soil which was either bare or clothed with western wheat grass or with other prairie grasses.

\begin{tabular}{|c|c|c|c|c|c|c|}
\hline Station & 离: & 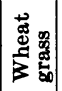 & 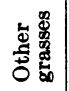 & Station & 空: & 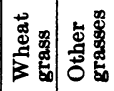 \\
\hline $\begin{array}{c}\text { Lincoln. } \\
"\end{array}$ & $\left|\begin{array}{l}33.0 \\
27.5\end{array}\right|$ & $\left|\begin{array}{l}30.0 \\
27.5\end{array}\right|$ & $\begin{array}{l}6.5^{1} \\
6.5^{1}\end{array} \mid$ & $\begin{array}{c}\text { Hebron . } \\
" \quad .\end{array}$ & & \begin{tabular}{|r|r|r|}
9.0 & $6.0^{1}$ \\
11.0 & $8.0^{2}$
\end{tabular} \\
\hline Pleasant Dale & 16.0 & 13.5 & $7.5^{1}$ & Nelson... & 17.5 & $18.0 \mid 5.0^{3}$ \\
\hline & $10.0 \mid$ & 6.5 & $4.0^{1}$ & Montrose. . & 21.0 & $12.55 .0^{1}$ \\
\hline$"$ & 17.0 & & $8.5^{2}$ & Belleville. & 11.5 & $11.58 .5^{1}$ \\
\hline$" \quad "$ & $20.0 \mid$ & & $3.0^{1} \mid$ & Clay Center. & 13.5 & 7.5 3.01 \\
\hline $\begin{array}{r}\text { Carleton... } \\
\quad " \ldots\end{array}$ & & $\left|\begin{array}{l}21.0 \\
17.0\end{array}\right|$ & $\begin{array}{r}8.0^{1} \\
11.0^{1}\end{array}$ & $" \quad "$ & 11.5 & $10.55^{5.5^{4}}$ \\
\hline$"$ & 19.5 & $\ldots$. & $9.5^{2} \mid$ & Average, all trials & 18.2 & 15.06 .6 \\
\hline
\end{tabular}

${ }^{1}$ Big bluestem. ${ }^{2}$ Blue grama. ${ }^{3}$ Side-oats grama. ${ }^{4}$ Penngylvania sedge.

If the average time for infiltration under the predrought grasses is considered as 1 , those under wheat grass and into bare soil are 2.3 and 2.8, respectively.

The rate at which the dry prairie soil absorbed water when populated with an average cover of bluestem grasses and the heavy rainfall required to wet the soil to the depth of little bluestem roots were ascertained by experiment. A prairie at Lincoln on a gentle lower slope on Lancaster silt-loam soil was used. Five-inch boards, five-eighths inch thick, were placed on edge on the sides and ends of a plot 5 
feet long and 3 feet wide. This was done by digging a trench four inches deep around the plot and staking the boards tightly against the sides and ends of the block of soil. Soil was then tamped firmly in the trench back of the boards. Water was added from several sprinkling cans simultaneously over the area but only as rapidly as it could be absorbed. In this manner a volume of water equivalent to 11 inches of rain was applied and absorbed in 4 hours. Two days were allowed for the water to reach an equilibrium in the soil after which a deep trench was dug across the lower third of the area and the depth of water penetration mapped as shown in Figure 47.

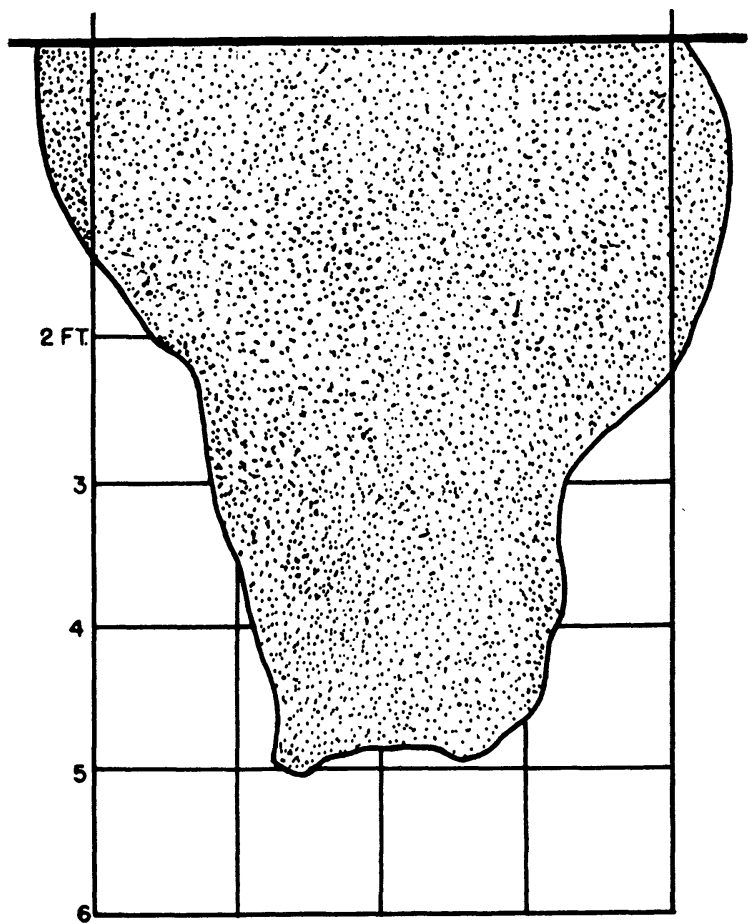

Fig. 47. Diagram showing depth of penetration of 11 inches of rainfall into dry soil covered with bluestem grasses. The water was applied by sprinkling and without runoff in 4 hours and the soil was examined two days later.

The 11 inches of water moistened the soil to field capacity to a depth of about 4 feet. Penetration was fairly uniform and there was no wide lateral spread of water as occurred in similar experiments in cultivated soils at the depth of the furrow-slice.

In a similar experiment in the same area with bluestems and western wheat grass, respectively, the first plot absorbed an equivalent of 7.27 inches of rainfall in 1.5 hours and the soil became wet to a depth of 29 inches. Soil covered with western wheat grass absorbed only 2.98 inches of water which moistened the soil to an average depth of 10.4 inches (Weaver 1942).

A survey of depth of moist soil from eastern Nebraska, through northern Kansas into eastern Colorado was made in June after the wet spring of 1941. It was found repeatedly that moisture penetrated more deeply in the prairies and ranges where a good cover of vegetation remained than it did 2 to 5 feet distant where the soil was bare (Table 11).

TABLE 11. Depth in inches of penetration of rainfall into bare soil and into soil covered with native grasses, mostly short grasses.

\begin{tabular}{c|c|c||c|c|c}
\hline \hline Station & $\begin{array}{c}\text { Bare } \\
\text { soil }\end{array}$ & Sod & Station & $\begin{array}{c}\text { Bare } \\
\text { soil }\end{array}$ & Sod \\
\hline Lincoln, Neb. . . . & $22-23$ & $32-38$ & Brewster, K:n... & $16-20$ & $40-43$ \\
Holdrege, Neb. ... & $11-12$ & $18-24$ & Goodland, Kan. . & $16-18$ & $18-24$ \\
Alma, Neb. ....... & $18-22$ & $19-24$ & Kanarado, Kan. .. & $18-21$ & $27-48$ \\
\hline
\end{tabular}

Differences in depth of soil moisture penetration at Lincoln, after a rain of 1.1 inches in August when the soil was very dry, were ascertained by a series of 16 measurements in the prairie. Moisture in bare places averages 3.7 inches deep, that under western wheat grass 4.0 inches, and that under bluestems 6.8 inches. These differences are representative of $\mathrm{nu}$ merous other measurements made throughout the drought years.

Robertson (1939) worked in these same prairies after 3 years of drought and compared rate of water penetration. He used steel cylinders 4 inches in diameter which were pressed into the soil 14 inches deep. Four inches of water were added to each cylinder, an inch at a time. Big bluestem soil absorbed most readily, soil occupied by wheat grass very much less rapidly, and bared soil least rapidly of all.

The reason for these differences seems clear. On soil without a cover of vegetation or debris, the impact of raindrops or of water sprinkled on the surface loosens the soil particles which are then suspended in the water. This water in entering the soil pores carries the fine, suspended particles with it. The pores are more or less completely clogged on the surface and a compacted layer of soil formed (Lowdermilk 1930). This layer greatly decreases absorption and increases water loss by runoff. Western wheat grass has invaded many areas upon which wind-blown dust has been deposited and through which water infiltrated only slowly. But even where the soil was not dust-covered, this grass has furnished little debris during the drought years and much bare ground is exposed. On soil with a complete cover of true prairie grasses, runoff water is clear (Weaver and Noll 1935). The effects of living and dead roots of different grasses upon the movement of water through the soil, once it has gained entrance, await study. A closely connected problem is their effect upon soil granulation and consequent infiltration rate (Pavlychenko 1941).

Recent studies by Duley (1939) and Duley and Kelly (1939) with mulches on cultivated soil have shown that this clogging of the soil pores and "the development of a condensed layer on the surface of cultivated bare soil has far greater effect on the intake of water than differences in soil type, degree of slope, previous moisture content of the soil, or the rate of rainfall. In fact, . . . it seemed to have a 
greater effect than all these other factors combined." Soils covered with a crop had a much higher rate of infiltration of water than bare soils and the more dense crops like native sod and alfalfa had the highest infiltration rates, and these rates were maintained throughout the longest period. Thus, conditions on the soil surface greatly influence water content of soil, and this in turn is a controlling factor in distribution of roots of the grasses and forbs.

\section{Underground Plant Parts in True Prairie}

A resurvey of underground plant parts involved examination of prairies of several different types. It included (1) relic grassland where the original plant population was little affected, at least above ground; (2) a study of badly denuded areas where only widely scattered relic or invading grasses occurred; and (3) an examination of half-bared places where relic grasses or invading species occupied the land.

Near the end of the drought, grasses and forbs were examined on both east and west hillsides at Valparaiso, Nebraska, where large local patches of vegetation, each several square rods in area, had escaped with little damage. A large cut, many feet deep, made through the hill in road construction revealed no differences in soil in the places below or above these patches where vegetation had been badly damaged. Nor were differences found in soil characteristics, except in water content, in the deep trenches prepared for root excavation. Under the intact sod, moist soil, except in the surface, was continuous to greater depths than the roots penetrated. Andropogon furcatus had normal predrought development throughout a root depth of 7 to 8 feet. Sporobolus asper had an abundance of well-branched, strong fibrous roots to 6 feet in depth and some penetrated the moist soil to 7 feet. Stipa spartea was even more deeply rooted than previously found (Weaver 1919, 1920). Depths of 5 to 6.5 feet were common and roots of some plants extended downward nearly 8 feet. The prominent taproots of Psoralea floribunda were traced to their usual predrought depth of 7 to 9 feet. Three plants of Liatris punctata were examined. They showed normal predrought conditions in every respect and no modification was found in the root system that could be attributed to drought. They penetrated to a depth of 9 to 10 feet. A plant of Kuhnia glutinosa with 31 stems and a height of 16 inches had a taproot 2 inches thick. It was traced to a depth of 11 feet where it and some of its major branches, which were still $2 \mathrm{~mm}$. in diameter, followed a downward course in the moist soil. This root system was normal as compared with those of similar plants examined several years earlier when rainfall was near the mean.

These results are representative of those obtained elsewhere and illustrate the fact that in many areas of relic vegetation, little or no death resulted underground. This is further confirmed by the lack of an abundance of dead roots, which were commonly found elsewhere, and the persistence of Andropogon scoparius, a dominant grass which resisted drought least.

From a typical prairie near Pleasant Dale, Nebraska, representative of numerous others of the more open type, samples of soil for study of root content were taken in midsummer near the end of the drought. They were obtained to a depth of 4 inches only and between the scattered bunches or sods of grass in such a manner that no soil was obtained except at a distance of at least 5 inches from the base of any perennial grass. The samples varied from 9 by 12 inches to 16 by 36 inches in surface area. The interstitial vegetation, if any, consisted of seedling grasses, young plants of Aster multiflorus, or an occasional plant of Salsola pestifer. The chief grasses were big bluestem, needle grass, tall dropseed, prairie dropseed, and blue grama. Fifteen samples, representing an area of 21 square feet, were thus removed and the living roots separated from the soil, dried and weighed. So sparsely was the soil occupied that the total weight of roots was only 64 grams. This is approximately only 4 percent of the dry weight of the original root mass (Weaver and Harmon 1935).

Trenches dug in this prairie revealed a granular layer of soil only 8 inches deep overlying the pronounced prismatic $B$ horizon which was dry and hard and the prisms much shrunken, exposing great vertical cracks and fissures. Some of the larger cracks extended to the soil surface and thus permitted rapid loss of soil moisture to depths of several feet (Fig. 48). In this dry soil, the widely

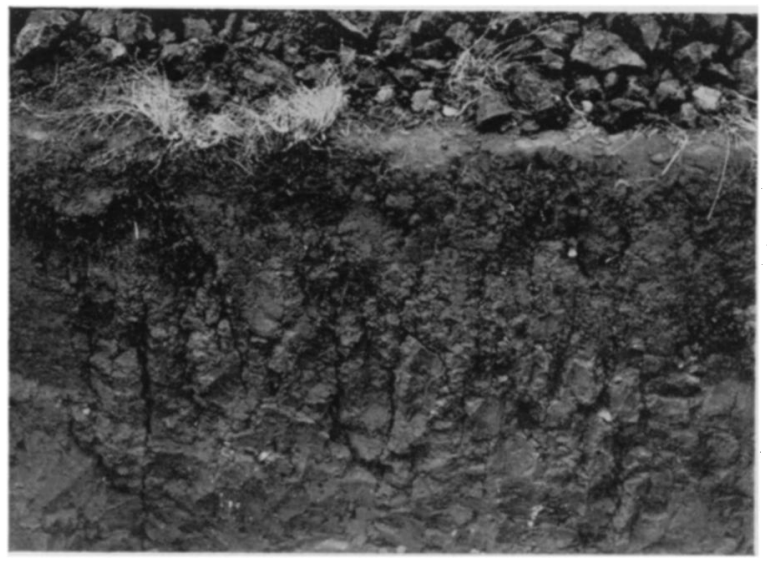

FIG. 48. Wall of trench where root systems were examined showing dried and cracked soil to a depth of about 4 feet. Pleasant Dale, Neb., July, 1940.

spaced relic bunches of Stipa spartea, Andropogon furcatus, Sporobolus asper, and mats of Bouteloua gracilis were examined. Roots were distributed somewhat irregularly on the faces of the prisms, and especially in the deeper crevices where water penetration was not uniform. Roots of needle grass were abundant to 2.3 feet; very few extended deeper. Those of blue grama were abundant to a similar depth, as were those of the other species. Lateral spread of roots was more pronounced in every in- 
stance than where these grasses grew in competition with closely adjacent plants. Dead roots were abundant everywhere and especially noticeable in dry soil below the penetration of the living ones. They occupied layers of soil which had not been moistened since the early years of the drought. Repeated soil samplings and root studies elsewhere showed that the conditions of underground plant parts here described recurred again and again over widely separated areas.

Studies in vegetation where relic big bluestem had spread to reclaim drought-damaged territory and occurred in contact with pure stands of western wheat grass were conducted in several prairies. These were made near the end of the drought. The first was on a west slope in the prairie used for experimental purposes near Lincoln. Western wheat grass was 2 feet tall and had headed normally; big bluestem at the opposite end of the trench was 14 inches high. Soil under western wheat grass contained large quantities of dead roots of other grasses, especially bluestems, the chief previous occupants. Roots of the invader followed the old channels of the former bluestems to a remarkable degree. They were often encased for a distance of several inches by the reddish brown cortex of these dead roots. Penetration was only to the dry soil at a depth of 2 feet. Roots were exceptionally well branched and laterals were unusually long. The grass had absorbed the water in the surface 2 feet, where the soil was now (May 31) very dry. Big bluestem had living roots to the depth of moist soil, about 33 inches. At greater depths only dead roots were found. The strong, deep taproots of Psoralea floribunda and Kuhnia glutinosa, which had survived the drought, extended through several feet of dry soil, in which water content was so low that grasses could not grow, to the deeper soil below 5 feet which had been moist since the beginning of drought.

Another trench was dug on May 30, at right angles to the slope on a north hillside. Formerly the whole hillside was occupied by prairie grasses common to the little bluestem type which included a large percentage of big bluestem. Drought had killed nearly all of the little bluestem, whose place had been taken by big bluestem, Carex pennsylvanica, and Aster multiflorus. There was a good cover of vegetation. Wind had drifted in dust to a depth of 2 to 4 inches from an adjacent field and smothered the grasses on a part of the slope. This territory was then invaded by western wheat grass in 1936-1938. By 1940 it formed a good stand. No other perennial grasses or forbs occurred where western wheat grass grew.

One end of the 7.5-foot trench was in pure wheat grass; the other end was in prairie undisturbed except by the loss of little bluestem. The transition zone near the middle of the trench, where western wheat grass and bluestem intermingled, was 18 inches wide. The average depth of root penetration under western wheat grass was only 29 inches. The maximum depth was 31 inches, except near the transition zone where the soil was moist to 37 inches. At greater depths the soil was dry and no living roots were found. An abundance of dead roots of the bluestems and other prairie plants including Equisetum laevigatum, Echinacea pallida, and Astragalus crassicarpus revealed clearly the former presence of a different population. Many of these dead roots extended to 56 inches and some were 68 inches deep. Despite the shallow depth of soil moisture, western wheat grass was in excellent condition. The foliage was 20 inches high and the flower stalks 33 inches tall. The plants had headed in a normal manner. The very dry midsummer of 1940 had greatly retarded the growth of prairie grasses and as a consequence wheat grass had invaded big bluestem, forming the present transition area.

At the opposite end of the trench, big bluestem was 10 inches tall and growing vigorously. In this moist soil, the prairie grasses and many-flowered aster reached depths of 43 to 61 inches, depending upon the depth of soil moisture. Here the soil had not only been moistened much deeper but also an available water content of about 8 percent was still present (Fig. 49).

A deep trench, 16 feet long, was dug on a level hilltop 9 miles west of Lincoln, in an area illustrative of the usual depth of moist soil and roots during the late years of the drought. This was done late in July. The granular soil of the A horizon reached a depth of 1.5 feet, the prismatic structure in the B horizon extended to nearly 4 feet, below which occurred the massive soil of the $\mathrm{C}$ horizon. Drought was severe, the granular soil was dry, cracks occurred in the B horizon much as shown in Figure 48, and the C horizon was without water available to growth to a depth of 5.5 feet. At a depth beyond that of greatest root penetration of the grasses, the deep subsoil (parent material) was moist.

Wheat grass, which had dried and lost its green color without heading, had, a few years earlier, invaded half of the area trenched. Except for a few deeply rooted, long-lived forbs, it occurred in a dense pure stand. The few plants of Kuhnia glutinosa and Psoralea floribunda that remained alive were much dwarfed but unwilted. A nearly pure growth of big bluestem formed a sod just beyond. This grass was still green but partly wilted. With it occurred dwarfed specimens of Amorpha canescens and Liatris punctata.

Roots of western wheat grass occurred in great abundance but to a depth of only 2 feet. They were branched to very near the tip, as is characteristic of this normally deeply rooted grass (5 to 8 feet) when growing in shallow dry soil. The roots of big bluestem, owing to greater water penetration, thoroughly occupied the soil to a depth of 2.5 feet. Forbs were much deeper. Relationships of roots to tops and to moist soil are shown in Figure 50.

Despite the great depth of rooting of most forbs, season after season with intensive atmospheric drought and severe competition for water (especially with wheat grass) in the surface soil had resulted in their wilting and dwarfing and finally in the death 


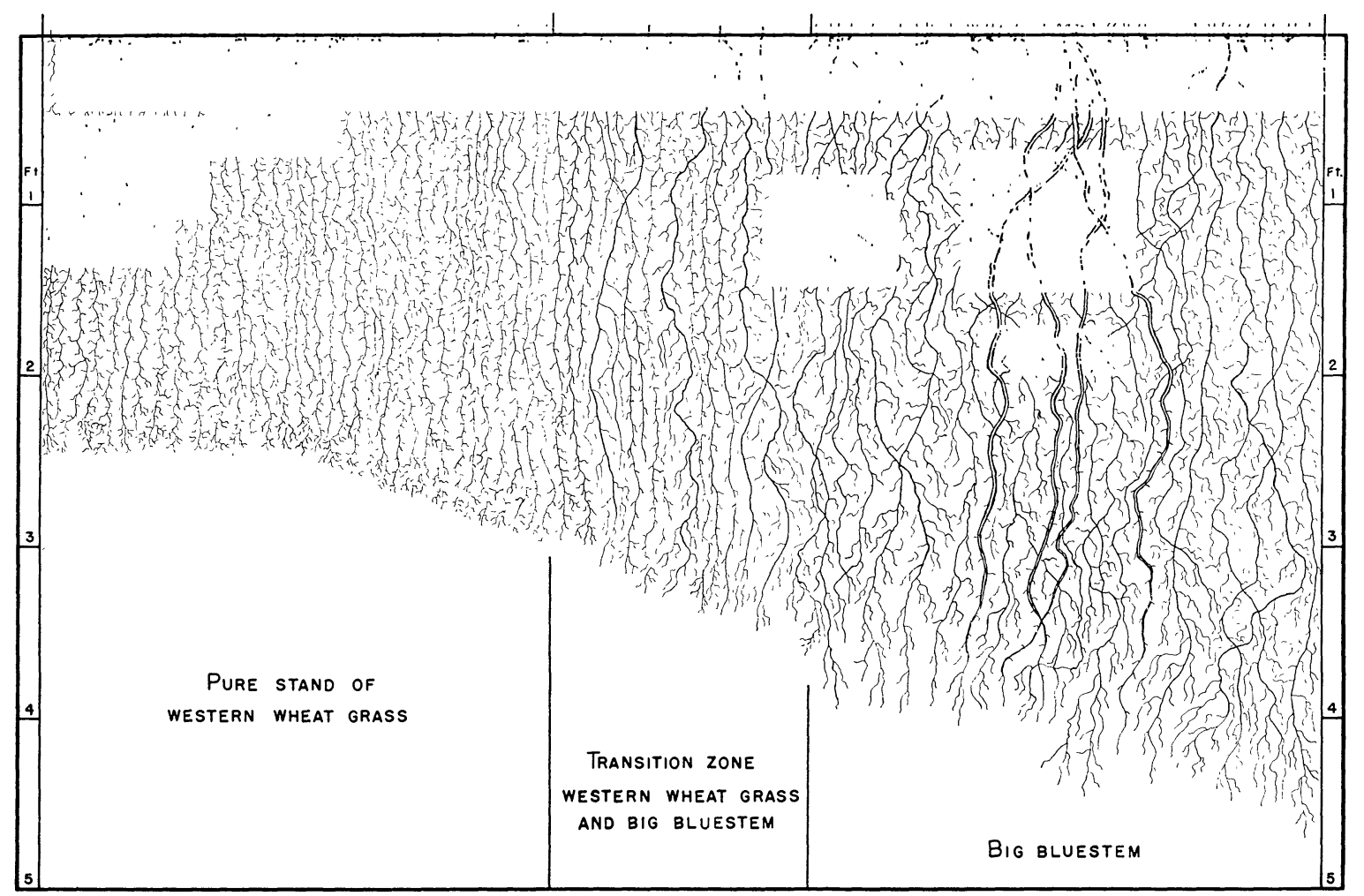

FIG. 49. Diagram showing root depth of western wheat grass above a layer of dry soil, and deeper penetration of roots of big bluestem and many-flowered aster where water penetration was greater and the soil was moist.

of very large numbers. That roots of little bluestem, big bluestem, and other grasses were formerly abundant to 4 to 7 feet was shown by their dead remains, still only partially decayed, in the deeper soil.

It is an important fact that native pastures which were only moderately grazed withstood the drought better than ungrazed prairie (Weaver and Albertson 1936). This resulted from the great decrease in amounts of water absorbed and transpired during the period of intensive atmospheric as well as edaphic drought. Conversely, pastures long overgrazed and hence in the bluegrass stage quickly yielded to drought. Here as in other depleted grasslands, a moist subsoil at 3.5 or 4 feet was common, despite dry soil at this depth in adjacent native prairie. This deeper water was not absorbed because of the relatively shallower roots of bluegrass or weakened little bluestem and other species found in low-grade pastures. The invasion of western wheat grass into the drought-stricken pastures and its early use of available water have greatly retarded the growth of better forage grasses. Sand dropseed, which invaded thousands of denuded pastures over a very wide area immediately following the drought (Weaver and Hansen 1939), has likewise delayed the normal succession by its annual absorption of most of the available water (Weaver and Hansen 1941a).

Rain in the spring of 1941 moistened the soil more deeply and enabled western wheat grass to penetrate to 3.5 to 4 feet in the area shown in Figure 50 . Big bluestem extended downward even farther into the newly moistened soil which in July, 1941, was separated from the moist soil below by a layer of dry soil only 6 to 12 inches thick. This occurred despite the comparatively dry midsummer. At this writing (May, 1942) soil moisture in the upper layer is now in contact with that in the deep subsoil and the roots of both seedling grasses and young forbs are growing deeply in the cool moist soil. This condition is quite general. With return of normal rainfall and the consequent increase in seed production, seedling establishment, and vigorous vegetative development, an excellent stand of prairie grasses and forbs will again cover and protect the soil.

\section{Underground Plant Parts in Mixed Prairie}

Distribution and interrelations of root systems in the short-grass disclimax and the big bluestem consocies were studied and described in 1930-1932 (Albertson 1937). Extensive studies in the shortgrass faciation in Colorado had been made even earlier (Shantz 1911; Weaver 1919, 1920). Numerous observations during the drought indicated that both root depth and distribution as well as amount of underground plant parts had been greatly modified. These changes were variable, depending upon the depth of water penetration, number and length of periods without available water in the soil, and often upon the extent to which the grassland had been subjected to grazing. On ranges where deferred grazing was practiced and where the location was such that little dust blew in from adjacent fields, a fairly 


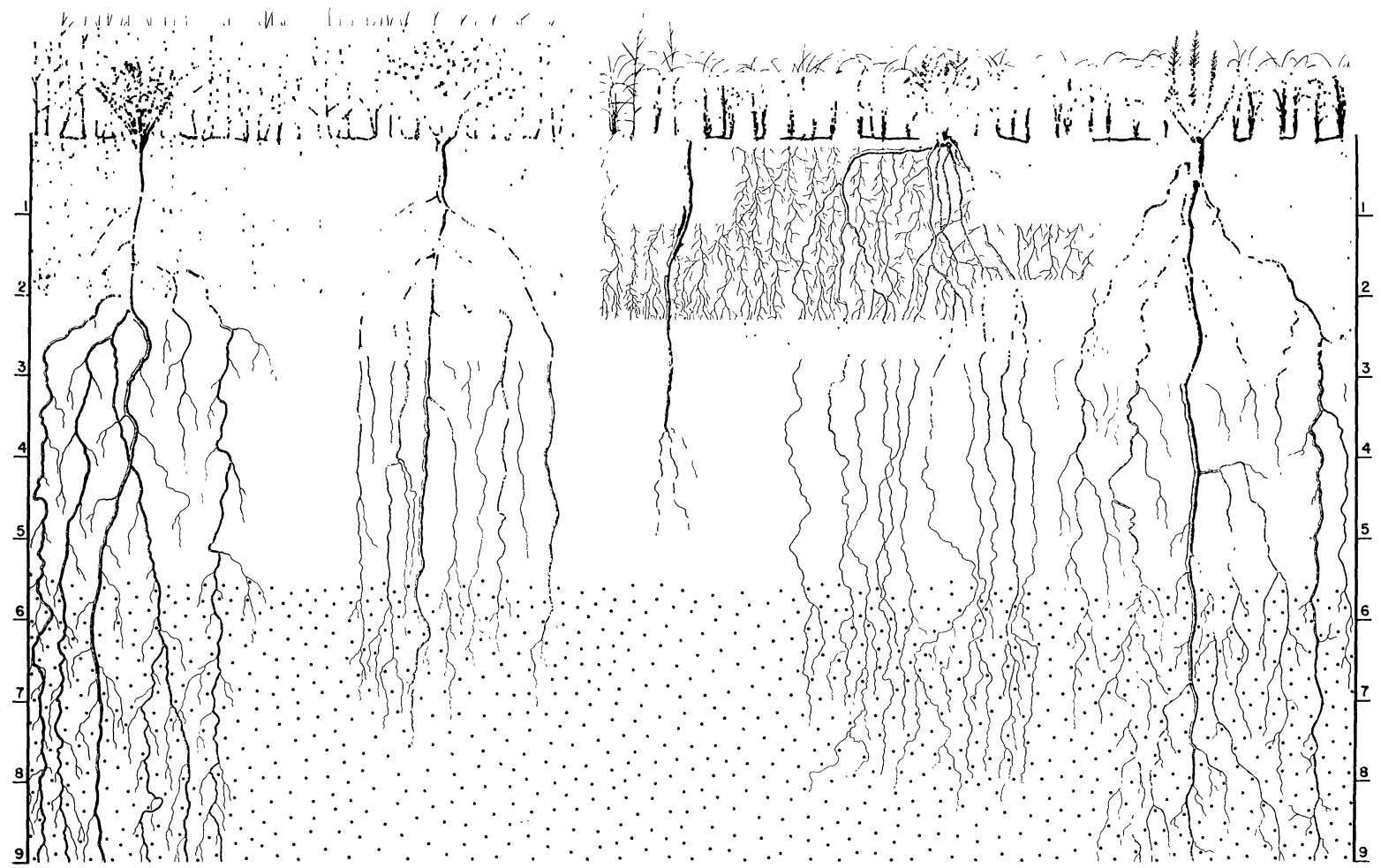

FIG. 50. Relation of roots of Agropyron smithii (left half of trench wall) and Andropogon furcatus (right half) and of forbs to moist and dry soil in deep silt-loam soil near the end of the drought. The dry layer between 2-2.5 and 5.5 feet is the result of complete exhaustion of available water by the original plant cover before its death in 1934-1936. The grass roots penetrated only to the depth of currently moist soil. The relic forbs-Kuhnia glutinosa (left) and Liatris punctata (right) - have survived because their roots are in moderately moist soil between 5.5 and about 16 feet depth. Psoralea floribunda (left center) and Amorpha canescens (right center), have also persisted because of deep soil moisture. Echinacea pallida (center) succumbed to desiccation.

continuous cover was sometimes maintained. But as drought progressed and grazing of the weakened plants was permitted and movement of dust became greater, large areas of range land were rendered completely devoid of vegetation. The dead roots decayed, there was no new growth, and the soil became intensely susceptible to erosion by wind and water.

\section{STUDIES IN THE SHORT-GRASS TYPE}

Preceding the dry years, the two dominant short grasses, blue grama and buffalo grass, occupied the soil with a dense mass of roots to about 4 feet in depth, large numbers of the much-branched threadlike roots extending to 5 feet (Fig. 51). The sod was extremely dense, tough, and resistant to erosion. When cut a few inches deep into strips 12 to 18 inches wide, it could be rolled in the manner of bluegrass sod and, like it, used in renewing or establishing a cover of grass elsewhere.

Among the forbs seattered throughout, the roots of Psoralea tenuiflora, Malvastrum coccineum, and Kuhnia glutinosa penetrated 9 to 12 feet in depth. Consequently, they obtained much of their water supply from the subsoil beyond the extent of the roots of the short grasses. Roots of many other common species of forbs did not penetrate beyond a depth of 5 feet and thus absorbed from the same soil levels as the grasses. The following are representative: Ambrosia psilostachya, Lygodesmia juncea, Sideranthus spinulosus, and Allionia linearis.

\section{CHANGES DURING DROUGHT}

With continued drought, marked changes in rooting habits occurred. The roots of the two dominant short grasses were profoundly reduced in numbers and in depth of penetration. Below 2 feet, roots of these grasses were extremely scarce (Fig. 52). Investigations in widely scattered places on the depth of the penetration of roots on the hard lands in western Kansas and eastern Colorado showed that most of the roots of the two dominant grasses were limited to the upper foot of soil. Here precipitation was less than that at Hays. In many places the cover was so reduced that only small isolated tufts 1 to 2 inches in diameter remained. Spread of the surface roots was usually not more than 6 inches, and although occasionally a root penetrated to 18 inches, nearly all were in the surface foot.

Most of the fully grown forbs established before the drought had succumbed, and nearly all remaining in 1940 were either young plants when the drought began or plants that had become established during the most favorable periods during the drought. For example, the roots of Psoralea tenuiflora were nearly 


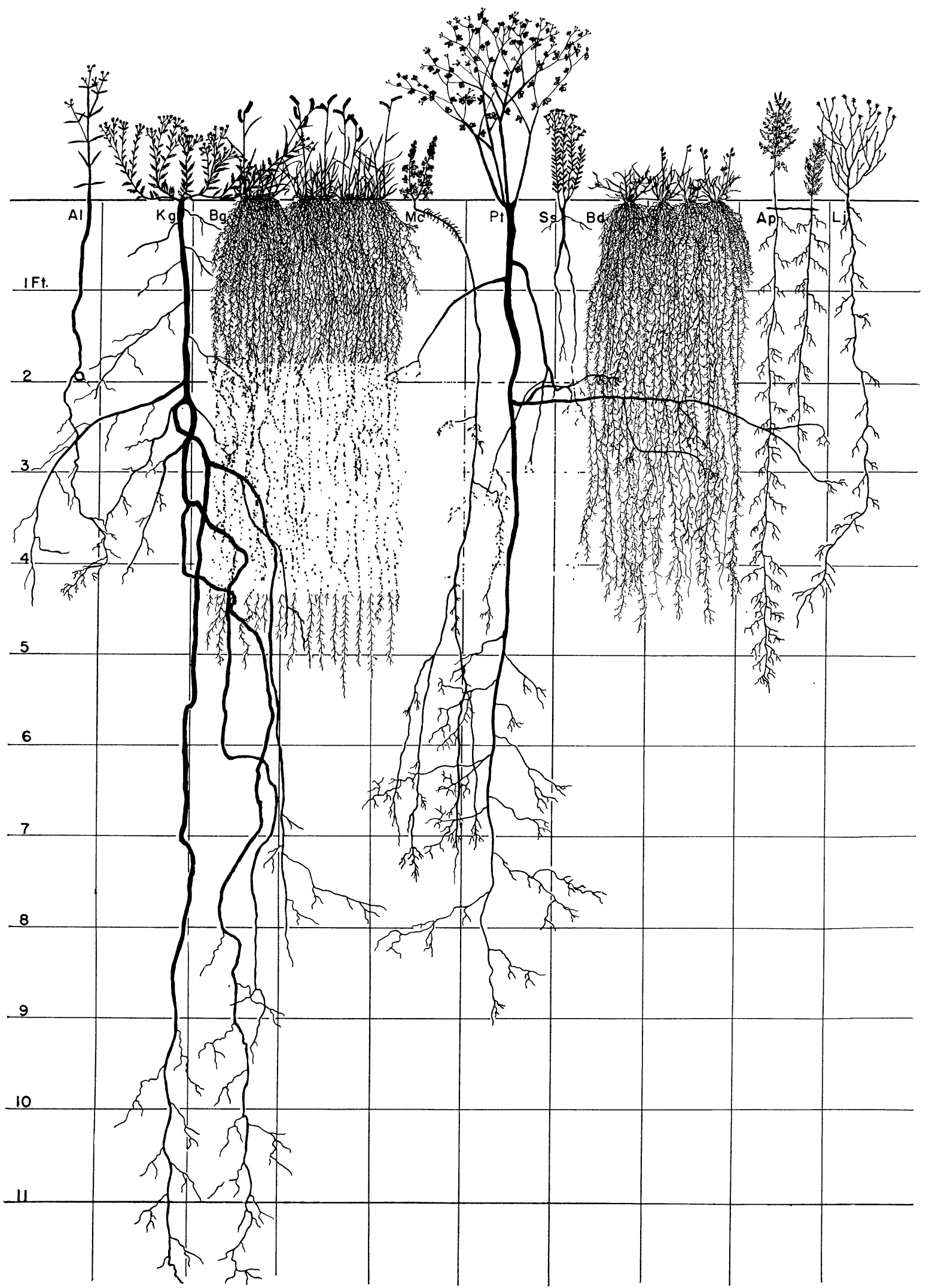

FIG. 51. Root development of native prairie plants in the short-grass type of the mixed prairie at Hays, Kan., before the great drought. Al, Allionia linearis; $\mathrm{Kg}$, Kuhnia glutinosa; Bg, Bouteloua gracilis; Me, Malvastrum coccineum; Pt, Psoralea tenuiflora; Ss, Sideranthus spinulosus; Bd, Buchloe dactyloides; Ap, Ambrosia psilostachya; and Lj, Lygodesmia juncea. 


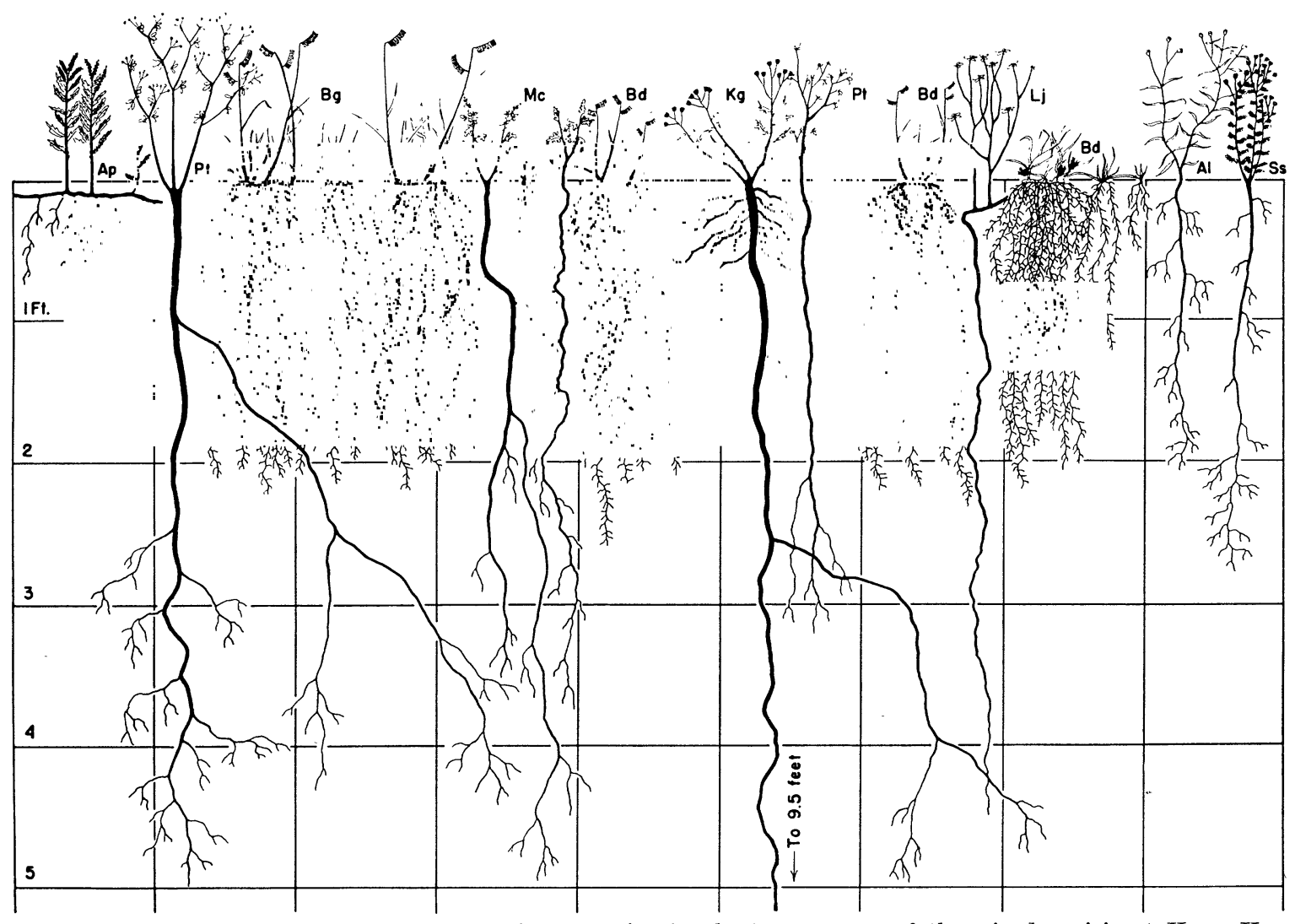

FIG. 52. Root development of native prairie plants in the short-grass type of the mixed prairie at Hays, Kan., at the end of the great drought. Ap, Ambrosia psilostachya; Pt, Psoralea tenuiflora; $\mathrm{Bg}$, Bouteloua gracilis; Me, Malvastrum coccineum; Bd, Buchloe dactyloides; $\mathrm{Kg}$, Kuhnia glutinosa; Lj, Lygodesmia juncea; Al, Allionia linearis; and Ss, Sideranthus spinulosus.

always much smaller in diameter than those excavated in 1932, and seldom penetrated beyond 4 feet, as compared with a previous depth of penetration of 7 to 9 feet. Malvastrum coccineum was one of the few species which increased in numbers, but did so with a greatly reduced root system (Figs. 51 and 52 ). Only occasionally was a root found to extend deeper than 4 feet. Plants of Kuhnia glutinosa in 1932 had roots to a depth of 12 feet in the short-grass sod. But after the drought they were mostly only about half this depth and none extended deeper than 9.5 feet. Little change in rooting habit occurred in forbs whose root systems were formerly limited to 4 feet of soil, although most of them suffered very heavy losses. During the years 1934 to 1939, inclusive, there was a dry layer of soil between 2 and 5 feet in depth underlying the short grasses, at least at the numerous stations where regular soil sampling was carried on. Below this there were small amounts of residual soil moisture available throughout the drought years. The species most successful in surviving the drought were either those with roots that had previously grown into this lower subsoil or those that evaded drought by limiting their activities to short periods (usually early spring) when conditions of growth were most favorable.

\section{QUANTITY OF UNDERGROUND PLANT PARTS}

The amount of living underground plant parts in the first 4 inches of soil under the short grasses was ascertained at Hays. Methods used were those described by Weaver and Harmon (1935) and Kramer and Weaver (1936). Samples were taken from adjacent areas where the environmental conditions were approximately similar. In one location the grasses had been protected from grazing since 1932, and had been only moderately grazed previously. The second sampling area had been moderately grazed for 40 years. The third one had been subjected to overgrazing until 1935 when it was further damaged by a covering of dust, and grazing was discontinued. A general view of the conditions of a badly overgrazed range is shown in Figure 53. Samples were taken from carefully selected places to represent average cover in each range-ungrazed, moderately grazed, and heavily grazed, respectively. Basal cover of the three samples was 46,37 , and 21 percent, respectively. These percentages are somewhat higher than the average cover of most western ranges in 1940. The percentage of total cover composed of blue grama grass and buffalo grass, together with volume and weight of the underground parts, is shown in Table 12.

The appearance of the sod before the tops of the 


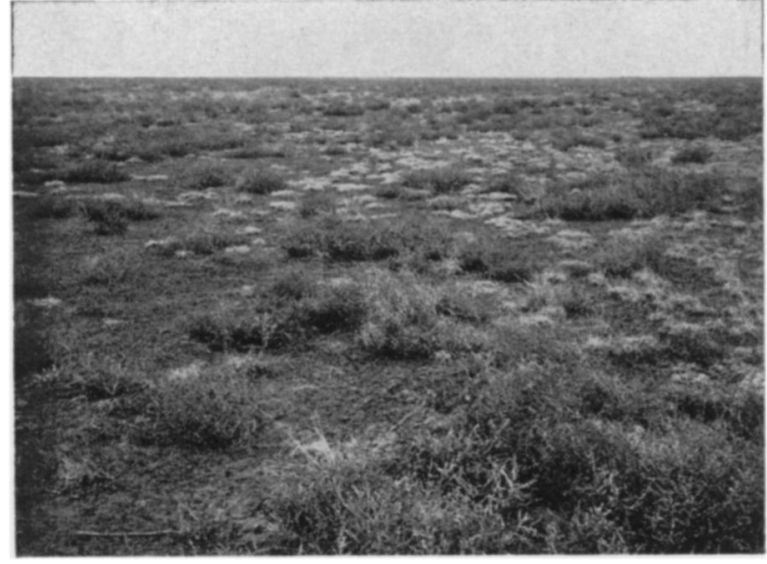

Fig. 53. General view of scattered bunches of buffalo grass and blue grama in western Kansas at the close of the drought. Light-colored bunches are the grasses; the large weeds are Russian thistles.

TABLE 12. Volume and air-dry weight of underground plant parts in the upper 4 inches of one-half square meter of short-grass sod subjected to different intensities of grazing at Hays, Kansas.

\begin{tabular}{|c|c|c|c|c|c|}
\hline \multirow{2}{*}{ Condition } & \multirow{2}{*}{$\begin{array}{l}\text { Percent } \\
\text { basal } \\
\text { cover }\end{array}$} & \multicolumn{2}{|c|}{$\begin{array}{l}\text { Composition of } \\
\text { cover in percent }\end{array}$} & \multicolumn{2}{|c|}{$\begin{array}{l}\text { Underground } \\
\text { plant parts }\end{array}$} \\
\hline & & $\begin{array}{c}\text { Blue } \\
\text { grama }\end{array}$ & $\underset{\text { grass }}{\text { Buffalo }}$ & $\begin{array}{l}\text { Volume } \\
\text { in cc. }\end{array}$ & $\begin{array}{c}\text { Dry } \\
\text { weight } \\
\text { in } \mathrm{gm} .\end{array}$ \\
\hline Ungrazed.......... & 45.8 & 26.0 & 74.0 & 1,232 & 276 \\
\hline Moderately grazed. & 36.6 & 43.0 & 57.0 & 1,114 & 244 \\
\hline Overgrazed. . & 21.1 & 55.0 & 45.0 & 582 & 121 \\
\hline
\end{tabular}

grasses were removed, and the underground parts alone are shown for the ungrazed and overgrazed pastures in Figures 54 and 55 . Table 12 shows a considerable decrease in both volume and weight from the ungrazed to the moderately grazed pasture. The decrease in volume (53 percent) and weight (56 percent) as a result of overgrazing is very great.

Number of roots per unit area, that extended to a

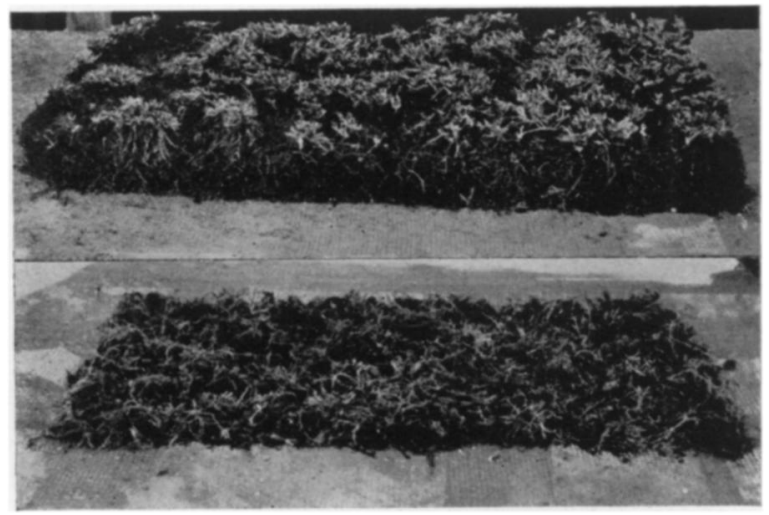

Fig. 54. (Above) Sod of short grass a meter long, one-half meter wide, and one decimeter deep, from an ungrazed range at Hays, Kan. (Below) Underground materials remaining when the soil was removed. depth of 4 inches, was counted for the three conditions of grazing. Representative one-half square meter samples were excavated to 4 inches depth and inverted. Enough soil was then removed by a gentle spray of water so that the roots protruded. Circles 3.5 inches in diameter were marked off on the sod and all of the roots within these sample areas were counted. They were very uniformly distributed in the protected sod and averaged 45 per circle. But in the overgrazed sod, portions of soil without roots protruding and comparable to the bare patches on the upper surface were common (Fig. 56). The average number of roots in this sample was only 10 per unit area. The overgrazed sod was easily broken and not well held together by underground parts. As shown by Kramer and Weaver (1936), resistance to erosion is, in general, proportional to the quantity of plant materials both above and below ground. Overgrazing and drought often result not only in the loss of the cover of grass but also of the top soil as well.

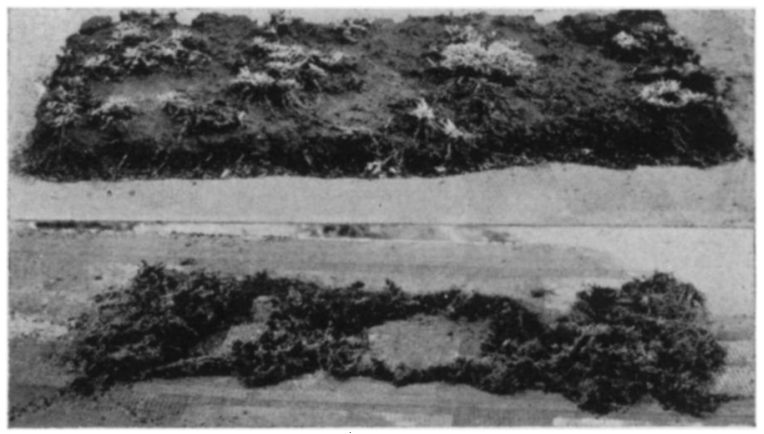

Fig. 55. (Above) Sod of short grass as in Fig. 54, but from an overgrazed range. (Below) Underground materials remaining after the soil had been washed away.

\section{STUDIES IN THE BIG BLUESTEM TYPE}

Roots of grasses and forbs commonly found in the postclimax big bluestem before 1933 have been described (Albertson 1937). Bisects were again made in 1940 to ascertain root depth and spread at the end of the drought (Fig. 57). During increase in desiccation the root systems of most species grew into deeper soil and a greater number of rootlets developed at the deeper level. The average root depths in feet of 8 important species before (1932) and near the close of the drought (1939) were as follows:

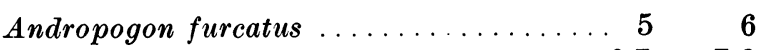

Agropyron smithii . . . . . . . . . . 6-7 $\quad$ 7-8

Bouteloua curtipendula . . . . . . . . . . 5 5 6

Psoralea tenuiflora ...............

Kuhnia glutinosa ............... $10 \quad 12$

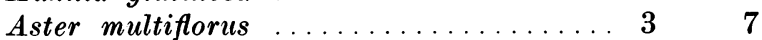

Vernonia baldwini ..............4 $4 \quad 8$

Salvia pitcheri ................4 4

Thus, the roots of all of these species (and others) not only penetrated deeper into the moist subsoil, following drought in the solum, but the roots of Aster, Vernonia, and Salvia doubled their former 

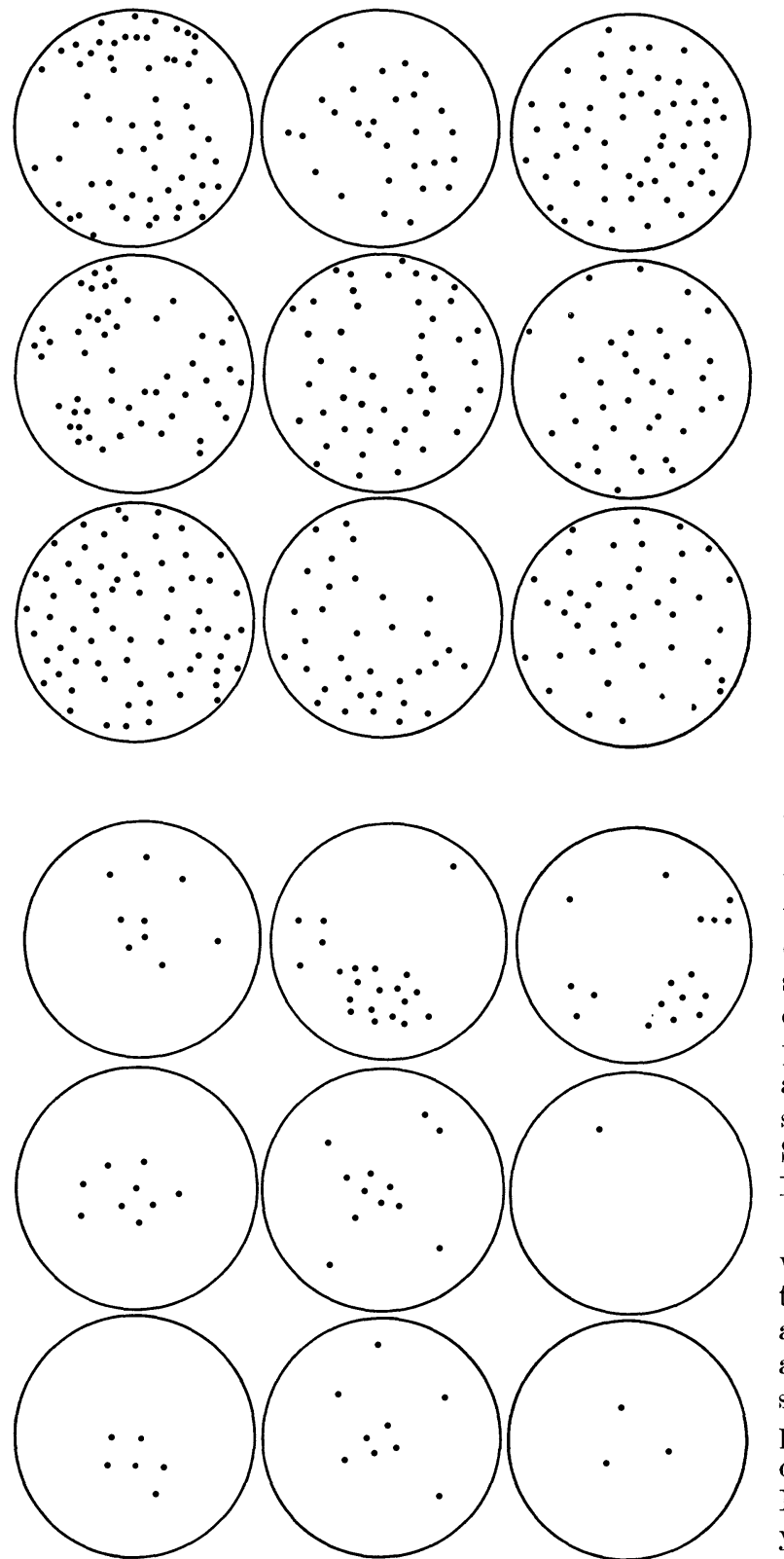

Fig. 56. (Above) Number of roots (dots) of ungrazed short grasses in representative circular areas 3.5 inches in diameter at a depth of 4 inches. (Below) Roots in similar representative areas of overgrazed grasses.

length. The roots of Panicum virgatum did not inerease beyond their former 7-foot depth, but they became much more numerous than formerly in the deeper soil. Thus, changes resulting from drought in upland and lowland species were quite diverse.

\section{PLANT YIELD IN RELATION TO WATER CONTENT OF SOIL}

The yield of grasses and forbs of prairie and the amount of available soil moisture were ascertained during the dry year of 1940 and the moderately wet one of 1941. This survey was a continuation of similar studies in 1939 (Weaver and Albertson 1940). Twelve separate prairies were studied. They ranged from western Iowa to western Kansas and represented four different types of vegetation. Those in western Iowa (Iowa group) were virgin bluestem prairies practically undisturbed by drought. The Lincoln group, including also Hebron, Nebraska, and Belleville, Kansas, were also bluestem prairies but they had been more or less damaged by drought. They maintained a fairly good cover. The third group was characterized by the almost complete loss of bluestems and their replacement by a dense stand of western wheat grass at Carleton, Clay Center, and Montrose (Fig. 1). The most westerly group is in the mixed prairie association but is now clothed only with the most drought-resisting short grasses. Soils are all similar, being of silt-loam texture; although those at Lincoln and eastward belong to the Prairie zonal group, while those under lighter precipitation westward are Chernozems. All are of high fertility, and water is the chief limiting factor to plant growth.

Stations for obtaining samples for water content were selected with reference to typical and relatively uniform composition of vegetation. There were included in each group of stations various gentle slopes and nearly level uplands, where water content of soil depended entirely upon precipitation. Samples were obtained regularly to a depth of 6 feet and at approximately the same time at each of the stations from the middle of April until early in September in 1940, and from May 1 to August 30 in 1941.

Five sample plots, each 4 square meters in area, were staked out in spring in the general vicinity of the soil-sampling areas. They were a few rods apart and selected at random. The vegetation was clipped at a height of 1.5 inches at each subsequent soil sampling, grasses and native forbs (and weeds if present) being harvested separately. These were airdried and the weight obtained to the nearest gram. From five similar plots in each prairie, total seasonal yield was also obtained at the last clipping. Monthly clippings were made only in 1940, but total seasonal yields were again obtained in 1941 from areas previously undisturbed except by annual mowing.

Basal cover at the several stations was far less than the normal predrought cover, except that of the Iowa prairies where drought had not been severe. The amount of decrease in cover has been determined many times by means of quadrats before, during, and at the end of the drought. At the NebraskaKansas bluestem stations it had been reduced to about 33 percent normal. At the stations where bluestems had died and western wheat grass had invaded, the cover was only 20 percent normal. Losses in the mixed prairie resulted in a very open cover, approximately 10 percent of that occurring before the drought. 


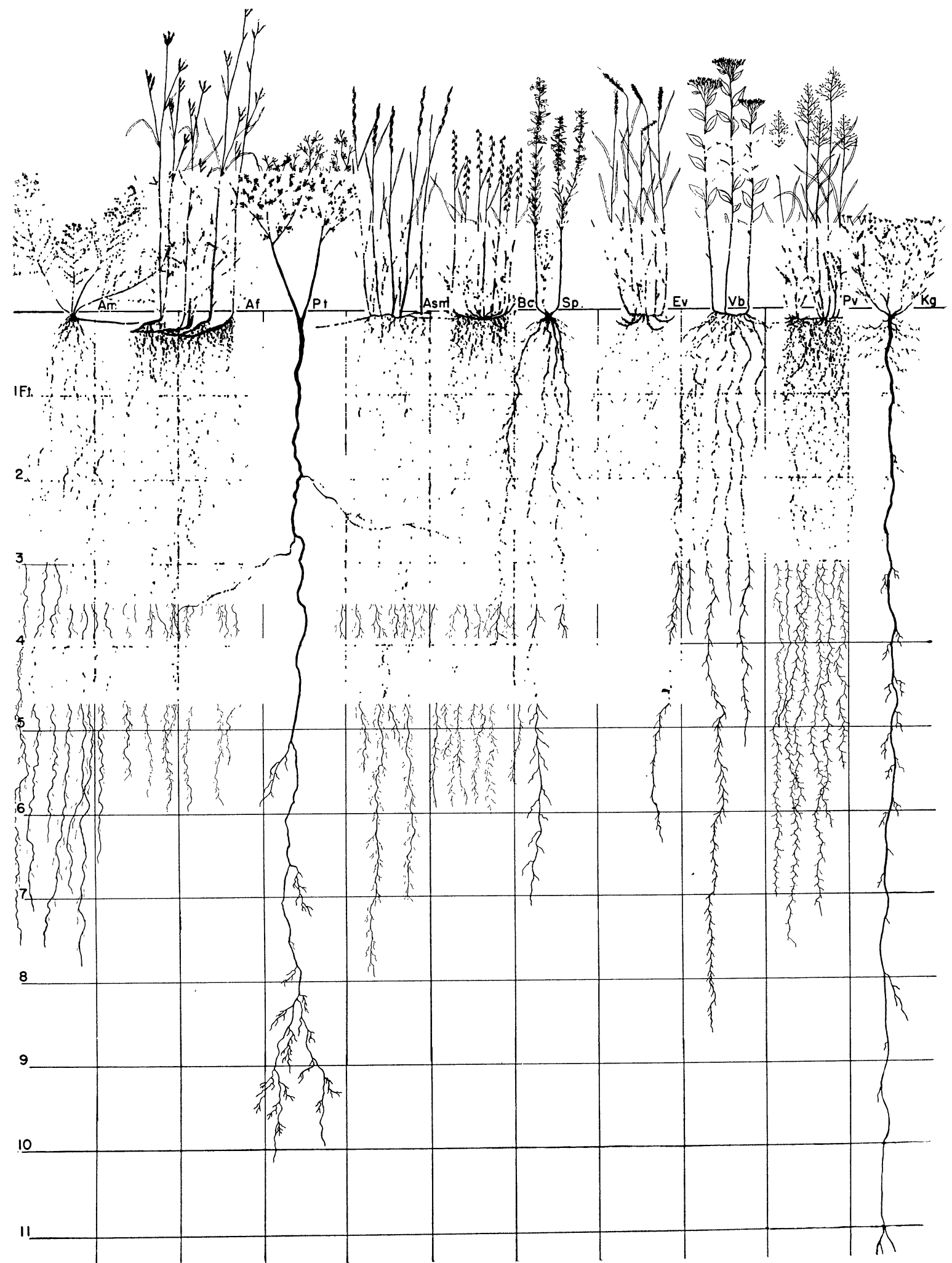

FIG. 57. Root development of native prairie plants in the big bluestem type at Hays, Kan., at the end of the great drought. Am, Aster multiflorus; Af, Andropogon furcatus; Pt, Psoralea tenuiflora; Asm, Agropyron smithii; Be, Bouteloua curtipendula; Sp, Salvia pitcheri; Ev, Elymus virginicus; Vb, Vernonia baldwini; Pv, Panicum virgatum; and $\mathrm{Kg}$, Kuhnia glutinosa. 


\section{Iowa STations iN 1940}

At the Iowa stations, where the mean annual precipitation ranged from 29.5 to 31.7 inches, rainfall during the several months was not sufficient to keep both soil and subsoil constantly moist (Fig. 58). A

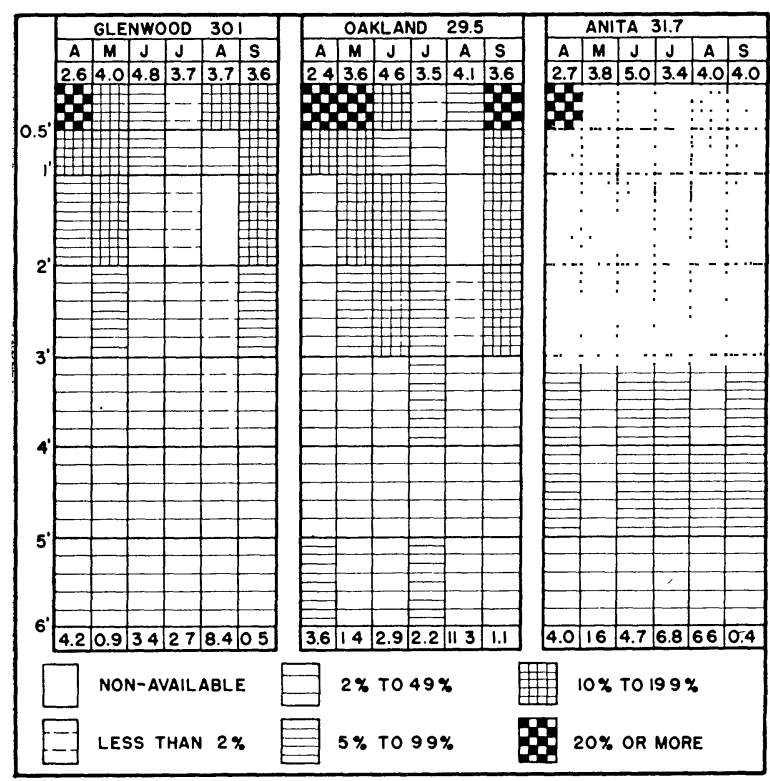

FIG. 58. Available soil moisture to a depth of 6 feet at three Iowa stations during 1940 . Mean annual precipitation at each station follows the name, mean monthly precipitation is below the letter indicating the month, and current monthly rainfall is given at the foot of each column.

constantly moist soil did prevail the previous year (Weaver and Albertson 1940), but the growing season of 1940 was characterized by midsummer drought. This was least severe at the Iowa stations where precipitation was not only highest and best distributed but also because of the ready infiltration of water into the soil which was kept in a porous, water-receptive condition by the continuous cover of bluestem grasses.

Monthly rainfall was far above the mean at all stations in April, but below normal for the remaining months except for very heavy rainfall in either July or August or during both months. Soil drought occurred at the first two stations (Fig. 58) in midsummer, and growth was distinctly retarded by temporary unavailability of water in the first or second foot. ${ }^{4}$ Available soil moisture in the third foot (and fourth foot at Glenwood) was reduced to less than 2 percent. This greatly affected the yield of vegetation (Table 13).

The low yield of the first clipping at Anita was the result of a late spring prairie fire. Otherwise, yields at this station were consistently high. At the other stations they were somewhat lower in July and decreased greatly in August. The midsummer drought

4 Total water content of soil minus the hygroscopic coefficient (which was determined for each soil depth at each station) is designated as water available for growth. The hygroscopic coefficient, with few exceptions, ranged between 9.1 and 11.9 percent.
TABLE 13. Monthly and total yield in grams of grasses and forbs at each of the Iowa stations in 1940, and total production of controls.

\begin{tabular}{|c|c|c|c|c|c|c|}
\hline \multirow[b]{2}{*}{ Date } & \multicolumn{2}{|c|}{ Glenwood } & \multicolumn{2}{|c|}{ Oakland } & \multicolumn{2}{|c|}{ Anita } \\
\hline & Grasses & Forbs & Grasses & Forbs & Grasses & Forbs \\
\hline June $6 \ldots$ & 2,881 & 502 & 2,577 & 444 & 1,668 & 230 \\
\hline July $5 \ldots$ & 1,661 & 173 & 1,366 & 245 & 1,872 & 89 \\
\hline Aug. 6. & 546 & 63 & $4 \Sigma 9$ & 39 & 1,253 & 29 \\
\hline Sept. 1. & 1,200 & 26 & 1,088 & 61 & 889 & 10 \\
\hline Total. & 6,288 & 764 & 5,460 & 789 & 5,682 & 358 \\
\hline Controls.... & 6,355 & 874 & 5,475 & 1,118 & 4,980 & 679 \\
\hline Total clippings... & \multicolumn{2}{|c|}{7,052} & \multicolumn{2}{|c|}{6,249} & \multicolumn{2}{|c|}{6,040} \\
\hline Total controls. & \multicolumn{2}{|c|}{7,229} & \multicolumn{2}{|c|}{6,593} & \multicolumn{2}{|c|}{5,659} \\
\hline
\end{tabular}

was not pronounced at Anita, but at Glenwood the tops of the deeply rooted big bluestem were dry by July 18 and those of little bluestem appeared as if killed by frost. Only the lower one third to one half of this grass remained green. Forbs were affected but little. The grasses were even more greatly injured at Oakland. Here on level upland, both big and little bluestem appeared as if scorched. They had lost their normal color and were two-thirds dry. Forbs alone were green. Renewed growth following the abnormally high August rainfall produced a heavy yield in September. The ability of grasses to revive when rains come is a chief adaptation to semiarid climates. It is of much significance that vegetation in the clipped plots, where decreased transpiring surface had prevented great water losses, remained green and continued growth, despite exhaustion of soil moisture elsewhere.

Total yield of grasses was remarkably uniform at the three stations. There was greater variability in yield of grasses among these stations where a single harvest was made in September. The mature crop in September yielded more grass at two stations than did the total of the four clippings. But it was less at Anita where the late spring burning occurred (cf. Aldous 1934).

Early yields of forbs were high but after a second clipping they decreased greatly (Table 13). Yield of forbs was always greater, of course, where they were unclipped, since clipping is far more injurious to them than to the grasses. The chief forbs were Amorpha canescens, Euphorbia corollata, and Kuhnia glutinosa although many others occurred. Forbs supplied 14 percent of the total yield of hay in September but only 10 percent when clipped four times. Whether clipped four times or only once per season, the total average yield was practically the same-6,494 grams from the areas sampled or 1.45 tons per acre. This, however, was much greater than in the drier soil westward. Results from elippings at the Iowa prairies are given in Table 13.

\section{Lincoln Stations in 1940}

At the Lincoln stations the mean annual precipitation ranged between 26.2 and 27.9 inches. The 
current monthly rainfall at all stations, with few exceptions, was lower and often very much lower than the mean. The only significant increase above the mean was about 2 inches in August at Belleville. Severe midsummer and late summer drought occurred at all stations (Fig. 59).

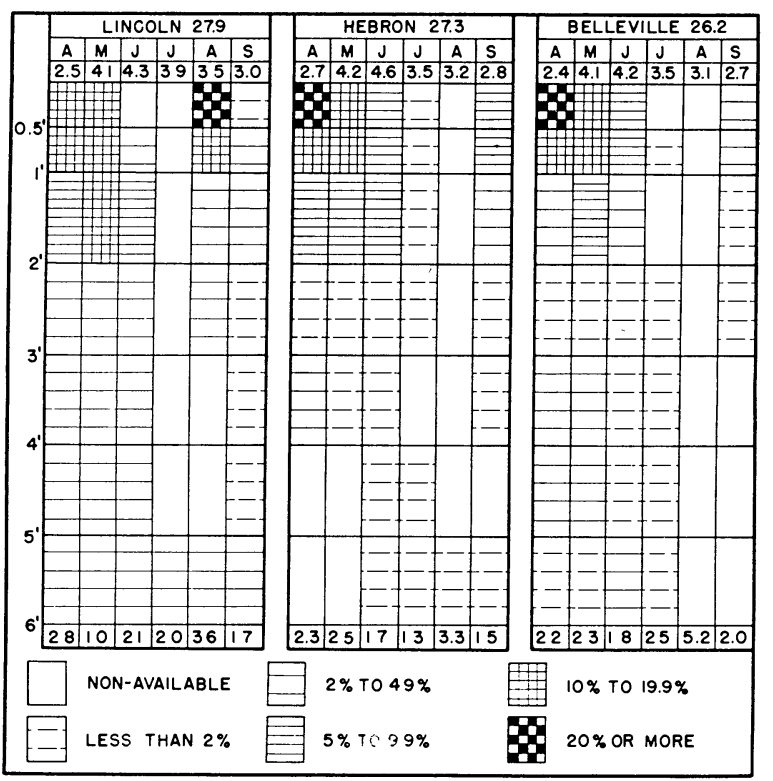

F1G. 59. Available water content of soil, mean annual and mean monthly precipitation, and current monthly precipitation at the Nebraska-Kansas bluestem stations in 1940.

The early growing season was cool and sufficiently moist to promote a good growth of grasses. At Lincoln drought threatened after the middle of May, but although precipitation in June was light, the showers were so distributed that the vegetation made a good growth until late in the month. Then it not only wilted but was greatly damaged by severe drought. The green color of the grasses practically disappeared and the bluestems turned reddish brown as they normally do in October. When trod upon, the grasses crunched like snow. This condition prevailed at all three stations in July. Although the drought at Hebron and Belleville began a little later, it prevailed somewhat longer than at Lincoln, where more than 4.2 inches of rain fell between July 26 and August 4. Here, and after heavy rains at the other stations, growth was renewed (except some plants which had died) and much foliage developed. It was believed that the prairies would be mowed at Hebron and Belleville, hence the controls also were harvested on July 30. At Lincoln they were in a protected area and were left intact until September, when the other controls were harvested for a second time.

Yields of grasses were highest at Lincoln, where a considerable amount of the early growing needle grass was intermixed with the bluestems (Table 14). The July 1 yield exceeded the earlier one at Hebron, where the prairie had been burned, but was con-
TABLE 14. Monthly and total yield in grams of grasses and forbs at each of the Nebraska-Kansas bluestem stations in 1940, and total production of controls.

\begin{tabular}{|c|c|c|c|c|c|c|}
\hline \multirow{2}{*}{ Date } & \multicolumn{2}{|c|}{ Linccln } & \multicolumn{2}{|c|}{ Hebron } & \multicolumn{2}{|c|}{ Belleville } \\
\hline & Grasses & Forbs & Grasses & Forbs & Grasses & For'ss \\
\hline June $1 \ldots \ldots$ & 1,591 & 230 & 671 & 74 & 1,143 & 32 \\
\hline July $1 \ldots$ & 916 & 40 & 708 & 67 & 635 & 102 \\
\hline Aug. $1 \ldots$ & 57 & 14 & 0 & 0 & 150 & 7 \\
\hline Sept. 1 & 2,055 & 70 & 1,644 & 19 & 1,232 & 13 \\
\hline Total.... & 4,619 & 354 & 3,023 & 160 & 3,160 & 154 \\
\hline Controls July 30. & & & 1,324 & 160 & 1,900 & 44 \\
\hline Sept. 1 & 4,303 & 284 & 1,288 & 60 & 1,371 & \\
\hline Total.......... & 4,303 & 284 & 2,612 & 220 & 3,271 & 55 \\
\hline Total clippings... & \multicolumn{2}{|c|}{4,973} & \multicolumn{2}{|c|}{3,183} & \multicolumn{2}{|c|}{3,314} \\
\hline Total controls... & \multicolumn{2}{|c|}{4,587} & \multicolumn{2}{|c|}{2,832} & \multicolumn{2}{|c|}{3,326} \\
\hline
\end{tabular}

siderably reduced at the other stations. On August 1 , there was no grass to harvest at Hebron and very little elsewhere. September 1 clippings were the heaviest of the season at all stations, the yield at Hebron being larger than that at Belleville. Total yields of clippings were relatively high despite the midseason drought. They were highest at Lincoln and about the same at the other stations (Table 14). Forbs, with one exception, yielded most at the first clipping. The chief species were Amorpha canescens, Aster multiflorus, and Liatris punctata.

The total of the four clippings averaged less than the single harvest at Belleville. The average total clipping at the three stations yielded 3,823 grams, the control yields weighed 3,582. The yield of controls was only 0.80 ton per acre and only 55 percent of that at the Iowa stations.

\section{Carleton Stations in 1940}

At the Carleton stations the mean annual precipitation (25.0 to 27.3 inches) was nearly as great as that at two of the Lincoln stations near which they occur (Fig. 60). The great difference lay in the fact that the vegetation had been much more damaged by drought and that relic bluestems had succumbed to the invasion of dense stands of western wheat grass. Precipitation was below normal and nearly always much less than normal, except in April at Montrose and in August at Carleton (Fig. 60). The wheat grass greatly decreased water infiltration and the soil was practically without available water after early summer, except as temporarily moistened by light showers. The grass dried in June without producing spikes. At two of the three stations the wheat grass depended entirely upon the moisture in the surface 2 feet of soil. Water from the deeper soil was apparently removed only by the relic, deeply rooted, xeric forbs which survived the drought because of this deeply rooting habit.

The rolling of the leaves of wheat grass was evidence that water was scarce as early as May 10, and 


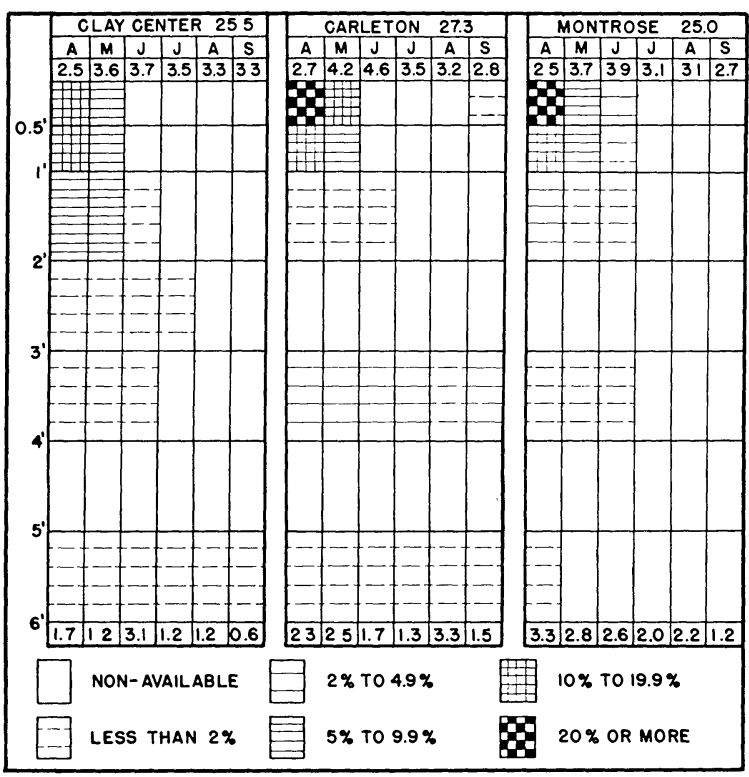

FIG. 60. Mean annual and mean monthly precipitation, current monthly rainfall, and available soil moisture at Nebraska-Kansas wheat grass stations in 1940.

drought became severe by the end of May, when this grass, over one fifth of the prairie at Carleton, was dried and had no green color. Gradually, after a period of wilting and bleaching, the whole prairie appeared tan or yellowish in color and the dried leaves and stems were brittle. The sparse forbs were dwarfed and wilted and many died. The prairie was a sea of dried grasses about 10 inches high and remained thus throughout the summer. There were no seasonal aspects except the prevernal. Only rarely did one of the widely spaced forbs bloom. Conditions were only slightly better at Montrose and somewhat worse at Clay Center, where the vegetation was lightly sprinkled with dust. No late summer development occurred at Clay Center, so meager was the rainfall. But a little growth of, wheat grass and side-oats grama occurred at the other stations after the showers in August.

The yield in May was heavy at all stations and especially at Montrose where rainfall was highest, owing to the early awakening of the wheat grass and its rapid development (Table 15). Yield decreased sharply in June. There was none or practically none in July, and only a very light yield, if any, in September. This yield, of course, was made by the utilization of rainfall between the periods of soil sampling (Fig. 60).

Other grasses, mostly side-oats grama and blue grama, were of very minor importance, all yielding heaviest in May and September except at Clay Center. Most of the forbs died, especially following the invasion of wheat grass, and the forb increment of yield was low. This was true also of the weeds which grew at Clay Center.

Total yields of wheat grass varied widely, from 1,645 to 3,507 grams. They were least at Carleton
TABLE 15. Monthly and total yield in grams of grasses and forbs at each of the western wheat grass stations, and total production of controls in 1940 .

\begin{tabular}{|c|c|c|c|c|c|c|c|c|c|c|}
\hline \multirow[b]{2}{*}{ Date } & \multicolumn{4}{|c|}{ Clay Center } & \multicolumn{3}{|c|}{ Carlaton } & \multicolumn{3}{|c|}{ Montrose } \\
\hline & 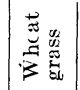 & 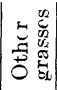 & $\begin{array}{l}n \\
\frac{n}{5} \\
5 \\
5\end{array}$ & 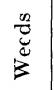 & 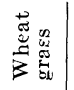 & 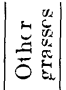 & $\stackrel{\infty}{\leftrightarrows}$ & 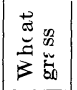 & 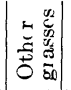 & 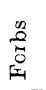 \\
\hline May 31. & 1,758 & 19 & 68 & 27 & 1,436 & 30 & 16 & 3,385 & 60 & 12 \\
\hline June 30 . & 244 & 26 & 51 & 15 & 185 & 8 & 3 & 25 & 2 & 1 \\
\hline July 31. & 0 & 0 & 16 & 4 & 0 & 0 & 5 & 12 & 2 & 0 \\
\hline Sept. 3 . & 0 & 0 & 0 & 0 & 24 & 110 & 7 & 85 & 143 & 2 \\
\hline Total. & 2,002 & 45 & 135 & 46 & 1,645 & 148 & 31 & 3,507 & 207 & 15 \\
\hline Controls. & 2,740 & 23 & 25 & $11^{\prime}$ & 1,645 & 182 & 179 & 2,625 & 16 & 91 \\
\hline $\begin{array}{l}\text { Total } \\
\text { clippings. }\end{array}$ & \multicolumn{4}{|c|}{2,228} & \multicolumn{3}{|c|}{1,824} & \multicolumn{3}{|c|}{3,729} \\
\hline $\begin{array}{l}\text { Total yields } \\
\text { of controls... }\end{array}$ & \multicolumn{4}{|c|}{2,799} & \multicolumn{3}{|c|}{2,006} & \multicolumn{3}{|c|}{2,732} \\
\hline
\end{tabular}

where the grass absorbed almost entirely from the surface foot of soil and greatest at Montrose where rainfall and soil moisture were likewise greatest. Other grasses also yielded highest at Montrose.

Total yields of clippings were in the same sequence as yields of the dominant grass. Yield of wheat grass from the control plots clipped but once was the same as the sum of the several clippings at Carleton, 738 grams greater at Clay Center, but 882 grams less at Montrose. Total yields of the controls were more uniform for the several stations than were the sums of the several elippings. They were higher, however, but in the same sequence as before, except at Montrose.

Average total clippings at the several stations yielded 2,594 grams; weight of the controls was 2,512 grams. Yield of controls was only 0.56 ton per acre and only 39 percent of that at the Iowa stations, but 70 percent of the yield from the Lincoln bluestem group.

\section{Western Kansas Stations in 1940}

At the western Kansas stations, mean annual precipitation varied from 18.9 to 23.3 inches, thus being about 2 to 8 inches lower than that at the Carleton group of prairies. The current monthly precipitation was far below normal at all stations, except in July and August at Hays, being normal at Phillipsburg in August, and much above the mean at Dighton in May and August (Fig. 61). The mixed prairie had been almost completely reduced, either by drought alone (Phillipsburg) or by long continued grazing and drought (Hays and Dighton), to a short-grass plains disclimax. On each prairie enough silt had been deposited as dust to seal the soil so effectively that runoff was greatly increased. It was further accelerated by the sparse cover of grasses and consequent lack of much obstruction to running water. For example, a 4-inch rain at Hays in July moistened the soil to only 10 to 15 inches. More usually in this arid climate a high monthly rainfall results from 


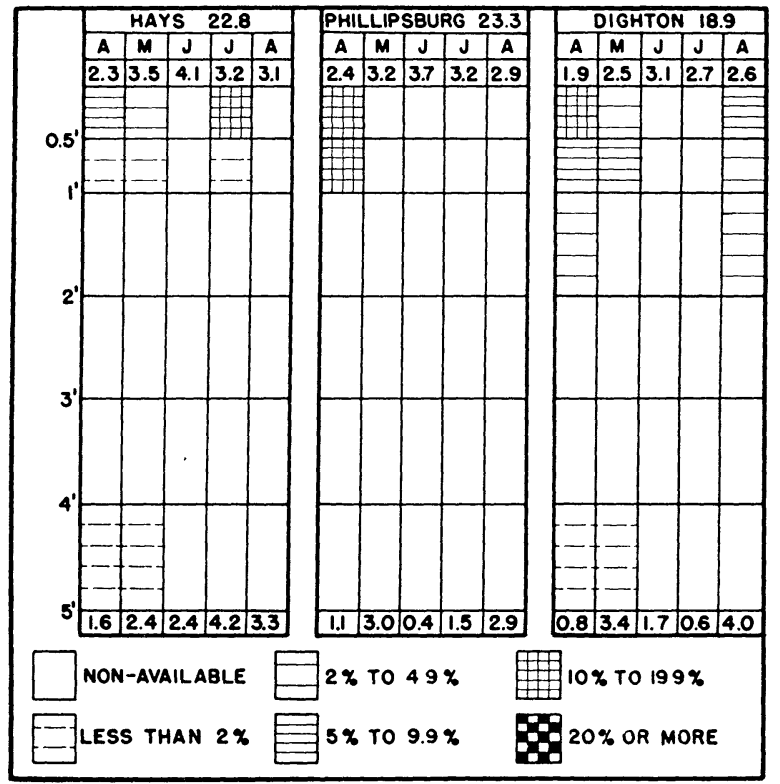

FIg. 61. Chart showing the light current monthly rainfall and small amounts of water available for growth of vegetation at the stations in western Kansas in 1940.

many small showers followed by bright sunshine and high winds; hence the water is soon lost from the soil by evaporation and relief from drought is slight and temporary.

It should be emphasized that blue grama and buffalo grass have the ability to renew growth during the warm season at any time showers provide available water and to become dormant again within a short period of time. Various weeds also start growth promptly and develop vigorously during these intermittent periods with moist surface soil, which monthly soil sampling may not reveal. In fact, weekly sampling at Hays in 1940 and 1941 showed this was the condition.

Not only was the vegetation clipped closer to the soil at these stations, about 0.5 inch, but the clippings were made at irregular intervals. The object was to harvest at such times as to obtain the total yield without the loss of any vegetation. For example, only the weeds were clipped in the plots at Hays and Dighton early in June in order to obtain the erop of Lepidium densiflorum, Monolepis nuttalliana, Lappula spp., and Hordeum pusillum, which had completed growth, produced seed, and were drying. For the same reason single autumnal elippings of controls were not made.

Drought began early in May at all of the prairies. Although rainfall varied considerably at the different stations, conditions on the prairie at Phillipsburg, which gave an intermediate yield of both grasses and weeds, will illustrate the intensity of the drought. By June 20 conditions were almost tragic. The bluishgray color of the scattered blue grama indicated severe drought. Little growth had been attained by the sparse native grasses and forbs, although weeds were so plentiful that the yield even from these stunted plants was high. The rolled and twisted leaves of the short grasses did not exceed 3 inches in length. Of the mid-grasses, side-oats grama had not renewed growth, and the wilted shoots of sand dropseed were few. The abundant weeds-species of Lappula and Lepidium, Hordeum pusillum, Sophia multifida, Plantago purshii, and Salsola pestiferwere extremely small and wilted. The few native forbs were much dwarfed; Opuntia humifusa was wilted and had put forth no new branches. Even by July 31 , there had been a very meager growth. Only a few short, wilted shoots were found in any tuft of grass. Weeds had produced less forage than the grasses. The profound drought was scarcely relieved by showers until August. By mid-September, growth was complete for the season, since all new vegetation was dry and half dead.

Yield of clippings in Table 16 shows the response measured in dry weight production. Except for weeds, it was very meager.

TABLE 16. Monthly and total yield in grams of grasses, forbs, and weeds at the short-grass prairie stations in west-central Kansas and total production in 1940.

\begin{tabular}{|c|c|c|c|c|c|c|c|c|c|c|c|}
\hline \multirow[b]{2}{*}{ Date } & \multicolumn{3}{|c|}{$\mathrm{H}_{\mathrm{AYS}}$} & \multirow[b]{2}{*}{ Date } & \multicolumn{4}{|c|}{ Phillipsburg } & \multirow[b]{2}{*}{ Date } & \multicolumn{2}{|c|}{ DightoN } \\
\hline & 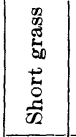 & $\begin{array}{c}0 \\
\frac{0}{Z} \\
0 \\
x_{1}\end{array}$ & 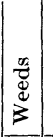 & & 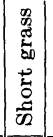 & 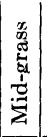 & की & $\begin{array}{l}\frac{\infty}{0} \\
\frac{0}{0} \\
3\end{array}$ & & 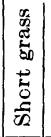 & 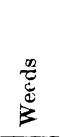 \\
\hline $\begin{array}{ll}\text { June } & 10 \\
\text { June } & 21 \\
\text { July } & 29 \\
\text { Oct. } & 2\end{array}$ & $\begin{array}{l}\ldots \\
346 \\
420 \\
452\end{array}$ & $\begin{array}{r}\ldots \\
9 \\
2 \\
\ldots\end{array}$ & $\begin{array}{r}982 \\
\ldots \\
3 \\
\ldots\end{array}$ & $\begin{array}{ll}\text { June } & 20 \\
\text { July } & 31 \\
\text { Sept. } & 17\end{array}$ & $\begin{array}{r}124 \\
193 \\
55\end{array}$ & $\begin{array}{r}8 \\
13 \\
11\end{array}$ & $\begin{array}{c}114 \\
\ldots \\
25\end{array}$ & $\begin{array}{r}1,707 \\
195 \\
63\end{array}$ & $\begin{array}{l}\text { June 11 } \\
\text { June 25 } \\
\text { Aug. 1 } \\
\text { Sept. 28 }\end{array}$ & $\begin{array}{r}\ldots \\
25 \\
33 \\
184\end{array}$ & $\begin{array}{l}3,210 \\
\ldots \ldots \\
\ldots \ldots \\
\ldots \ldots\end{array}$ \\
\hline Total.. & 1,218 & & 985 & & 372 & 32 & 139 & 1,965 & & $242:$ & 3,210 \\
\hline $\begin{array}{l}\text { Total } \\
\text { clippings }\end{array}$ & & 214 & & & & &, 508 & & & & 452 \\
\hline
\end{tabular}

The greatest yield of short grasses was at Hays, where the October harvest of grasses was highest, a result of the late summer rains. Three fourths of the yield at Dighton also resulted from rains in August and September. But at Phillipsburg both precipitation and yield in late summer were less. A few relic mid-grasses, mostly side-oats grama, occurred at Phillipsburg. Native forbs were important only at Phillipsburg; none occurred at Dighton. Dighton, however, ranked first in production of weeds and total yield of clippings as a consequence. Phillipsburg was intermediate in both respects, and Hays, although it had the most grass, gave the lowest total yields.

Average yield, 2,725 grams per sampling area or 0.61 ton per acre, is higher than that at the Carleton stations. But when yields of grasses alone are compared, the short-grass stations produced only 26 percent as much as the wheat grass stations and only 11 percent as much as the Iowa stations. 


\section{Comparison of Yields}

Yields of the several clippings of grasses and forbs, including weeds, and yields of the controls at each station group are shown in Table 17. Figure 70

TABLE 17. Summary table of plant production in grams (in round numbers) at the several stations in 1940.

\begin{tabular}{|c|c|c|c|c|c|c|c|c|}
\hline \multirow{2}{*}{ Yield } & \multicolumn{2}{|c|}{$\underset{\text { Stations }}{\text { Iowa }}$} & \multicolumn{2}{|c|}{$\begin{array}{l}\text { Western } \\
\text { Bluestem } \\
\text { Stations }\end{array}$} & \multicolumn{2}{|c|}{$\begin{array}{c}\text { Wheat } \\
\text { Grass } \\
\text { Stations }\end{array}$} & \multicolumn{2}{|c|}{$\begin{array}{l}\text { Midwestern } \\
\text { Kansas } \\
\text { Stations }\end{array}$} \\
\hline & 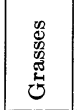 & 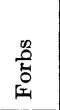 & 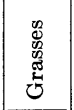 & $\frac{0}{0}$ & 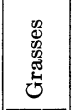 & 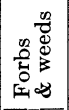 & 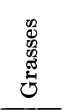 & $\begin{array}{l}\frac{0}{0} \\
0 \\
0 \\
0 \\
0 \\
0 \\
0 \\
1 \\
1\end{array}$ \\
\hline Clippings... . & 5,810 & 637 & 3,601 & 223 & 2,518 & 76 & 621 & 2,104 \\
\hline Controls... & 5,603 & 890 & 3,395 & 186 & 2,410 & 102 & $\ldots$ & \\
\hline Total Clippings. . & \multicolumn{2}{|c|}{6,447} & \multicolumn{2}{|c|}{3,823} & \multicolumn{2}{|c|}{2,594} & \multicolumn{2}{|c|}{2,725} \\
\hline Total Controls... & \multicolumn{2}{|c|}{6,494} & \multicolumn{2}{|c|}{3,582} & \multicolumn{2}{|c|}{2,512} & \multicolumn{2}{|c|}{$\ldots \ldots$} \\
\hline
\end{tabular}

shows graphically the yield of grasses and native forbs and total yields from the control quadrats where growth was not interrupted by clipping. Examination of these data shows that in 1940 production of grasses decreased directly and greatly from east to west, with corresponding increase in severity of drought. Decrease in yield of native forbs was similar to that of the grasses until the overwhelming. crops of weeds were included at the mixed prairie stations. In fact, the weed factor was so great as to upset the very pronounced differences in yield of grass, so that total production in mixed prairie was also higher than at the wheat grass stations.

\section{Relative Height Growth at Times of Clipping}

The recovery of plants from elipping and the height attained at the time of the next elipping are of considerable significance. They are not closely connected with soil moisture as shown in the charts for unclipped prairie, since the repeated removal of the tops in itself greatly reduced water absorption and thus conserved the water supply. The removal of the cover even to a height of 1.5 inches, as in grazing, promoted loss of water directly from the soil surface, especially where there was a dearth of litter (R. J. Weaver, 1941). The results are of interest both in regard to rate of regeneration and in reproducing a stand of forage under conditions simulating grazing (Weaver and Hougen 1939).

Height growth of bluestems was progressively slightly less at the Iowa stations with the progress of the season (Table 18). At the second group of bluestem stations, height growth was more uniform but only about two thirds as great early in the summer. It was increased by rains late in summer. An average difference of 6 inches in height of foliage of unclipped big bluestem at the two groups of stations correlates with decrease in water content of soil westward.

The low stature of wheat grass, 10 to 12 inches as compared with a normal height of 30 to 36 inches,
TABLE 18. Average heights in inches of grasses and a representative forb at the several stations at each clipping, and average heights of control vegetation when clipped in September.

\begin{tabular}{c|c|c|c|c|c|c}
\hline \hline $\begin{array}{c}\text { Station } \\
\text { groups }\end{array}$ & Species & June & July & Aug. & Sept. & $\begin{array}{c}\text { Con- } \\
\text { trols }\end{array}$ \\
\cline { 2 - 6 } Iowa...... & Bluestems........ & 11 & 9 & 7 & 7 & 16 \\
Lincoln.... & Bluestems ........ & 6 & 6 & 6 & 8 & 10 \\
Carleton... & Wheat grass...... & 12 & 4.5 & $\ldots$ & 5 & 10 \\
\hline Iowa...... & A morpha canescens & 9 & 6 & 6 & 3 & 19 \\
Lincoln.... & A morpha canescens & 4 & 5 & 4 & 3 & 7 \\
Carleton... & Amorpha canescens & 3 & 3 & 3 & 2 & 5 \\
\hline
\end{tabular}

reflects extreme drought. Recovery after clipping: was slight and the measurements in July and September represent only a few plants. Times of eutting of short grasses at the western stations were too irregular for comparisons of height growth.

Amorpha canescens was selected to represent the forbs because it was the only species found in most prairies in each of the station groups, because it often occurred in great abundance, and because of its ability to recover regularly after clipping. Nearly all forbs renewed growth to some degree in the moist Iowa prairies, but recovery was less uniform in the Lincoln group, and in the dry soils at the wheat grass stations many forbs did not grow after the first clipping.

\section{Soil Moisture and Plant Growth in 1941}

The growing season of 1941 was characterized by a late, wet spring and abundant rainfall in May, June, and July or at least during one or two of these months. The greatest increase in rainfall occurred at the stations in Kansas, where the normal monthly precipitation in June of 3 to 4 inches increased at some stations to 10 or 11 inches. At the shortgrass stations, total rainfall for April or May or June was at least twice normal. Vegetation flourished until late summer when moderate drought occurred.

Water content of soil was high to a depth 5 or 6 feet at both Glenwood and Oakland until early in August (Fig. 62). Soil moisture and yields at Anita are not given because of accidental spring burning which depressed growth. The very heavy rains in June added moisture to the deep subsoil and greatly ameliorated conditions of growth when water content was depleted in August, especially at Glenwood. Hence development was not much retarded. The foliage of little and big bluestem attained an average height of 16 and 24 inches, respectively (Fig. 63).

At the Lincoln group of stations both rainfall and soil moisture were less than in Iowa, but the general pattern of water distribution was the same (Fig. 64). Conditions of growth were poorest at Lincoln, since the 11 inches of rainfall in June at Hebron and Belleville did not occur there. But they were more favorable than during 1940, despite the severe drought during July and August, which eaused the vegetation to wilt and dry. 


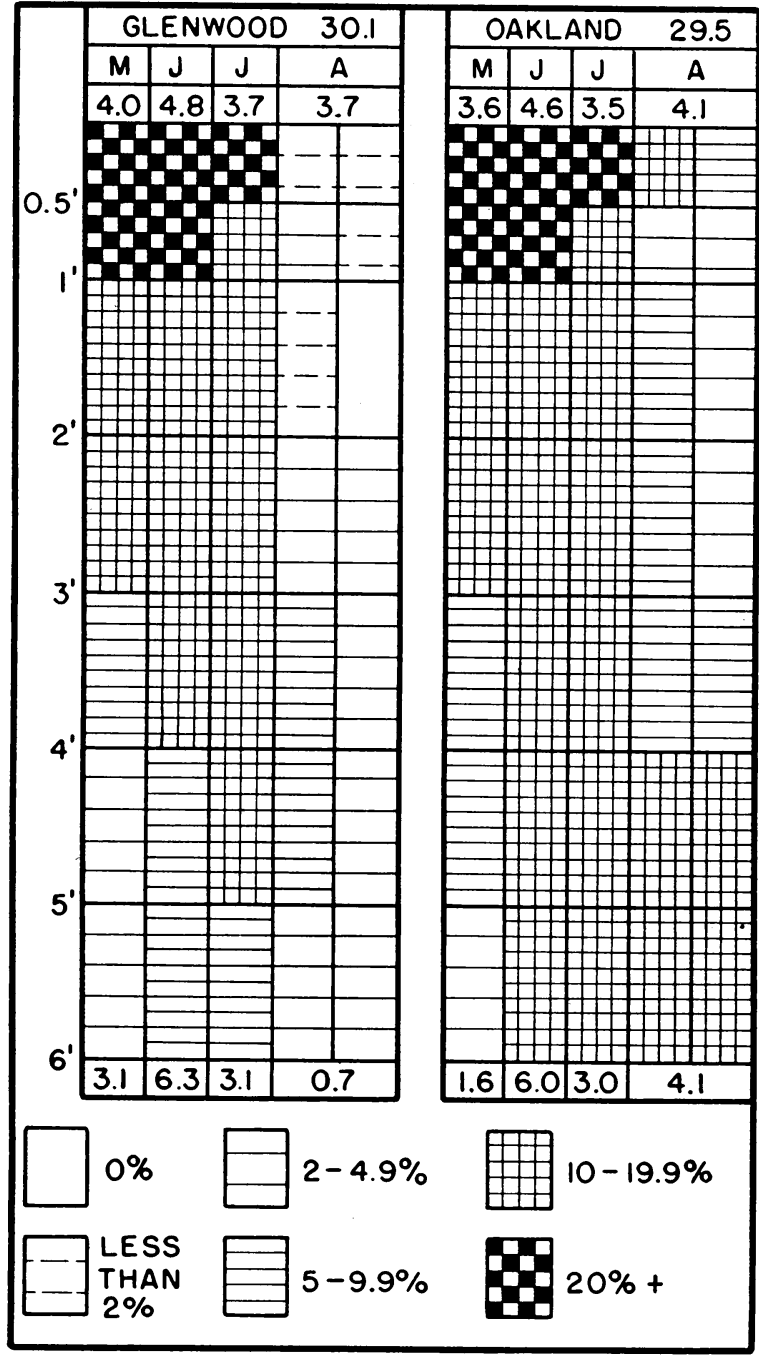

FIg. 62. Available soil moisture and precipitation at two. Iowa stations during 1941.

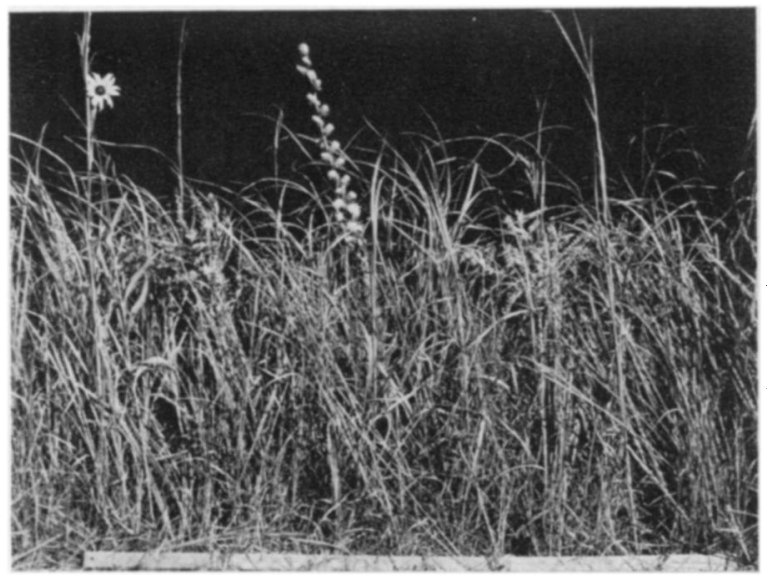

Fig. 63. Representative dense growth of grasses and forbs at the Iowa stations in 1941. The grasses averaged 20 inches in height on September 1.

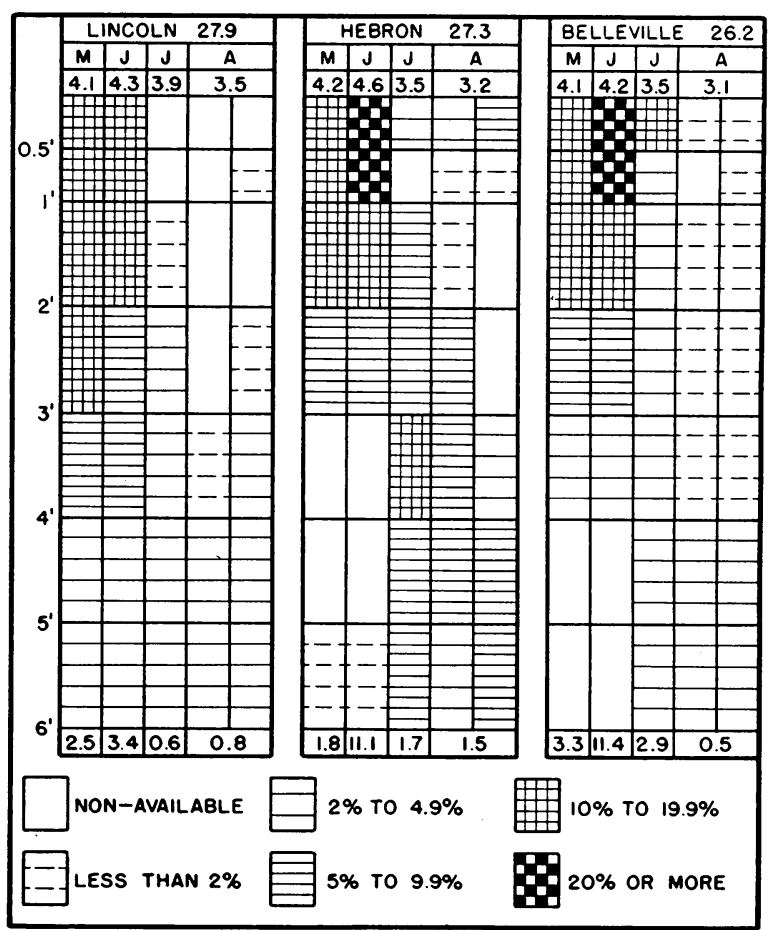

Fig. 64. Available water content of soil, mean annual and mean monthly precipitation, and current monthly precipitation at the Nebraska-Kansas bluestem stations in 1941.

Production of foliage was not much retarded at Hebron or Belleville, although the tops of the grasses had dried (Fig. 65). Foliage of little and big bluestem attained heights of 12 and 16 inches, respectively, which was 4 and 8 inches less than in Iowa.

At the western wheat grass stations, total summer precipitation was usually somewhat lower than at the preceding group, except Lincoln which had the lowest rainfall. Soil moisture was also considerably

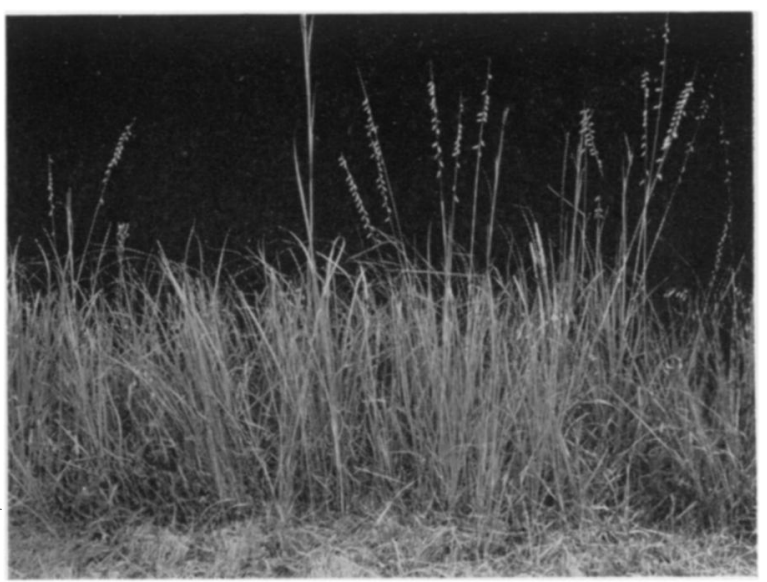

FIG. 65. Representative growth of bluestems and sideoats grama at Hebron, Neb. Height of bluestems was about 15 inches on August 27, 1941. 
lower, as may be seen by even a casual comparison of Figures 64 and 66. This resulted in part from poorer infiltration of water and from the early absorption of soil moisture by a large crop of western wheat grass. Since this grass matures early, deficiency of subsoil moisture and even late summer drought had little effect in decreasing yields. Even by the first of May the foliage was 10 inches high and in the fourth-leaf stage. By the end of June the foliage level averaged 18 inches and the spikes, which were 3.5 to 5 inches long, were held on slender stalks 12 to 18 inches above the leaves. $A$ view of the wheat grass prairie was as monotonous as that of a

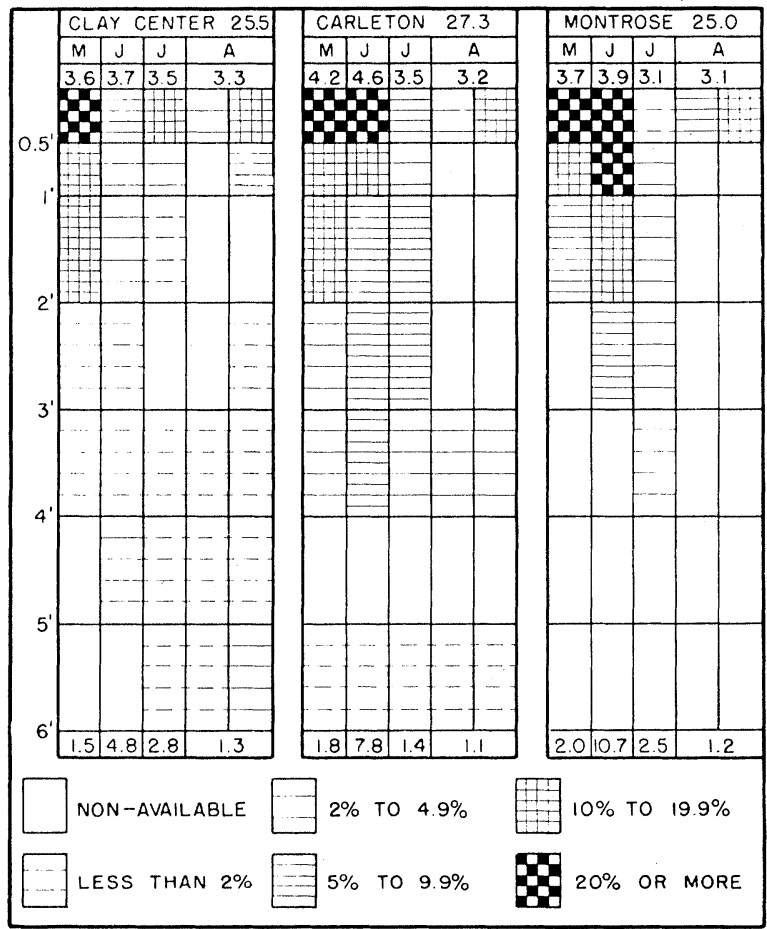

Fig. 66. Available soil moisture and precipitation at the Nebraska-Kansas wheat grass stations in 1941.

field of wheat. Above the foliage level each stalk bore only 1 short leaf. Submerged within this sea of grass (30 to 36 inches tall) were the few relic grasses and dwarfed forbs. Amorpha canescens, which averaged 24 inches in height in Iowa and 17 inches at the other bluestem stations, was here only 8 inches tall. Yield of hay was large (Fig. 67).

At the short-grass stations the previous years of drought had so depleted the native grasses and forbs that there were few to benefit by the excellent water supply in 1941 (Figs. 68 and 69). Moreover, at Phillipsburg and Hays, as generally throughout the area, a very early dense cover of Hordeum pusillum resulted from seed which had germinated the preceding fall. This weed grew to heights of 12 to 20 inches and quickly overtopped all of the remaining native vegetation. By shading it, development was greatly retarded, as was shown by the long, slender, light-green tillers of blue grama and stolons of

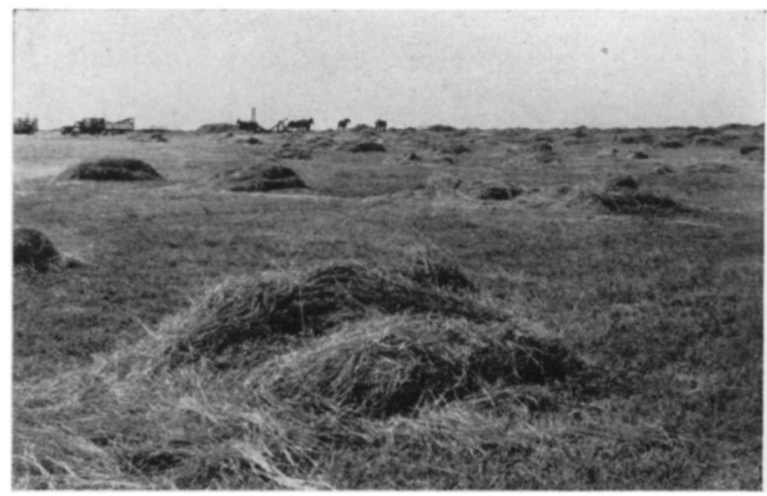

FIG. 67. View in the Carleton prairie on August 26 showing the large amount of hay produced in 1941 .

buffalo grass. Even the pistillate flowers of buffalo grass were borne on long, slender flower stalks. There were numerous other weeds, as in 1940, which grew vigorously except where they were held in check by little barley. Among the most important were Panicum capillare, Salsola pestifer, Amaranthus graecizans, Lepidium densiflorum, Lappula occidentalis, Monolepis nuttalliana, and Plantago purshii. Where weeds were less abundant, as at Dighton, the short grasses were tillering profusely or spreading rapidly by stolons, but very few seedlings were found here or elsewhere (cf. Weaver and Mueller 1942). The best growth and recovery of the grasses occurred where weeds were absent, as at Dighton where patches of soil were completely revegetated by autumn. A few native forbs renewed growth at the other stations, but no forbs were found in the plots at Dighton. Mid-grasses, not found at Dighton, if alive had commonly only a few green tillers protruding from the periphery of the dry bunches.

By midsummer the matured little barley had, at a distance, the color and appearance of a ripened field of grain. Although dead, its shade still retarded growth of the short grasses. The most abundant

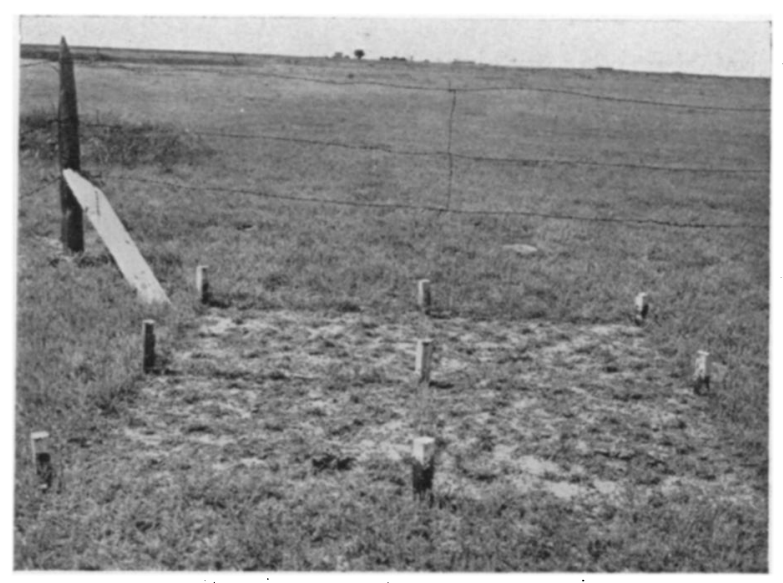

Fig. 68. One of the five 4-square-meter areas from which yields were obtained at Dighton, Kan. The short vegetation, consisting mostly of peppergrass, has just been clipped, showing much bare soil. June 25,1940 . 


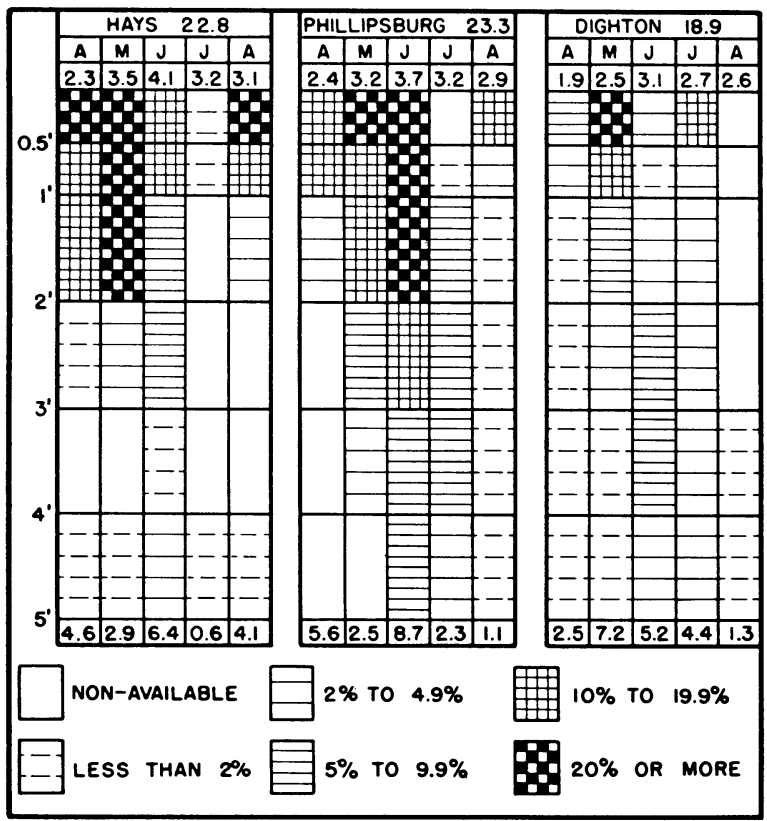

FIG. 69. Available soil moisture and precipitation at the Kansas short-grass stations in 1941.

forb was the very drought-resistant Malvastrum coccineum; a few other formerly common species, as Astragalus mollissimus, were observed for the first time in several years.

There was a short midsummer drought at Hays and Phillipsburg (and a little later at Dighton) when the short grasses became dormant, and cactus seedlings dried. But this was of relatively short duration and vegetation grew late into the autumn.

\section{YIELDS IN 1941}

Although only total yields are recorded from the western Kansas stations in order to conform with those from the other stations, they are from clippings made at various intervals. Only three were made at Dighton where weeds were few, but an additional earlier one on May 30 at the other stations was necessary to obtain the dead little barley and certain other weeds which might otherwise have been lost. Drought ended the growing season by September 13 at Dighton but the final harvest was made on October 18 at Hays (Table 19).

Yields of grasses and forbs at the Iowa stations were high and quite uniform. The average yield of the forbs was 15.7 percent of that of the grasses. The total average yield of hay was 10,912 grams per area sampled or 2.43 tons per acre.

Despite the midsummer drought at Lincoln, yields of grasses and forbs were only 16 percent less than at the other two bluestem stations in the Lincoln group. Average yield of forbs was 11.3 percent of that of the grasses. Total average yield of forage was 8,283 grams per area sampled or 1.85 tons per acre.

Yield of wheat grass was highest at Montrose and about 31 percent less at Clay Center, where it was
TABLE 19. Annual yield in grams of grasses and forbs at the several stations in 1941 and average annual yield per station group.

\begin{tabular}{|c|c|c|c|c|c|}
\hline 1941 & Oahland & Glenwood & Lincoln & Hebron & Belleville \\
\hline Grasses. & 9,902 & 8,956 & 6,609 & 8,030 & 7,685 \\
\hline Forbs.... & 1,264 & 1,701 & 732 & 698 & 1,096 \\
\hline Total........ & 11,166 & 10,657 & 7,341 & 8,728 & 8,781 \\
\hline Average..... & \multicolumn{2}{|c|}{10,912} & \multicolumn{3}{|c|}{8,283} \\
\hline \multicolumn{2}{|l|}{1941} & Clay Center & \multicolumn{2}{|c|}{ Carleton } & Montrose \\
\hline \multirow{2}{*}{\multicolumn{2}{|c|}{ Wheat grass. . }} & \multirow{2}{*}{8,547} & \multicolumn{2}{|c|}{9,752} & 12,422 \\
\hline \multirow{2}{*}{\multicolumn{2}{|c|}{ Forbs ........ }} & & \multicolumn{2}{|c|}{1,091} & 45 \\
\hline & & $\begin{array}{l}142 \\
471\end{array}$ & & 32 & \\
\hline \multicolumn{2}{|l|}{ Weeds. . } & 1,528 & \multicolumn{2}{|c|}{$\ldots \ldots$} & $\ldots \ldots$ \\
\hline \multicolumn{2}{|l|}{ Total.......... } & 10,688 & \multicolumn{2}{|c|}{10,875} & 12,467 \\
\hline \multicolumn{2}{|l|}{ Average. } & \multicolumn{4}{|c|}{11,343} \\
\hline \multicolumn{2}{|l|}{1941} & Hays & \multicolumn{2}{|c|}{ Phillipsburg } & Dighton \\
\hline \multirow{2}{*}{\multicolumn{2}{|c|}{$\begin{array}{l}\text { Short grasses. . . . . . . . } \\
\text { Mid-grasses ......... }\end{array}$}} & \multirow[t]{2}{*}{2,086} & & 4,171 \\
\hline & & & \multicolumn{2}{|c|}{329} & $\ldots \ldots$ \\
\hline \multicolumn{2}{|l|}{ Forbs........... } & 159 & & 571 & \\
\hline \multicolumn{2}{|l|}{ Weeds... } & 4,677 & \multicolumn{2}{|c|}{7,572} & 243 \\
\hline \multicolumn{2}{|l|}{ Total.... } & 6,922 & 10 , & 585 & 4,414 \\
\hline Average. & & & & 307 & \\
\hline
\end{tabular}

least. This is in direct accord with the amount of precipitation from February to June, which was about 18 and 11.5 inches at the two stations, respectively. Soil at both stations was dry to 6 feet in depth the preceding autumn. Yields of other grasses (mostly side-oats grama) were small, except at Carleton. Weeds were of considerable importance in the more open wheat grass stand at Clay Center where they composed 14 percent of the forage (Table 19). Total yields at the three stations were not so variable as those of wheat grass alone, since the weeds, forbs, and other grasses at Clay Center increased the total yield of hay to 98 percent of that at Carleton.

The average total yield of grasses, 10,666 grams, was 13 percent greater than that of the bluestems in Iowa and 43 percent greater than that of the grasses at the other bluestem stations. Quality, however, was greatly inferior. Native forbs constituted only 1.5 percent of the total yield. Average total yield was 11,343 grams per area sampled or 2.53 tons per acre.

At the mixed prairie stations yields of short grass slightly exceeded 2,000 grams at two stations but were nearly twice as great at Dighton. Mid-grasses occurred only at Phillipsburg, but in a small amount, being outranked by native forbs. Unlike the preceding year, relatively few weeds grew at Dighton but their yield at the other stations was two to nearly four times as great as the grasses. It is of interest that the station with the lowest total yield had the best cover of grass. 
Average total vields of grasses in grams at the several station groups were 9,429 in Iowa, 7,441 at the second bluestem group, 10,666 at the wheat grass prairies where stems of wheat grass added greatly to weight of forage, but only 2,900 grams at the mixed prairie stations.

Relative yields of grasses, native forbs and weeds, and average total yields of 1940 are shown together with similar vields in 1941 in Figure 70. The yields

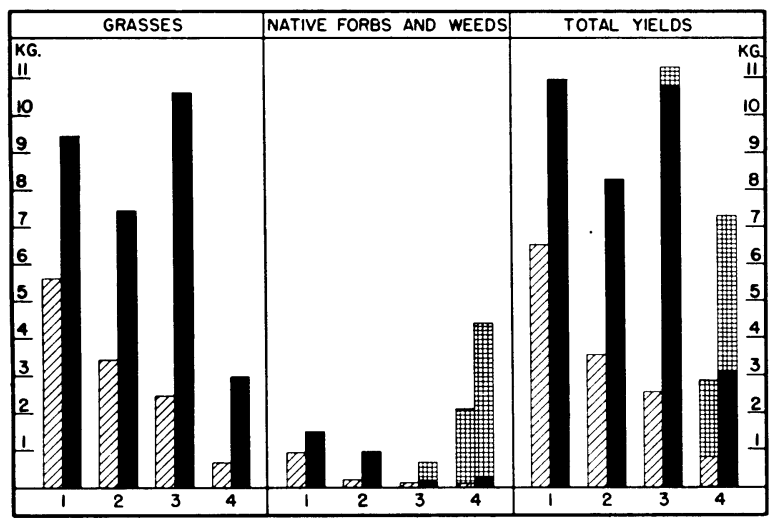

Fig. 70. Average yields of grasses, native forbs and weeds, and total yields of forage in 1940 and 1941 at the Iowa stations (columns 1), Lincoln stations (2), western wheat grass stations (3), and mixed prairie stations (4). Left hateh is for 1940 ; black for 1941 ; crosshatch indicates weeds.

of grasses increased at all stations during 1941. Increase in Iowa over the preceding year (columns 1) was 68 percent and at the Nebraska-Kansas bluestem stations 119 percent. Yield of western wheat grass was more than four times as great in 1941, as was also the yield of short grasses. In tons per acre, yields in 1941 were $2.10,1.66,2.38$, and 0.65 , respectively, from Iowa westward.

Yields of forbs increased but in a smaller degree; a large crop of weeds was produced in the short grass (columns 4) in 1940 but this was doubled in 1941.

Total yields were highest at the Nebraska wheat grass stations where weeds are included with the coarse-stemmed wheat grass. But when the economic criteria of quality of forage and actual utilization are applied, the value of the crop was greatest in Iowa each vear and decreased regularly westward to the short-grass disclimax.

\section{Atmospheric Drought}

Evaporation has long been used as an index in which the factors of insolation, humidity, temperature, and wind movement are more or less integrated. Data on relative evaporation losses as measured by the Weather Bureau at Lincoln and Hays are given for 1940 and 1941 in Table 20.

The data in Table 20 reveal two important facts: (1) that eraporation stress was higher each month at Lincoln in 1941 than during 1940; and (2) that, except in October, 1941, evaporation at Hays was always much higher than at Lincoln.
TABLE 20. Evaporation losses in inches from a free water surface as measured by the Weather Bureau at Lincoln, Nebraska, and Hays, Kansas.

\begin{tabular}{c|c|c|c|c|c|c|c|c|c}
\hline \hline Year & Station & Apr. & May & June & July & Aug. & Sept. & Oct. & Total \\
\hline $1940 \ldots$ & Lincoln .. & 3.57 & 5.11 & 7.04 & 8.87 & 4.77 & 4.38 & 3.09 & 36.83 \\
$1940 \ldots$ & Hays . . & 8.45 & 11.25 & 13.87 & 16.88 & 10.32 & 9.23 & 7.45 & 77.45 \\
\hline $1941 \ldots$ & Lincoln . & 4.44 & 6.21 & 8.41 & 11.42 & 6.15 & 5.82 & 4.58 & 47.04 \\
$1941 \ldots$ & Hays . . & 6.31 & 9.01 & 10.07 & 13.16 & 12.24 & 11.02 & 4.45 & 66.26 \\
\hline
\end{tabular}

Atmospheric drought usually accompanies soil drought but it has probably been only a secondary cause of retarded growth. Even during the years of 1934, 1936, and 1939, when losses were greatest, it seems clear that high temperatures in grasslands were not the direct cause of death of plants, but one of the several factors which intensified drought. Evidence from both field and control experiments fully support this view (Weaver and Albertson 1940; Weaver and Mueller 1942). High evaporation rates nearly always accompany high temperatures in this midcontinental grassland. But only when the water supply of the soil has been depleted to low levels does high water loss through transpiration have much retarding effect upon growth of native plants in the field. They are adjusted to wide ranges of insolation, temperature, humidity, and wind. In general, these are all of greater magnitude, except for an inverse relation in relative humidity, progressively from Iowa to western Kansas.

To attempt to correlate plant production closely with any one or any combination of these factors would not be advisable under post-drought conditions of a plant cover, which is in itself extremely variable. The correlation between plant production at any group of stations during the dry year (1940) and the wetter one (1941) yields definite values. Likewise, a comparison of vields from areas of higher rainfall with those of lower precipitation, when studied in the light of change of types of vegetation and relative depletion of cover, is of great value in a quantitative interpretation of drought.

\section{SUMMARY}

A resurvey of vegetation both above and below ground was made in midwestern grasslands at the end of the great drought. It included the western portion of the true prairie in Iowa, eastern Nebraska and Kansas, and the mixed prairie, with its shortgrass disclimax, in western Kansas and Colorado. Five prairies in western Iowa, 12 in true prairie west of the Missouri River, and 12 in mixed prairie in Kansas have been studied year by year since the inception of drought in 1933-1934. This is the record of their condition in 1940 near the end of the drought.

There was little damage to native vegetation east of the Missouri River. Elsewhere in true prairie Andropogon scoparius, which was formerly the most abundant upland grass, suffered the greatest loss. It entirely disappeared from many prairies, and was 
reduced from about 55 percent basal cover to 5 percent elsewhere. A. furcatus, after heavy initial losses, has persisted or spread widely. Its percentage relation to the total remaining but often sparse cover is about the same as formerly. Sorghastrum nutans has all but disappeared from uplands and there is now less on lowlands than before the dry years.

Poa pratensis, formerly widely and uniformly scattered throughout, almost all died in pastures and drought-stricken prairies. Although absent from most prairies, in others it is plentiful in ravines and on less xeric slopes.

Stipa spartea withstood the drought well, and a continuous spread of this grass has taken place into bared or semibared areas regardless of slope, and even onto low ground. Sporobolus heterolepis, like needle grass, did not occur in some prairies. $\mathrm{Al}$ though early losses from drought were high, such great increase has occurred that it is now often ten times more abundant than formerly.

Bouteloua curtipendula is so drought-resistant that it often persisted where all other mid-grasses succumbed. Formerly constituting only 1 percent of the prairie cover, it has increased so greatly almost everywhere that it now ranks as the second most important prairie grass.

Agropyron smithii has made a phenomenal increase from a species of very minor importance to one of first rank. This early growing, sod-forming grass alone has complete control over thousands of acres of grassland. During drought, nearly all other grasses failed to grow successfully in association with western wheat grass.

Bouteloua gracilis, formerly of very limited and local occurrence in true prairie, was harmed by desiccation the least of all species. It has spread so widely that patches can be found anywhere except where the original cover of mid-grasses persisted. Buchloe dactyloides formerly occurred even less frequently than the preceding short grass, but it has made good gains in those prairies where it was found. Both grasses have commonly intermixed with western wheat grass.

Grasses of less importance that have lost heavily include Koeleria cristata, Panicum scribnerianum, and $P$. wilcoxianum. Sporobolus asper and Muhlenbergia cuspidata have increased in abundance.

From a study of large numbers of quadrats before, during, and near the end of the drought, the percentage of basal cover of each species was calculated and these data were used as a quantitative basis for comparing gains or losses.

The seven most important grasses in true prairie in 1940 in order of their abundance were Agropyron smithii, Bouteloua curtipendula, Andropogon furcatus, Stipa spartea, Bouteloua gracilis, Sporobolus heterolepis, and Andropogon scoparius.

Three types of grassland occur in mixed prairie. The short-grass disclimax type is widely distributed over level or moderately rolling uplands. The little bluestem type is found on hillsides with rock outcrops and in shallow ravines. The postclimax, big bluestem type covers the lower slopes and deep ravines.

Andropogon scoparius has entirely disappeared from the short grass, and has been reduced in its own type from about 45 to 1 per cent. $A$. furcatus was reduced to about one fourth its former amount in the little bluestem type. In its own type, about four fifths of it was replaced by more xeric grasses.

Bouteloua curtipendula almost disappeared from the short-grass type, it made steady gains in territory left bare by the death of little bluestem, and in ravines and on lowlands it frequently replaced big bluestem. Species of Aristida disappeared from the short-grass type and suffered a high rate of mortality elsewhere.

Bouteloua gracilis and Buchloe dactyloides formerly constituted four fifths of the entire vegetation of the short-grass type. Extreme drought and burial by dust killed most of the short grasses. In contrast to these losses, which ranged from 50 to 100 percent of the cover, gains were made by blue grama spreading on hillsides and into ravines where mid-grasses had succumbed. Most lowlands also became more or less covered with short grasses.

Buchloe dactyloides formerly shared the area more or less equally with blue grama. In many places it entirely disappeared and nearly everywhere it was heavily damaged. Despite rapid and repeated local recovery, this species lost much more heavily than the more stable blue grama. The present, much depleted short-grass cover consists almost entirely of these two species, but buffalo grass constitutes probably not more than one third of the mixture.

Studies of numerous permanent quadrats in 1932 and 1940 revealed the increase or decrease of each perennial grass in the three types of mixed prairie. Bouteloua gracilis and Buchloe dactyloides are the species of major importance in the short-grass type. In the other types they are Bouteloua curtipendula, Agropyron smithii, Bouteloua gracilis, Buchloe dactyloides, Andropogon furcatus, and Sporobolus asper var. hookeri.

A comprehensive record of the weakening and death of forbs shows that their decrease was not gradual but sporadic, corresponding with the severity of drought. Many shallowly rooted plants were nearly all killed the first year; more deeply rooted ones often persisted for several years; some very deeply rooted forbs lost most heavily near the end of the drought.

Average number of long-lived native forbs found before the drought in bluestem prairies in Iowa, in Nebraska and Kansas, and in wheat grass prairies in Nebraska and Kansas was 85, 50, and 38, respectively. At the end of the drought it was, in the same order, 82, 41, and 21.

Relative size of the same species decreased greatly with increasing drought westward. Amorpha canescens decreased in height from 19 inches to 7 and then to 5 inches, and Rosa arkansana from 30 to 18 and finally to 6 inches. 
Decrease or increase in abundance of forbs was ascertained from lists made before, during, and at the end of the drought. In a list each species was placed in one of 5 classes according to its abundance and ecological importance. In the Nebraska-Kansas true prairie, only 1 species increased in abundance at all stations, 11 changed but little, and 19 decreased considerably. In western wheat grass, 13 species disappeared entirely.

Species and ratings of long-lived forbs found at the end of the drought were ascertained for the undisturbed bluestem prairies in Iowa, the drought-depleted ones in Nebraska and Kansas, and the Nebraska-Kansas wheat grass prairies. Fifty-nine species of the more mesic forbs were found at the Iowa prairies only. Thirty-six species of more xeric forbs occurred at the more westerly bluestem prairies as well. Another group of 34 xeric species was found in the wheat grass prairies.

Only 17 species of native perennial forbs were found at the 15 stations in mixed prairie. Only one or two were abundant in any prairie. Ten of the most drought-resistant occurred sparingly before 1939 , but thereafter only four.

Number of stems of forbs in two circles, 50 feet in diameter, was ascertained at each station. Average number of stems at the Iowa stations was 27,875 , at the Nebraska-Kansas bluestem stations 7,109, and at the wheat grass stations only 1,083. At 14 stations in western Kansas, the average number of stems per unit area was only 23.

Occurrence and abundance of the most important long-lived forbs of uplands in 1940 are shown schematically. Only 5 species maintained approximately their predrought abundance; 41 species decreased in abundance. All maintained their usual abundance in Iowa, and all but 5 decreased in eastern Kansas and Nebraska. Among species mostly of mixed prairie and short-grass disclimax, 28 are listed. Three persisted in normal numbers, 14 disappeared, and the rest lost heavily. Another group of 13 species increased greatly in abundance during drought somewhere in true prairie or mixed prairie.

Grasses and forbs in true prairie died from desiccation in 1934-1936 only after they had absorbed the available water in the surface 3 or 4 feet of soil. Rainfall during the dry years was inadequate to moisten the deeper portion of this dry layer. Roots of new vegetation were confined to that portion of the soil moistened by current precipitation, and they were separated by a dry layer from the moist subsoil.

Loss of the plant cover greatly hindered water infiltration as did also the covering of dust, and the invasion of Agropyron smithii. The period necessary for an inch of water to infiltrate into bare soil was 2.8 times as long as that for infiltration into the same kind of soil which supported a good cover of predrought prairie grasses.

Resurvey of root systems in true prairie involved an examination of (1) relic grasslands where the original plant population was little affected above ground, of (2) badly denuded areas where only widely scattered relic or invading grasses occurred, and of (3) half-bared places where relic grasses or invading species had increased.

Root habits were normal under the first condition. Under the second, much space between the plants was almost free from living roots. Depth of roots corresponded with that of current rainfall penetration, about 2 to 2.5 feet.

Roots of relic Andropogon furcatus were confined to the surface 2.5 feet and those of invading Agropyron smithii to about 2 feet. Below, a dry layer of soil with water unavailable for growth extended to about 5 feet. Certain forbs with roots only 5 to 6 feet deep had succumbed, but others which had penetrated to depths of 10 to 17 feet before the drought survived, although greatly dwarfed. They obtained water in part from a slightly moist subsoil that had not received additional moisture since 1934 .

In mixed prairie, bisects in the upland short-grass type revealed that roots of Bouteloua gracilis and Buchloe dactyloides were fewer in number and shallower in depth of penetration. A former root depth of 4 to 5 feet at Hays, Kansas, had been replaced by one of about 18 inches. Under lighter precipitation westward, the depth was rarely more than 12 inches. Most old roots of forbs had died. The few that grew during the drought were much shallower.

In ravines where additional water was supplied by runoff so that the deep soil was moist, the roots grew deeper as drought increased. The roots of Andropogon furcatus, Agropyron smithii, and certain other grasses extended a foot deeper and branched more profusely in the deeper soil than in 1933. Those of Aster multiflorus, Vernonia baldwini, and other coarse forbs doubled their length.

Amount of available soil moisture and yield of grasses and forbs were ascertained at four groups of stations during the dry year 1940, and the moderately wet one 1941 .

In 1940 at the western Iowa stations, rainfall was sufficient to keep the soil continuously moist to a depth of 6 feet, except for a moderate midsummer drought. Three bluestem prairies, undamaged by former drought, gave a high and uniform yield of grasses. Yield from one clipping in September was about the same as the sum of four elippings on sample areas of similar size made at monthly intervals. Early yields of forbs were high, but after a second clipping, they decreased greatly. Total yield of forage was 1.45 tons per acre.

In the drought-damaged bluestem prairies westward, severe drought began in midsummer and available soil moisture was exhausted to a depth of 5 or 6 feet. Yield was about the same whether obtained in one or four harvests. It was only 0.80 ton per acre or 55 percent of that in Iowa.

Where western wheat grass had replaced the bluestems, soil moisture was available only in spring and early summer. Yield in May was heavy but light or none thereafter. Yield of four clippings and of a 
single harvest were nearly equal. Total yield was only 0.56 ton per acre or 39 percent of that in Iowa.

In western Kansas where drought and dust had reduced the basal cover of the short grasses to only 10 percent normal, drought began in May. Usually the surface foot alone had available water; but only temporarily and at widely separated intervals. Average yield, including weeds, was 0.61 ton per acre. Yield of grasses and native forbs alone was only 13 percent as great as that in Iowa.

In 1941 in Iowa, water content was high to a depth of 6 feet at least until August, and vegetation flourished. At the second group of stations, both rainfall and soil moisture were less, but the general pattern of water distribution was the same, with moderate drought in late summer. Heavy rainfall at the wheat grass stations resulted in an abundance of soil moisture, at least until the wheat grass had ripened. An excellent supply of soil moisture prevailed at the Kansas short-grass stations. It promoted a rank growth of Hordeum pusillum and other weeds which greatly retarded the development of the much depleted native grasses.

Average yield in Iowa was 2.43 tons per acre, of which the native forbs produced about 16 percent. The Nebraska-Kansas bluestem prairies yielded 1.85 tons per acre, about 11 percent being native forbs. Yield at the wheat grass stations was 2.53 tons per acre, of which 1.5 percent was supplied by the native forbs. This was 4.5 times as great as the yield of the preceding year, and slightly greater than that in Iowa. Yield of native grasses at the short-grass stations was only 0.65 ton per acre; that of grasses and weeds together was 1.63 tons.

\section{LITERATURE CITED}

Albertson, F. W. 1937. Ecology of mixed prairie in west central Kansas. Ecol. Monog. 7: 481-547.

1938. Prairie studies in west central Kansas. Kan. Acad. Sci. Trans. 41 : 77-83.

1939. Prairie studies in west central Kansas. Kan. Acad. Sci. Trans. 42 : 97-107.

1941. Prairie studies in west central Kansas. Kan. Acad. Sei. Trans. 44 : 48-5̃

Albertson, F. W., \& J. E. Weaver. 1942. History of the native vegetation of western Kansas during seven years of continuous drought. Ecol. Monog. 12: 23-51.

Aldous, A. E. 1934. The effect of burning on Kansas bluestem pastures. Kan. Agr. Coll. Expt. Sta., Tech. Bul. 38.

Clements, F. E., \& R. W. Chaney. 1937. Environment and life in the Great Plains. Carnegie Inst. Wash., Suppl. Pub. 24.

Duley, F. L. 1939. Surface factors affecting the rate of intake of water by soils. Soil Sci. Soc. Am. Proc. 4: $60-64$

Duley, F. L., \& L. L. Kelly. 1939. Effect of soil type, slope, and surface conditions on intake of water. Neb. Agr. Coll. Expt. St., Res. Bul. 112.

Fowler, R. L., \& J. E. Weaver. 1940. Occurrence of a disease of side-oats grama. Bul. Torrey Bot. Club. 67: $503-508$.
Kellogg, C. E. 1936. Development and significance of the great soil groups of the United States. U. S. Dept. Agr., Misc. Pub. 229.

Kramer, J., \& J. E. Weaver. 1936. Relative efficiency of roots and tops of plants in protecting the soil from erosion. Univ. Nebr. Cons. and Surv. Div. Bul. 12.

Lowdermilk, W. C. 1930. Influence of forest litter on run-off, percolation, and erosion. Jour. Forestry 28: 474-491.

Mueller, I. M., \& J. E. Weaver. 1942. Relative drought resistance of seedlings of dominant prairie grasses. Ecology 23 : $387-398$.

Pavlychenko, T. K. 1941. Root systems of certain forage crops in relation to the management of agricultural soils. Doctorate Thesis, Univ. Nebr. In press.

Robertson, J. H. 1939. A quantitative study of trueprairie vegetation after three years of extreme drought. Eeol. Monog. 9: 431-492.

Savage, D. A. 1937. Drought survival of native grass species in the central and southern Great Plains, 1935. U. S. Dept. Agr. Tech. Bul. 549.

Shantz, H. L. 1911. Natural vegetation as an indicator of the capabilities of land for crop production in the Great Plains area. U. S. Dept. Agr., Bur. Plant Ind. Bul. 201.

Sperry, T. M. 1935. Root systems in Illinois prairie. Ecology 16: 178-202.

Weaver, J. E. 1915. A study of the root systems of prairie plants of southeastern Washington. The Plant World 18: 227-248; 273-292.

1917. A study of the vegetation of southeastern Washington and adjacent Idaho. Univ. Nebr. Studies 17: 1-133.

1919. Ecological relations of roots. Carnegie Inst. Wash., Pub. 286.

1920. Root development in the grassland formation. Carnegie Inst. Wash., Pub. 292.

1942. Competition of western wheat grass with relict vegetation of prairie. Amer. Jour. Bot. 29: 366-372.

Weaver, J. E., \& F. W. Albertson. 1936. Effects of the great drought on the prairies of Iowa, Nebraska, and Kansas. Ecology 17: 567-639.

1939. Major changes in grassland as a result of continued drought. Bot. Gaz. 100: 576-591.

1940. Deterioration of grassland from stability to denudation with decrease in soil moisture. Bot. Gaz. 101 : 598-624.

1940a. Deterioration of midwestern ranges. Ecology 21 : 216-236.

Weaver, J. E., \& T. J. Fitzpatrick. 1934. The prairie. Eeol. Monog. 4 : 109-295.

Weaver, J. E., \& W. W. Hansen. 1939. Increase of Sporobolus eryptandrus in pastures of eastern Nebraska. Ecology 20: 374-381.

1941. Native midwestern pastures-their origin, composition, and degeneration. Univ. Neb. Cons. and Surv. Div. Bul. 22.

1941a. Regeneration of native midwestern pastures under protection. Univ. Nebr. Cons. and Surv. Div. Bul. 23.

Weaver, J. E., \& G. W. Harmon. 1935. Quantity of living plant materials in prairie soils in relation to run-off and soil erosion. Univ. Neb. Cons. and Surv. Div. Bul. 8. 
Weaver, J. E., \& V. H. Hougen. 1939. Effect of frequent clipping on plant production in prairie and pasture. Amer. Midl. Naturalist 21: 396-414.

Weaver, J. E., \& I. M. Mueller. 1942. Role of seedlings in recovery of midwestern ranges from drought. Ecology 23: 275-294.

Weaver, J. E., \& W. C. Noll. 1935. Comparison of runoff and erosion in prairie, pasture, and cultivated land. Univ. Neb. Cons. and Surv. Div. Bul. 11.

Weaver, J. E., L. A. Stoddart, \& W. Noll. 1935. Response of the prairie to the great drought of 1934 . Ecology 16: 612-629.

Weaver, R. J. 1941. Water usage of certain native grasses in prairie and pasture. Ecology 22: 175-192. 